\title{
HOW THE COMMANDER IN CHIEF'S “CALL FOR PAPERS" VEILS A PATH DEPENDENT RESULT OF TORTURE
}

\author{
Robert Bejesky ${ }^{\dagger}$ \\ CONTENTS
}

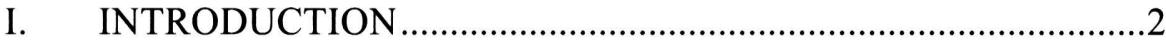

II. DENYING RESTRICTIONS ON EXECUTIVE

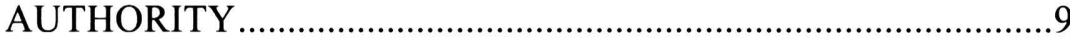

III. APPLYING INTERNATIONAL LAW TO AFGHANISTAN ....17

A. Gainsaying International Law by Factual Application..........17

B. Failed State .................................................................................18

C. International in Scope ........................................................22

D. Extraterritorial Jurisdiction .....................................................27

E. Classifying Combatants..........................................................31

1. Legal Advice …….............................................................31

2. Distinguishing Combatants .............................................33

F. Using Interrogators and Classifying Torture.........................39

1. International Law Prohibits Interrogation .......................39

2. Distinguishing Between Torture and Cruel and Inhuman Treatment .......................................................41

3. Endorsing Specific Methods ...........................................44

4. Nullifying the Relevance of Authorized Interrogation Standards with the Bybee Memo.....................................47

5. Modifying the Bybee Memo and Using "Enhanced

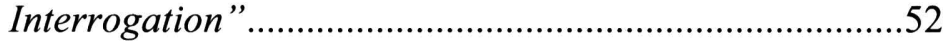

IV. A POLITICIZED ROLE WITH SECRECY ...............................57

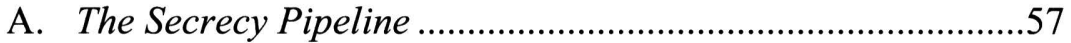

B. Using Secrecy to Hide Illegal Orders ....................................59

C. Using Secrecy to Hide Legal Advice .....................................62

$\dagger$ M.A. Political Science (Michigan), M.A. Applied Economics (Michigan), LL.M. 


\section{Using Secrecy that Compromised Military Responsibilities.}

\section{INTRODUCTION}

Path dependence and critical junctures refer to decisive choices and events that prompt future trajectories, which are difficult to reverse because the progression of the political or institutional consequence involves entrenched behavior, anteceding determinations, and an elevated cost of altering course. ${ }^{1}$ Path dependent methodology has been applied to diverse topics, such as economic behavior, party system dynamics, the incorporation of labor movements, and implementation of legislative agendas. ${ }^{2}$ This article considers how the two primal riskaverse post-9/11 assumptions - that there was a global al-Qaeda network intent on perpetrating numerous catastrophic terror attacks and that severe psychological interrogation methods were essential for prying details of plots from suspected terrorists to prevent those attacks ${ }^{3}$ -initiated a path dependent process that resulted in a rampant violation of human rights on suspected terrorists, combatants, and innocent people, both in and out of war zones. ${ }^{4}$ Residing between the two causal premises and the result was the intervening variable of advisory memos that rationalized illicit interrogation practices ${ }^{5}$ with loopholes to make

1. Ruth Berins Collier \& David Collier, Shaping the Political Arena: Critical JunCtures, the LABOR MOVEMENT, AND Regime DynAmics IN LATIN AMERICA 27-29 (2002); Paul Pierson, Increasing Returns, Path Dependence, and the Study of Politics, 94 AM. POL. SCI. REv. 251, 251-53 (2000).

2. Pierson, supra note 1, at 251-54.

3. Robert Bejesky, A Rational Choice Reflection on the Balance Among Individual Rights, Collective Security, and Threat Portrayals Between 9/11 and the Invasion of Iraq, 18 BARRY L. REV. 31, 34-43 (2012) [hereinafter Bejesky, Rational Choice Reflection]; Robert Bejesky, The Utilitarian Rational Choice of Interrogation from Historical Perspective, 58 WAYNE L. REV. 327, 330-32 (2012) [hereinafter Bejesky, Utilitarian Rational Choice].

4. Bejesky, Utilitarian Rational Choice, supra note 3, at 386-91; Robert Bejesky, Pruning Non-Derogative Human Rights Violations into an Ephemeral Shame Sanction, 58 LoY. L. REv. 821, 823-28 (2012) [hereinafter Bejesky, Pruning]; Robert Bejesky, Closing Gitmo: The Epiphany Approach to Habeas Corpus During the Military Commissions Circus, 7-10, 20-25 (unpublished manuscript) [hereinafter Bejesky, Epiphany Approach]; Elizabeth Rindskopf Parker, A National Security Agenda, 43 Suffolk U. L. Rev. 829, 835 (2010) (speaking of the Bush Administration's interrogation techniques and noting that "[c]hoices made by earlier administrations are difficult to reverse abruptly, if at all, and as a result new approaches evolve slowly.").

5. See generally Mary Ellen O'Connell, Affirming the Ban on Harsh Interrogations, 66 
legal restraints inapplicable. ${ }^{6}$

Yet if one discards the premises, signified by the reality that the first terrorist attack since 9/11 occurred at the 2013 Boston Marathon when two bombs exploded and killed three Americans and injured dozens more, ${ }^{7}$ there has been virtually no credible evidence of sleeper cells, realistic plots, or preparation for an attack, ${ }^{8}$ and that wars in Afghanistan and Iraq were not persuasively related to imminent threats inside American borders; legal advisory memoranda endowed government interrogation orders with a façade of legitimacy even as

Оніо ST. L.J. 1231 (2005); Mary Ellen O’Connell, Responses to the Ten Questions, 36 WM. Mitchell L. ReV. 5127, 5132 (2010) [hereinafter O'Connell, Responses] (stating that "the memo on the Geneva Conventions and other torture memos are replete with errors, erroneous reasoning, omissions, and illogic," and the sole plausible "explanation for the shockingly poor quality of the memos ... is that the authors intended to reach conclusions the law did not support."); see also Jordan J. Paust, Executive Plans and Authorizations to Violate International Law Concerning Treatment and Interrogation of Detainees, 43 Colum. J. Transnat'l L. 811, 855-61 (2005); Diane Marie Amann, Guantánamo, 42 Colum. J. Transnat'L L. 263, 348 (2004); Neal K. Katyal \& Laurence H. Tribe, Waging War, Deciding Guilt: Trying the Military Tribunals, 111 YALE L.J. 1259, 1260 (2002); Harold Hongju Koh, The Case Against Military Commissions, 96 AM. J. INT'L L. 337 (2002).

6. Linda M. Keller, Is Truth Serum Torture?, 20 AM. U. INT'L L. REv. 521, 551 (2005) (opining that the advice was tantamount to "the power to commit genocide, to sanction slavery, to promote apartheid, to license summary execution."); Rosa Ehrenreich Brooks, War Everywhere: Rights, National Security Law, and the Law of Armed Conflict in the Age of Terror, 153 U. PA. L. REV. 675, 682 (2004) (noting that "lawyers for the Bush administration went from the legitimate conclusion that the Geneva Conventions cannot easily be applied to many modern conflicts, to the disingenuous and flawed conclusion that there were therefore no legal constraints at all on U.S. interrogation practices.").

7. Brian Z. Tamanaha, Are We Safer from Terrorism? No, But We Can Be, 28 Y ALE L. \& POL'Y REV. 419, 419 (2010) (noting that there were no attacks on U.S. soil since 9/11); Palash R. Ghosh, Boston Marathon Bombing: A Timeline Of Terrorist Attacks on US Targets Since 9/11, INT'L BUS. TIMES (Apr. 15, 2013), available at http://www.ibtimes.com/boston-marathon-bombing-timeline-terrorist-attacks-us-targets911-1193485? $\mathrm{ft}=\mathrm{k} 82 \mathrm{~h} 2$ (last visited Nov. 18, 2013).

8. Ian S. Lustick, Fractured Fairy Tale: The War on Terror and the Emperor's New Clothes, 16 MinN. J. INT'L L. 335, 338 (2007); The Editorial Board, Indisputable Torture, N.Y. TIMES (Apr. 16, 2013), available at http://www.nytimes.com/2013/04/17/opinion/indisputable-torture-of-

prisoners.html? ref=extraordinaryrendition\&_r $=0$ (last visited Nov. 18, 2013) (stating that a recent "independent, nonpartisan panel's examination of the interrogation and detention programs" implemented by the Bush Administration found violations of international law and stated that there was "no firm or persuasive evidence that they produced valuable information that could not have been obtained by other means"); David Cole \& Jules Lobel, Are We Safer?, L.A. Times (Nov. 18, 2007), available at http://www.latimes.com/la-opcole18nov18,0,6931314.story (last visited Nov. 18, 2013) (noting that the Justice Department claimed that there were 261 "terrorism and terrorism-related" convictions, but only two cases "actually involve[ed] attempted terrorist activity."). 
U.S. integrity was undermined with widespread deprivation of human rights. ${ }^{9}$ However, it is also possible that the memoranda were not a consequential intervening cause that modified Bush Administration decision-making, but instead human rights abuses may have been the foreseeable proximate cause of White House assumptions and solicitations for advice. ${ }^{10}$ Consider the following causal flow:

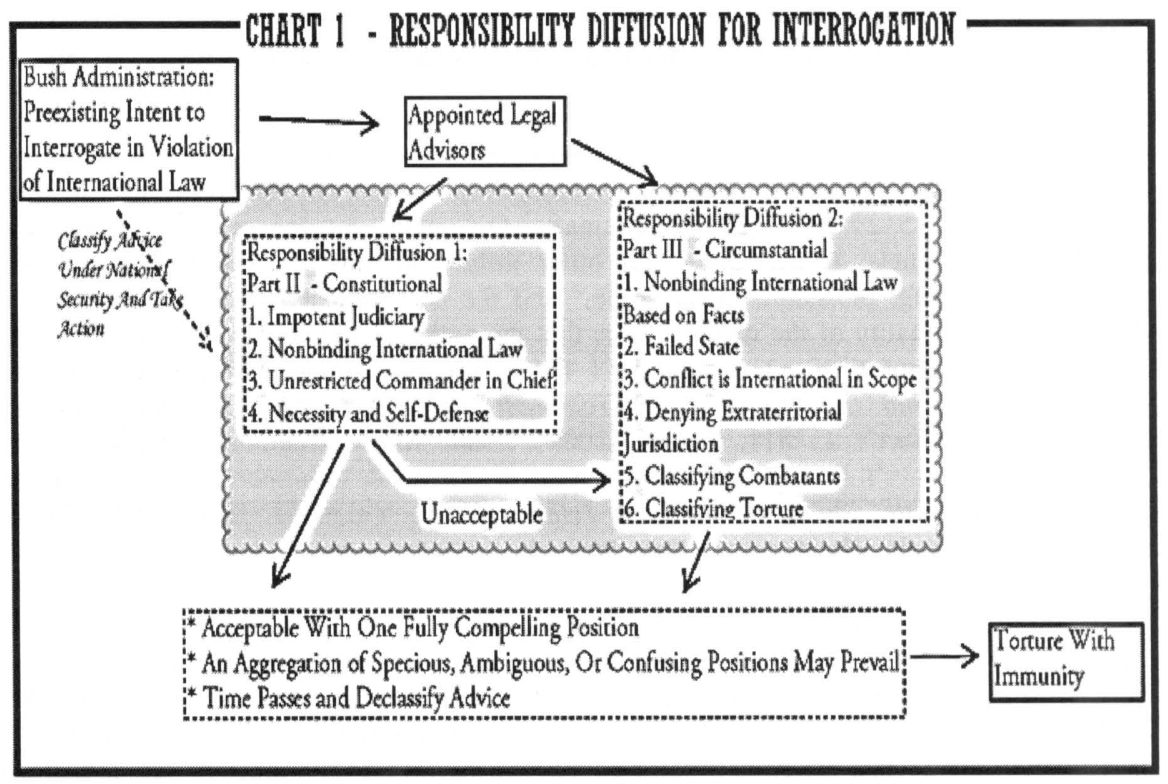

Chart 1 starts with an administration decision and request and the outcome is torture with immunity. Newsweek referenced an effective "call for papers" when it reported that President Bush petitioned White House lawyers to "find a way to exercise the full panoply of powers granted the president by Congress and the Constitution: If that meant pushing the boundaries of the law, so be

9. Bejesky, Pruning, supra note 4, at 823-28, 875-76; David Abraham, The Bush Regime from Elections to Detentions: A Moral Economy of Carl Schmitt and Human Rights, 62 U. MiAmi L. REv. 249, 249 (2008) (stating that "the Bush regime is known primarily for the international mess it has created as the world's only superpower, and for the way is has sacrificed long-accepted legal norms - military and civilian, international and domestic - in the name of its so-called War on Terror," which led to "domestic repression" and "the brutality and denial of legal obligations toward enemy non-Americans.").

10. Judith Resnick, Detention, The War on Terror, and the Federal Courts: An Essay in Honor of Henry Monaghan, 110 ColuM. L. REV. 579, 612 (2010) (stating that "[t]he Torture Memos sanctions actions that, as hundreds of pages of reports from an array of sources now document, took place."). 
it."11 Similarly finding specious that objective legal advice instigated interrogation operations, Human Rights Watch emphasized that "there is now substantial evidence that civilian leaders requested that politically appointed government lawyers create legal justifications to support abusive interrogation techniques, in the face of opposition from career legal officers." 12 In December 2008, the Senate Armed Service Committee Report explained that the solicitation "on how to use aggressive techniques, redefined the law to create the appearance of their legality, and authorized their use against detainees."13 Professor Jack Goldsmith, who was later appointed to head the Department of Justice Office of Legal Counsel (OLC) that was writing legal memoranda, stated that the Bush Administration wanted to "act aggressively and preemptively," but because officials feared prosecution, the solution required having lawyers "find some way to make what [Bush] did legal." 14

Of the thousands of attorneys in the Department of Justice and American government, the White House repeatedly summoned the same demimonde of lawyers ${ }^{15}$ who referred to themselves as the "War Council"-White House Counsel Alberto Gonzales, White House legal counsel David Addington, Department of Defense General Counsel William J. Haynes, and OLC Deputy Attorney General John Yoo. ${ }^{16}$

11. Evan Thomas, Full Speed Ahead: After 9/11, Bush and Cheney Pressed for More Power-and Got It. Now, Predictably, the Questions Begin. Behind the NSA Spying Furor, NEWSWEEK (Jan. 8, 2006, 7:00 PM), available at http://www.thedailybeast.com/newsweek/2006/01/08/full-speed-ahead.html (last visited Nov. 18, 2013).

12. Human Rights Watch, Getting Away with Torture: The Bush AdMINISTRATION AND MistrEATMENT OF DETAINEES 2 (July 2011), available at http://www.hrw.org/sites/default/files/reports/us0711webwcover_1.pdf (last visited Nov. 18, 2013).

13. Senate Armed Services Committee, Inquiry into the Treatment of DetaineES IN U.S. CUSTODY xii (2008), available at http://www.armedservices.senate.gov/Publications/EXEC\%20SUMMARY -

CONCLUSIONS_For\%20Release_12\%20December\%202008.pdf (last visited Nov. 18, 2013).

14. Dan Eggen \& Peter Baker, New Book Details Cheney's Lawyer's Efforts to Expand Executive Power, WASH. Post (Sept. 5, 2007), available at http://www.washingtonpost.com/wpdyn/content/article/2007/09/04/AR2007090402292.html (last visited Nov. 18, 2013).

15. Robert C. Power, Lawyers and the War, 34 J. Legal Prof. 39, 89-90 (2009).

16. Michael P. Scharf, The Torture Lawyers, 20 DuKE J. COMP. \& INT'L L. 389, 389, 392 (2010) (noting that advisory opinions on war-detention, and interrogation were "hijacked and dictated by a cabal of four highly placed government lawyers."); M. Cherif Bassiouni, The Institutionalization of Torture Under the Bush Administration, 37 CASE W. RES. J. INT'L L. 389, 396 (2006) (stating that Bush Administration legal advisors 
The "War Council" produced legal opinions containing highly unpopular advice and the President classified the memos under national security so that other government lawyers could not critique the consultation prior to the predetermined action being taken. ${ }^{17}$

From witness experiences, Department of Defense investigations, congressional hearings, correspondence among top officials, and court records, ${ }^{18}$ it is clear that military personnel, interrogators, and private contractors committed acts amounting to torture or inhuman treatment on detainees for several years ${ }^{19}$ with the full cognizance of Bush Administration officials. ${ }^{20}$ While top policymakers reportedly discarded some of the legal advice, ${ }^{21}$ the damage still resulted in abuses that were condemned by Republicans, Democrats, ${ }^{22}$ the global community, ${ }^{23}$ and the Justice Department's Office of Professional Responsibility. ${ }^{24}$

"undermined the ethics of the legal profession and violated the U.S. Constitution and the laws of the U.S., which they were sworn to uphold.").

17. In The Name of Democracy: American War Crimes In IraQ and Beyond 68, 77 (Jeremy Brecher, Jill Cutler, Brendan Smith, eds., 2005) (mentioning that an ACLU FOIA lawsuit uncovered classified legal memoranda indicating that the government implemented a common plan to execute abhorrent interrogation practices, covered up and lied about that scheme, isolated the plan from the law and courts, and rationalized how it was legal) [hereinafter In The Name of Democracy]; See Robert Bejesky, National Security Information Flow: From Source to Reporter's Privilege, 24 St. ThOMAS L. Rev. 399, 420-26 (2012) (discussing leaked documentation that revealed controversies); See e.g. Michael P. Scharf, International Law in Crisis: A Qualitative Empirical Contribution to the Compliance Debate, 31 CARdozo L. REv. 45, 85 (2009) (noting that the Bush Administration supposedly changed its opinion to treat al-Qaeda and Taliban members with some Geneva Convention protections, but this was declassified in January 2005); Michael P. Scharf, Accountability for the Torture Memo: International Law and the Torture Memos, 42 CASE W. RES. J. INT'L L. 321, 342 (2009).

18. In THE NAME OF DEMOCRACY, supra note 17, at 104, 107-09, 112-14, 193.

19. See generally Robert Bejesky, The Abu Ghraib Convictions: A Miscarriage of Justice, 32 Buff. PuB. INT. L.J. (forthcoming Apr. 2013)[hereinafter "Bejesky, Abu Ghraib Convictions"]; Bejesky, Pruning, supra note 4, at 823-28, 852.

20. Sen. Patrick Leahy, Op-Ed, There is No Justification for Torture, Boston GLOBE, June 28, 2004, at A11 ("It is . . clear that U.S. officials knew the law was being violated [during interrogations] and for months, possibly years, did virtually nothing about it."); Irene Zubaida Khan, The Rule of Law and the Politics of Fear: Human Rights in the Twenty-First Century, 14 Buff. Hum. RTS. L. ReV. 1, 5 (2008) (stating that the Bush Administration "condoned torture.").

21. 153 Cong. REC. S27303 (Oct. 16, 2007) (reporting that Jack Goldsmith revoked legal memos, including those pertaining to warrantless surveillance and the Bybee torture memo); See infra notes 239, 244, 291 and accompanying text for additional ostensible retractions.

22. U.S. Senate Democrats, Senate Republican Have Been Outspoken Against Torture-Will Their Votes Match Their Rhetoric?, Feb. 13, 2008, available at http://democrats.senate.gov/2008/02/13/senate-republicans-have-been-outspoken-against- 
Principal advisors issued opinions for the White House and secretary of defense that inverted the law in a broad range of areas, ${ }^{25}$ ignored legal precedent, misrepresented laws to achieve a preordained result, ${ }^{26}$ craftily carved loopholes on what was meant by torture, opined

torture-will-their-votes-match-their-rhetoric/\#.UxoZrT9dWa8 (last visited Mar. 21, 2014); Charles Babington \& Shailagh Murray, Senate Supports Interrogation Limits, WASH. POST, Oct. 6, 2005, available at http://www.washingtonpost.com/wpdyn/content/article/2005/10/05/AR2005100502062.html (last visited Mar. 21, 2014) ("Forty-six Republicans joined 43 Democrats and one independent in voting to define and limit interrogation techniques that U.S. troops may use against terrorism suspects, the latest sign that alarm over treatment of prisoners in the Middle East and at Guantanamo Bay, Cuba, is widespread in both parties.").

23. Michael J. Kelly, Responses to the Ten Questions, 35 WM.Mitchell L. REV. 5059, 5060 (2009) ("Because of Gitmo, torture at Abu Ghraib prison, the illegal invasion of Iraq, and other errors in judgment committed by the Bush administration, America is no longer regarded as a leader in human rights and an adherent to the rule of law."); UN Demands Prosecution of Bush-Era CIA Crimes, REUTERS, Mar. 4, 2013, available at http://rt.com/usa/un-crime-cia-bush-804/ (last visited Mar. 21, 2014) (reporting that "[a] United Nations investigator has demanded that the U.S. publish classified documents regarding the CIA's human rights violations under former President George W. Bush, with hopes that the documents will lead to the prosecution of public officials."); John H. Cushman Jr., U.N. Condemns Harsh Methods in Campaign Against Terror, N.Y. TIMES, Oct. 28, 2004, available at http://www.nytimes.com/2004/10/28/politics/28nations.html? r $=0$ (last visited Mar. 21, 2014) ("The United Nations official charged with monitoring compliance with international prohibitions against torture has sharply criticized several practices adopted by the Bush administration in its campaign against terrorism").

24. DEP'T OF Justice, OfFICE OF PROFESSIONAL RESPONSIBILITY, RePORT: InVESTIGATION into the OfFice of Legal Counsel's Memoranda Concerning Issues

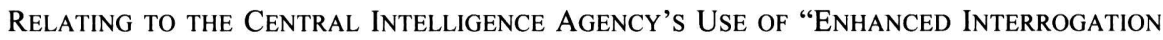
TECHNIQUES" ON SUSPECTED TERRORISTS 132, 260-61 (2009), available at http://judiciary.house.gov/hearings/pdf/OPRFinalReport090729.pdf (last visited Oct. 31, 2013); Philippe Sands, Poodles and Bulldogs: The United States, Britain, and the International Rule of Law, 84 IND. L.J. 1357, 1365 (2009) (criticizing the poor quality of the memos).

25. Several authors discussed the inversion of the rule of law. JORDAN J. PAUST, BEyOND THE LAW: THE BUSH ADMinistration's UnLAWFul RESPONSES IN THE "WAR" ON TERROR 86-100 (2007) (stating that top Bush Administration officials knew they were engaging in habitual lawbreaking, but they used lawyers to exonerate actions); see generally Stephen Grey, Ghost Plane: The True Story of the CiA Torture Program (2006); see also Seymour M. Hersh, Chain of Command: The Road From 9/11 to Abu Ghraib (2004); see generally MARK DANNER, TORTURE AND TRUTH: AMERICA, ABU GHRAIB, AND the War on Terror (2004); David Cole, Enemy Aliens: Double Standards and CONSTITUTIONAL FREEDOMS IN THE WAR ON TERRORISM (2003).

26. Scharf, supra note 16, at 389; Jordan J. Paust, Above the Law: Unlawful Executive Authorizations Regarding Detainee Treatment, Secret Renditions, Domestic Spying, and Claims to Unchecked Executive Power, 2007 UTAH L. REv. 345, 393 (2007) (stating that "Yoo and several others in the administration endorsed the theory ... of necessity to violate international law."). Over one hundred lawyers, five former members of Congress and twelve former judges, contended that the legal advisors transgressed professional 
that extraordinary defensive measures were imperative for gathering information from detainees, and contended that the series of four Geneva Conventions that define war crimes and prohibit torture ${ }^{27}$ were inapplicable or unavailing. ${ }^{28}$ Other scholars went further and called the opinions "embarrassing," "utterly unjustifiable" legal analyses, ${ }^{29}$ teeming with blatant errors, "not an attempt in good faith to assess the law,"30 "flout[ing] constitutional principle by establishing law-free zones and constitutional black holes," and offering "duplicitous parsing of legal obligations." 31

With the Bush Administration's request for legal memos, predetermined preference, receipt of opinions from select lawyers, and classification of advice, perhaps the result of torture can be expected. The ultimate repercussion of the memoranda was a dissipation of responsibility that diminished the likelihood that policymakers would confront punishment for torture even though inconsequential intervening events do not sunder the chain of causation between an act and harm to a victim in tort or criminal law. In short, given the consistent bias on pivotal issues when there were alternative interpretations of the law, it is not clear that the attorney-advisors were

obligations because the "memoranda . . . ignore and misinterpret the U.S. Constitution and laws, international treaties and rules of international law." Lawyers' Statement on Bush Administration's Torture Memos addressed to President George W. Bush, Vice President Richard B. Cheney, Secretary of Defense Donald Rumsfeld, Attorney General John Ashcroft, and Members of Congress (Aug. 2004), available at http://uclaprofs.com/petitions/040800torturememos.html (last visited Oct. 31, 2013).

27. Hague Convention for the Adaptation to Maritime Warfare of the Principles of the Geneva Convention, Oct. 18, 1907, 36 Stat. 2371; Geneva Convention Relative to the Treatment of Prisoners of War, Aug. 12, 1949, 6 U.S.T. 3316 [hereinafter "Geneva I"]; Geneva Convention Relative to the Protection of Civilian Persons in Time of War, Aug. 12, 1949, 6 U.S.T. 3516; Protocol Additional to the Geneva Conventions of August 12, 1949, and Relating to the Protection of Victims of International Armed Conflicts, June 8, 1977, 1125 U.N.T.S. 3 [hereinafter "Geneva Protocol Additional"].

28. See generally infra Part III.

29. Keller, supra note 6, at 551; Power, supra note 15, at 100 ("As I absorbed the opinions, I concluded that some were deeply flawed: sloppily reasoned, overbroad, and incautious in asserting extraordinary constitutional authorities on behalf of the President.").

30. O'Connell, Responses, supra note 5, at 5134.

31. Seth F. Kreimer, Rays of Sunlight in a Shadow "War": FOIA, The Abuses of AntiTerrorism, and the Strategy of Transparency, 11 LEWIS \& CLARK L. REV. 1141, 1142 (2007); David J. Barron \& Martin S. Lederman, The Commander in Chief at the Lowest Ebb - A Constitutional History, 121 HARV. L. REv. 941, 1096-98 (2008) (stating that Bush Administration assertions contended there was a right to defy Congressional will, laws, and treaties via expansive interpretation of the Commander in Chief clause); Ralph Wilde, Legal "Black Hole"? Extraterritorial State Action and International Treaty Law on Civil and Political Rights, 26 Mich. J. INT'L L. 739, 772-76 (2005) (remarking that commentators called these areas, such as Guantanamo Bay, a place where law does not apply). 
relevant when policymakers ostensibly had the intention to do whatever they wanted. The article assesses the far from fluky exonerating legal positions by dividing the advice into core constitutional arguments (Part II), factual extrapolations for Afghanistan (Part III), and the use of national security secrecy to circumvent more serious condemnation for several years (Part IV).

\section{DENYING RESTRICTIONS ON EXECUTIVE AUTHORITY}

Legal advisors opined that there are minimal constitutional restrictions on executive war powers authority, by espousing a capacious and unreviewable political question doctrine, abjuring applicability of substantive international law, assuming carte blanche for the Commander in Chief authority, and premising that exigency obviated the need for reasonable adherence to human rights law. If these foundational constitutional assertions had been convincing, advisors would have had no rationale for generating fact-specific opinions, which will be addressed in Parts III and IV. However, there were prima facie weaknesses in the constitutional advice.

First, the Bush Administration assumed that courts should not be involved in restricting government actions during the "war on terror," which invariably would abnegate detainees from attaining remedial relief for torture or receiving a review for the justification for imprisonment via habeas corpus challenges. ${ }^{32}$ Pursuant to Marbury $v$. Madison, the judiciary is the ultimate arbiter of constitutional interpretation, but will refrain from "questions, in their nature political." $" 33$ Courts are not prohibited from hearing cases with relations to foreign affairs. ${ }^{34}$ Additionally, a judiciary that too broadly sidesteps

32. Bejesky, Pruning, supra note 4, at 841-52; Robert Bejesky, War Powers Pursuant to False Perceptions and Asymmetric Information in the "Zone of Twilight," 44 ST. MARY's L.J. 1, 86-87 (2012) [hereinafter "Bejesky, War Powers"] (Yoo contending that the judiciary does not have a role in war powers cases despite much contrary evidence). Other denials were aimed at foreign petitioners. Vietnam Ass'n for Victims of Agent Orange/Dioxin v. Dow Chem., 373 F. Supp. 2d 7, 15-16, 43-44, 48, 81-82 (E.D.N.Y. 2005) (court dismissing Agent Orange case brought by Vietnamese plaintiffs against U.S. corporations because it would open the federal courthouse to "all of the Nation's past and future enemies," and the Bush Administration argued that herbicides were not banned, hearing the case would judge Executive war operations, and the Executive position prevailed over potential customary international law restrictions).

33. Marbury v. Madison, 1 Cranch 137, 170, 177 (1803); Edwin B. Firmage, The War Powers and the Political Question Doctrine, 49 CoLo. L. REv. 65, 68 (1977) (noting that because there is no political question doctrine in the Constitution, it is a common law development).

34. Lucien J. Dhooge, The Political Question Doctrine and Corporate Complicity in 
questions with tangential political overtones may forsake constitutional responsibilities ${ }^{35}$ and not serve justice, prevent executive wrongdoing, uphold the integrity of the American judicial system, fulfill reciprocal obligations to other states, or support the democratically-derived public choice of American citizens who heighten human rights. Indeed, the Supreme Court disagreed with legal advisors on habeas corpus challenges at Guantánamo Bay in a succession of cases-Hamdiv. Rumsfeld, Rasul v. Bush, Hamdan v. Rumsfeld, and Boumediene v. Bush. $^{36}$

Second, legal advisors attenuated the binding nature of U.S. obligations owed to other states under treaties and customary international law. ${ }^{37}$ Obscuring what were personal inclinations of appointed agents as institutional dissension, John Yoo stated: "The State Department and OLC often disagreed about international law. State believed that international law had a binding effect on the President, indeed on the United States, both internationally and domestically." ${ }^{38}$ Regarding the interpretation of treaties, Attorney General John Ashcroft, the Bush Administration's first attorney general, wrote that the President's "determination against treaty applicability would provide the highest assurance" that courts would not entertain charges against American agents for violating "Geneva Convention rules relating to field conduct, detention conduct or interrogation of detainees." 39

Extraordinary Rendition, 21 TEMP. INT'L \& COMP. L.J. 311, 332 (2007). But see Raines v. Byrd, 521 U.S. 811, 829-30 (1997) (holding that Congress persons can lack standing without a cognizable injury from the President's acts).

35. Fritz W. Scharpf, Judicial Review and the Political Question: A Functional Analysis, 75 YALE L.J. 517, 535-37 (1966).

36. Bejesky, War Powers, supra note 32, at 88.

37. Tel-Oren v. Lybian Arab Republic, 726 F.2d 774, 792 (D.C. Cir. 1984) (citing J. BRIERLY, THE LAW OF NATIONS $287\left(6^{\text {th }}\right.$ ed. 1963)) (stating that the law of nations has been defined as "the body of rules and principles of action which are binding upon civilized states and in their relations with one another").

38. JOHN YoO, WAR BY OTHER MEANS: AN InSIDER'S ACCOUNT OF THE WAR ON TERror 33 (Atl. Monthly Press) (2006); David Scheffer, Tenth Annual Grotius Lecture Series: For Love of Country and International Criminal Law, Further Reflections, 24 АM. U. INT'L L. REV. 665, 667-68 (2009) (stating that none of the principal legal advisors had a distinguished background in international law); Allen Buchanan, Democracy and the Commitment to International Law, 34 GA. J. INT'L COMP. L. 305, 307-08 (2006) (critiquing Posner and Goldsmith and their realist book) ("[N]ormative claims, if valid, would lend support to the view that it is wholly permissible for the U.S. government to take a purely instrumental stance toward international law, and that its citizens do not have a moral obligation to try to prevent their government from doing so.")

39. Document - USA: Torture, War Crimes, Accountability: Visit to Switzerland of Former US President George W. Bush and Swiss Obligations Under International Law: 
Ashcroft's point does not clearly jibe with Supreme Court precedent that affirms the President's war powers are circumscribed by Congress, jurisprudence that affirms the judiciary is the ultimate arbiter of the Constitution, ${ }^{40}$ Article 26 of the Vienna Convention which makes treaties binding on states and required to "be performed by them in good faith," 41 or the U.S. Supremacy Clause which states that "all Treaties made ... under the Authority of the United States, shall be the supreme Law of the Land." 42 An executive act, legislation, or court judgment can prevail over an inconsistent international law provision due to the last-in-time rule, ${ }^{43}$ but transgressing treaty obligations may still be an international law violation vis-à-vis other countries. ${ }^{44}$ There is also no evidence that Congress sanctioned the Bush Administration for violating the Geneva Conventions or authorizing interrogation techniques amounting to torture pursuant to the Joint Resolution for the Use of Force, the Patriot Act, ${ }^{45}$ or other executive war powers authority. ${ }^{46}$

A constitutional basis for discretionarily abrogating international law obligations is sorely lacking when government action eventuates into probable violations of jus cogens norms, universal jurisdiction crimes, and federal statutes prohibiting torture. ${ }^{47}$ From this

Amnesty International's Memorandum to the Swiss Authorities, AMNESTY INT'L, available at http://amnesty.org/en/library/asset/AMR51/009/2011/en/e82562ec-75c9-4092-9a3ad2d51484e67d/amr510092011 en.html (citing position of Ashcroft on Feb. 1, 2002) (last visited Nov. 3, 2013).

40. Bejesky, War Powers, supra note 32, at 10, 64, 86-87.

41. Vienna Convention on the Law of Treaties, art. 26, May 23, 1969, 1155 U.N.T.S. 331.

42. U.S. CONST. art. VI, $\S 2$.

43. The Paquete Habana, 175 U.S. 677, 700 (1900).

44. Restatement (Third) OF THE Foreign Relations Law of the United States $\S$ 111 (4) (1987); Nicaragua v. Reagan, 859 F.2d 929, 938 (D.C. Cir. 1988).

45. Derek Jinks \& David Sloss, Is the President Bound by the Geneva Conventions?, 90 CORNELl L. REV. 97, 134 (2004).

46. Robert Bejesky, Dubitable Security Threats and Low Intensity Interventions As the Achilles' Heel of War Powers, 32 Miss. C. L. Rev. 9, 19 (2013) (noting that Congress defines the scope of the president's war powers).

47. Murray v. Schooner Charming Betsy, 6 U.S. (2 Cranch) 64, 118 (1804) ("[A]n act of Congress ought never to be construed to violate the law of nations if any other possible construction remains."); O'Connell, Responses, supra note 5, at 5128 (noting that "[n]o government official has 'authority' to violate international law - no government official should wish to do so."); Jose E. Alvarez, Torturing the Law, 37 CASE W. RES. J. INT'L L. 175,186 (2006) (noting that the advisor's contention that the President's decision "concerning the detention of al-Qaeda and Taliban prisoners constitutes a "controlling Executive act' that is completely at odds with relevant Supreme Court precedents."); Id. at 179 (espousing that the legal advisors "twisted, in small and large ways, international 
vista and the fact that the U.S. law absolutely criminalizes torture, ${ }^{48}$ one should not need to rehash the obvious, but Congress did pass a ban on torture in December 2005 by a vote of 90 -to- 9 . However a few days later, Bush inserted a signing statement indicating that he would interpret the law "in a manner consistent with the constitutional authority of the President to supervise the unitary executive branch.,"49 Signing such statements are potentially unconstitutional and the use of "unitary" in this context is a solecism, ${ }^{50}$ but the practical impact was that the President was evidently still endeavoring to unilaterally define the fact-intensive conditions for detention and interrogation and thereby returning to the tantamount supposition that the Executive was not subject to constitutional constraints.

OLC advisors also denied the applicability of customary international law when it wrote "customary international law, as a matter of domestic law, does not bind the President, or restrict the actions of the U.S. military, because it does not constitute either federal law made in pursuance of the Constitution or a treaty recognized under

law.").

48. United Nations Convention against Torture and Other Cruel, Inhuman or Degrading Treatment or Punishment 5 CAT/C/28/Add.5, U.S. DEP'T OF ST. (Feb. 9, 2000), available at http://www.state.gov/documents/organization/100296.pdf (last visited Nov. 3, 2013) ("No official of the government, federal, state or local, civilian or military, is authorized to commit or to instruct anyone else to commit torture. Nor may any official condone or tolerate torture in any form. No exceptional circumstances may be invoked as a justification for torture.”); Harold Hongju Koh, WASH. MONTHLY (Jan./Feb./Mar. 2008), available at http://www.washingtonmonthly.com/features/2008/0801.koh.html (last visited Nov. 3, 2013) (Harold Hongju Koh, assistant secretary of state for democracy, human rights, and labor, testifying to a U.N. committee in 2000) ("In every instance, torture is a criminal offense. No official of the government ... is authorized to commit or instruct anyone else to commit torture.").

49. George W. Bush, President's Statement on Signing of H.R. 2863, Department of Defense, Emergency Supplemental Appropriations to Address Hurricanes in the Gulf of Mexico, and the Pandemic Influenza Act, 2006, WhITE HouSE (Dec. 30, 2005), available at http://georgewbush-whitehouse.archives.gov/news/releases/2005/12/20051230-8.html (last visited Nov. 3, 2013); Alfred M. MCCoy, A Question of TORTuRE 217 (2006); Eric Schmitt, Editorial, House Delays Vote on U. S. Treatment of Terrorism Suspects, N.Y. Times, Nov. 4, 2005, at A25 (reporting that the White House and the CIA lobbied to exempt the CIA from the restrictions).

50. Bejesky, War Powers, supra note 32, at 90-92; Jennifer Van Bergen, The Unitary Executive: Is the Doctrine Behind the Bush Presidency Consistent with a Democratic State? FINDLAW (Jan. 9, 2006), available at http://writ.news.findlaw.com/commentary/20060109_bergen.html (last visited Nov. 18, 2013) (noting that Bush issued 435 signing statements in his first term and used the term "unitary" in the statements 95 times, but signing statements could be unconstitutional under Chadha and Bowsher). 
the Supremacy Clause." ${ }^{51}$ Alternatively, the Restatement (Third) of U.S. Foreign Relations Law states "Customary law that has developed since the United States became a state is incorporated into United States law as of the time it matures into international law." 52 Scholars concur that torture is universally proscribed and that every state is bound to ensure that no one is subjected to torture as a jus cogens norm and customary international law. ${ }^{53}$

Third, legal advisors expressed that the President, as Commander in Chief, is not bound by law prohibiting torture when acting to provide national security and that "any effort by Congress to regulate the interrogation of battlefield combatants would violate the Constitution's sole vesting of the Commander-in-Chief authority in the President." ${ }^{, 54}$ If this position is accurate, international law that forbids

51. Jay S. Bybee, Assistant Attorney General, to Alberto Gonzalez, Gen. Counsel to the President \& William J. Haynes, General Counsel of the Department of Defense, Memorandum Re: Application of Treaties and Laws to al-Qaeda and Taliban Detainees 2 (Jan. 22, 2002), available at www.justice.gov/olc/docs/memo-laws-taliban-detainees.pdf (last visited Nov. 18, 2013). Courts decide cases based on "the Constitution, laws, and treaties of the United States [but do] not ... conform the law of the land to norms of customary international law." United States v. Yunis, 924 F.2d 1086, 1091 (D.C. Cir. 1991). Yoo wrote that no one previously thought to argue that the President has disregarded customary international law. However, there is actually a substantial literature delving into the issue. John O. McGinnis \& Ilya Somin, Should International Law Be Part of Our Law?, 59 Stan. L. Rev. 1175, 1226-30 (2007); Curtis A. Bradley \& Jack L. Goldsmith, Customary International Law as Federal Common Law: A Critique of the Modern Position, 110 HARV. L. Rev. 815, 844-46 (1997); Jordan J. Paust, The President Is Bound by International Law, 81 AM. J. INT'L L. 377 (1987); Louis Henkin, The President and International Law, 80 AM. J. INT'L L. 930 (1986); Michael J. Glennon, Raising The Paquete Habana: Is Violation of Customary International Law by the Executive Unconstitutional?, 80 Nw. U. L. REv. 321 (1985).

52. Restatement, supra note 44, at chap. 2, Introductory Note; Louis B. Sohn, The Universal Declaration of Human Rights, 8 J. INT'L COMMISSION JURISTS 17, 26 (1967) (noting that the Universal Declaration on Human Rights, which has been called "a part of the common law of the world community," together with the Charter of the United Nations, has achieved the character of the world law superior to all other international instruments and to domestic laws.").

53. See Bejesky, Pruning, supra note 4, at 829-35; Paust, supra note 26, at 418 (stating that "[t]he claim that the President has authority to violate international laws of war, human rights law, and domestic legislation is patently unconstitutional and unacceptable."); Alvarez, supra note 47, at 186 (calling the torture memoranda "shoddy and incomplete" on the question of treaties and a "cavalier" and "reckless" treatment of custom).

54. Jay S. Bybee, Memorandum for Alberto R. Gonzales re: Standards of Conduct for Interrogation under 18 U.S.C. $\S \S 2340-2340$ A 34-35, 39 (Aug. 1, 2002), available at http://www.washingtonpost.com/wp-

srv/nation/documents/dojinterrogationmemo20020801.pdf (last visited Nov. 16, 2013) ("In light of the President's complete authority over the conduct of war ... the prohibition against torture ... must be construed as not applying to interrogation undertaken pursuant to 
torture may be facially or upon application unconstitutional any time the President issues authorizations to conduct alleged terrorism- or combatant-related interrogations that eventuate into detainee abuse. ${ }^{55}$ Moreover, the Justice Department could not prosecute interrogators for violating the law if interrogators perpetrated torture pursuant to directives issued under the Commander-in-Chief authority. ${ }^{56}$ This advice is peculiar when official government investigations revealed, and media reports frequently surfaced with interrogators and military personnel being accused of significant harm and Bush affirmed that he

his Commander in Chief authority."). Similarly, in a March 2003 memo, Pentagon General Counsel William Haynes concurred and claimed that "in order to respect the President's inherent constitutional authority to manage a military campaign," the prohibition against torture "must be construed as inapplicable to interrogations undertaken pursuant to his Commander-in-Chief authority." Ingrid Arnesen, Detainees Not Covered by Geneva Conventions, Report Concluded, CNN (June 9, 2004), available at http://www.cnn.com/2004/LAW/06/09/detention.report/ (last visited Nov. 16, 2013); see Mary Ellen O'Connell, The Power AND Purpose of InTERnational LaW (2009) (critiquing Posner and Goldsmith's realist-oriented book and stating that "[a] policy-maker reading the book might well conclude that compliance with international law, such as the 1949 Geneva Conventions or the Convention against torture, is optional.").

55. Bybee, supra note 54, at 31 ("Even if an interrogation method arguably were to violate Section $2340 \mathrm{~A}$, the statute would be unconstitutional if it impermissibly encroached on the President's constitutional power to conduct a military campaign."); Dana Priest \& R. Jeffrey Smith, Memo Offered Justification for Use of Torture, WASH. Post (June 8, 2004), available at http://www.washingtonpost.com/wp-dyn/articles/A23373-2004Jun7.html (last visited Nov. 16, 2013) (noting that the legal advisors asserted that "international laws against torture 'may be unconstitutional if applied to interrogations' conducted in President Bush's war on terrorism.").

56. SenAte ARmed Services Committee, supra note 13, at xviii, xxi-xxii (stating that CIA and military officials were concerned about the legality of the methods, but Yoo advised that subordinates could not be prosecuted); Bybee, supra note 54, at 35, 31-39 (contending that U.S. officials carrying out orders could not be held responsible because they "would be aiding the President in exercising his exclusive constitutional authorities."). Yoo contended that "Congress doesn't have the power to 'tie the President's hands in regard to torture as an interrogation technique'... It's the core of the Commander-in-Chief function. They can't prevent the President from ordering torture." Jane Mayer, Outsourcing Torture: The Secret History of America's 'Extraordinary Rendition' Program, NEW YoRKER, Feb. 14 \& 21, 2005, at 114; In THE NAME OF DEMOCRACY, supra note 17, at 89-90 (stating that Haynes's memo asserted that the President could authorize any physical and psychological techniques to obtain "intelligence" to protect Americans, and that a presidential directive pursuant to wartime powers could be used by interrogators who torture suspects to avoid liability); Evan J. Wallach, The Logical Nexus Between the Decision to Deny Application of the Third Geneva Convention to the Taliban and al Qaeda and the Mistreatment of Prisoners in Abu Ghraib, 36 CASE W. RES. J. INT'L L. 541, 623 (2005) (stating that the Yoo/Delahunty Memorandum apply an eccentric "theory of ratification" that contends that the President has implied constitutional powers to issue orders to make actions of his subordinates inherently legal). 
"never ordered torture" ${ }^{\$ 57}$ and mandated that interrogators "stay within U.S. law." 58

If the advice contending that war crime prohibitions did not restrict either the Commander-in-Chief authority or derivative acts committed by subordinates had been sound, the President would not need to refute anything, or direct subordinates to remain within U.S. law, because Presidential directives and subsequent subordinate acts were above criminal laws restricting torture. Additionally, it is puzzling that states contemplated, negotiated, and ratified treaties applicable to war and armed combat with provisions that explicitly prohibited interrogation and accepted conventions proscribing torture under all circumstances, but these obligations were now inapplicable to the U.S. President ${ }^{59}$ when acting as "Commander in Chief," which is activated by Congress and foremost germane to directing U.S. troops into armed combat.

Fourth, one of Bybee's memoranda to Gonzales and Haynes also maintained that the Commander in Chief authority prevails over international and domestic law because self-defense and necessity can permit suspending legal obligations (such as the Geneva Conventions), ${ }^{60}$ allow harsh interrogations, and absolve interrogators from criminal liability. ${ }^{61}$ If the reasonableness of necessity and selfdefense are systematized as philosophical lenses of the world, such as with realist views of Thomas Hobbes who emphasized self-preservation at one pole and liberalist views of Immanuel Kant who emphasized the importance of human dignity at the other pole, Bush nestled closely to

57. Mike Allen \& Susan Schmidt, Memo on Interrogation Tactics is Disavowed, WASH. POST (June 23, 2004), available at http://www.washingtonpost.com/wpdyn/articles/A60719-2004Jun22.html (last visited Nov. 16, 2013).

58. President Bush Holds Press Conference Following the G8 Summit, White HouSE (June 10, 2004), available at http://georgewbushwhitehouse.archives.gov/news/releases/2004/06/20040610-36.html (last visited Nov. 16, 2013).

59. See generally STEPHEN KRASNER, SOVEREIGNTY 6 (1999) (stating that "[s]tronger states can pick and choose among different rules selecting the one that best suits their instrumental objectives," which may only require rationalizations to justify the action predominantly for the domestic audience).

60. Bybee, supra note 51, at 10-15, 27-29; Paust, supra note 26, at 356 (quoting John Yoo: "It seems to me that if something is necessary for self-defense, it's permissible to deviate from the principles of Geneva [including the prohibition of torture].").

61. Bybee, supra note 54, at 31-40; W. Bradley Wendel, Legal Ethics and the Separation of Law and Morals, 91 CoRNELL L. REV. 67, 84 (2005) (stating that if such notions are relayed down the chain of command, loose talk regarding necessity and selfdefense might persuade interrogators to conceive that their operations were justified). 
Hobbesian notions of self-preservation ${ }^{62}$ and therein impaired the opposing Kantian position as those of critics who were "soft on terrorism" and who unreasonably desired to limit presidential authority. ${ }^{63}$ There are several weaknesses in this position.

First, as the opening chart imparted, the driving perception of peril cast by the government into societal discourse may not be a rational and sober portrayal. Second, even with a gap between perception and reality, the President's core preclusive constitutional authority to suspend certain laws and take preemptive action refers to responding to an exigent and substantiated jeopardy that imperils the nation. ${ }^{64}$ The Bush Administration issued annual and ongoing public emergency inside the U.S. for several years, ${ }^{65}$ which was ostensibly specious when the country continued to function as usual. The post9/11 world is not the American Civil War, ${ }^{66}$ which enveloped two

62. Samuel Vincent Jones, The Ethics of Letting Civilians Die in Afghanistan: The False Dichotomy Between Hobbesian and Kantian Rescue Paradigms, 59 DePaul L. Rev. 899, 905, 907-08, 911-12 (2010); Robert Bejesky, Politico-International Law, 57 LoY. L. REV. 29, 44-47 (2011) (discussing the division between risk-averse realist and cooperative liberalist positions). Rumsfeld justified severe interrogation techniques by calling them "hardened criminals willing to kill themselves and others for their cause," and Cheney called captives "the worst of a very bad lot. They are very dangerous." PETER IRONS, WAR POWERS 248 (2005).

63. Philippe Sands, Torture Team 213 (2008).

64. President Thomas Jefferson stated that the "law of necessity, of selfpreservation,.. . [involves] saving our country when in danger.” DANIEL FARBER, LINCOLN's CONSTITUTION 193 (2003) (quoting Letter from Thomas Jefferson to John B. Colvin (Sept. 20, 1810), in Thomas JeFFerson: Writings 1231, 1231 (Merrill D. Peterson ed., 1984)). Secretary of State Daniel Webster explained that to use military force requires "a necessity of self-defense, instant, overwhelming, leaving no choices of means, and no moment for deliberation." R.Y. Jennings, The Caroline and McLeod Cases, 32 AM. J. INT'L L. 82, 89 (1938) (expressing that "acts of self-defense must occur only during the last feasible window of opportunity in the face of an attack that is almost certainly going to occur"). Rome Statute of the International Criminal Court, Int'l Law Comm'n, U.N. Doc. A/CONF.183/9 (July 17, 1998), available at http://untreaty.un.org/cod/icc/statute/romefra.htm (last visited Sept. 22, 2013) (“A personal shall not be criminally responsible if, at the time of that person's conduct... [t]he person acts reasonably to defend himself or herself or another person," or engaged in an act of military necessity required for survival that is proportionate to the danger).

65. Bejesky, Utilitarian Rational Choice, supra note 3, at 330-32, 340-41; Bejesky, Rational Choice Reflection, supra note 3, at 6-14, 21; A v. Secretary of State (No. 1) [2005] 2 A.C. [96]-[97] (British high court deciding that post-9/11 laws to respond to terrorism did not meet the definition of a public emergency under the ECHR because "[ $t]$ he real threat to the life of the nation, in the sense of a people living in accordance with its traditional laws and political values, comes not from terrorism but from laws such as these.").

66. Eric K. Yamamoto, Judgments Judged and Wrongs Remembered: Examining the Japanese American Civil Liberties Cases on Their Sixtieth Anniversary: White (House) Lies: Why the Public Must Compel the Courts to Hold the President Accountable for 
halves of a country seeking domination. Accepting similar conceptions of danger might permit any country to suggest national peril during criminal crackdowns and to engage in torture, suspend habeas corpus, and exonerate the crimes of government officials.

Third, the Bush Administration engaged in a bait-and-switch by stating that interrogation was necessary to thwart terrorism, but extended notions of self-defense and necessity inside and outside of war zones even though international agreements and customary international law expressly prohibit torture outside war zones, and the Geneva Conventions additionally prohibit interrogations inside war zones. ${ }^{67}$ Fourth, issuing orders for interrogations that approximate torture and violate jus cogens norms are prohibited under all circumstances. ${ }^{68}$

\section{APPLYING INTERNATIONAL LAW TO AFGHANISTAN}

\section{A. Gainsaying International Law by Factual Application}

As depicted in the last part, the claim that the President, under the Commander in Chief authority or other constitutional powers, can order subordinates to execute actions that constitute human rights violations is unpersuasive. ${ }^{69}$ Had the constitutional arguments been compelling, the legal advisors would not technically have needed to offer fact-specific exemptions for Afghanistan that sought the same outcome via legal contextualization. However, advisors did offer factintensive positions, including that Afghanistan was a failed state under Taliban control, combat in Afghanistan was "international in scope" but that the Geneva Conventions were not binding, the characteristics of

National Security Abuses, 68 L. \& CONTEMP. ProBS. 285, 288 (2005) (contending that "claims of urgent need" are false and are raised to "justify aggressive actions" and individual threat misrepresentations are only "the tip of proverbial iceberg" of a larger pattern of misrepresentations.)

67. Bejesky, Pruning, supra note 4, at 829-36.

68. Convention Against Torture and Other Cruel, Inhuman, or Degrading Treatment or Punishment, art. 2(2), opened for signature Dec. 10. 1984, 1465 U.N.T.S. 85 [hereinafter CAT] ("No exceptional circumstance whatsoever, whether a state of war or a threat of war, internal political instability or any other public emergency, may be invoked as a justification of torture."). In October 2004, Theo van Boven, UN Special Rappoteur on torture, responded to the Bush Administration's legal arguments involving "necessity" and "selfdefense" as justifications to attain information, and stated: "The condoning of torture is, per se, a violation of the prohibition of torture." Many Countries Still Appear Willing to Use Torture, Warns UN Human Rights Official, UN DAILY NEWS (Oct. 27, 2004), available at http://www.un.org/news/dh/pdf/english/27102004.pdf (last visited Nov. 8, 2013).

69. Bejesky, Pruning, supra note 4, at 823-35; Harold Hongju Koh, Friedmann Award Essay: A World Without Torture, 43 Colum. J. TRANSNAT'L L. 642, 648-49 (2005). 
combatants made them unprotected under the Geneva Conventions, approved interrogation techniques were not torture, and extraterritorial jurisdiction did not requisition elevated human right protections. If claims are sufficiently compelling, or are at least effectively immune from discredit, the likelihood of imposing liability for human rights abuses is reduced.

\section{B. Failed State}

In January 2002, legal advisors wrote that the Geneva Convention and the U.S. War Crimes Act did not apply to al-Qaeda or Taliban captives in Afghanistan because Afghanistan was a "failed state." ${ }^{70}$ The White House rapidly endorsed the opinion, ${ }^{71}$ but the underlying consultation is bothersome for several reasons.

First, under the 1933 Montevideo Convention, to qualify as a state there must be a defined territory, a permanent population, and a government in control that can enter into international relations. ${ }^{72}$ The question of political recognition is separate from state recognition ${ }^{73}$ and even if a state effectively collapses and the government does not discharge basic sovereign functions, the international community does not typically revoke recognition, ${ }^{74}$ but recognition can be employed by stronger states as a political instrument. ${ }^{75}$ Likewise, foreign powers

70. Bybee, supra note 51, at 2; Memorandum from Alberto R. Gonzales, Counsel to the President, to President George W. Bush (Jan. 25, 2002), available at http://www.torturingdemocracy.org/documents/20020125.pdf (last visited Nov. 8, 2013) (stating that international conventions did not apply to Afghanistan because the Taliban "did not exercise full control over the territory or over the people" of Afghanistan, "was not recognized by the international community," "could not fulfill international obligations," and was a militant group rather than a government, which made the Geneva Conventions "obsolete" and inapplicable in this new type of war); see also S.C. Res. 1378, U.N. Doc. S/RES/1378 (2001) (condemning the Taliban's governance over Afghanistan); Lawrence Azubuike, Status of the Taliban and al-Qaeda Soldiers: Another Viewpoint, 19 ConN. J. INT'L. L. 127, 134 (2003); David Akerson \& Natalie Knowlton, President Obama and the International Criminal Law of Successor Liability, 37 DENV. J. INT'L L. \& POL'Y 615, 633 (2009).

71. Paust, supra note 5, at 831 .

72. Montevideo Convention on the Rights and Duties of States, art. 1, Dec. 26, 1933, 49 Stat. 3097, 165 L.N.T.S. 19.

73. Id. art. 3 (stating that the "political existence of the state is independent of recognition by other states").

74. Theresa Reinold, State Weakness, Irregular Warfare, and the Right to Self-Defense Post-9/11, 105 A.J.I.L. 244, 249 (2011).

75. KRASNER, supra note 59, at 15 (noting that weaker states have typically argued that recognition should be automatic, whereas stronger states have selectively use recognition as a political instrument); Milena Sterio, A Grotian Movement: Changes in the Legal Theory of Statehood, 39 DENV. J. INT'L L. \& POL'y 209, 234-35 (2011) (noting that whether dominant 
cannot violate another state's sovereign rights even if a state lacks recognition ${ }^{76}$ because there are different types of sovereignty that do not covary; a state can have one form of sovereignty but not another, such as by retaining international law and Westphalian rights even when it does not exhibit convincing domestic sovereignty or cogent control. ${ }^{77}$ If the level of violence is an effective indicator, perhaps the Taliban was the legitimate government in control and did instill meaningful authority prior to the invasion, whereas Afghanistan slid more into a failed state status under U.S. occupation because the insurgency and fighting became more intense over the past eleven-year occupation. ${ }^{78}$

Second, Pakistan, Saudi Arabia, the UAE, ${ }^{79}$ some U.S. allies, and other countries officially recognized the Taliban as the legitimate government in power, ${ }^{80}$ which means that some states did regard the

and regional countries grant statehood is telling).

76. Sterio, supra note 75 , at $217-18$ (stating that as long as a territory has state sovereignty it has a sovereignty shield that a non-state does not necessarily possess); Milena Sterio, On the Right to External Self-Determination: "Selfistans," Secession, and the Great Powers' Rule, 19 MINN. J. INT'L L. 137, 148-49 (2010) (noting that there are some anomalies where a territory could be treated as a state when it does not possesses the four elements or a territory not being treated as a state when the four elements exist).

77. KRASNER, supra note 59, at 3-4, 12 ("A state with very limited effective domestic control could still have complete international legal sovereignty" and be recognized as a "juridical equal by other states.").

78. Stuart Hendin, Extraterritorial Application of Human Rights: The Differing Decisions of Canadian and UK Courts, 28 WINDSOR REV. L. \& SOC. IsSUES 57, 68 (2010) (pointing out that from 2005 to 2008, Foreign Policy published a list of "failed states" since 2005 and Afghanistan has been on the list); Seth G. Jones, The Rise of Afghanistan's Insurgency, 32 INT'L SEC. 7, 7-8 (2008) (noting that from 2002 to 2006, insurgent-initiated attacks increased by $400 \%$, and insurgent-initiated attacks increased another $27 \%$ in 2007); Deb Riechmann, Insurgent Attacks in Afghanistan Increase, ASSOCIATED PRESS, (July 27, 2012), available at http://www.newsday.com/news/world/insurgent-attacks-in-afghanistanincrease-1.3865838 (last visited Nov. 8, 2013) (insurgent attacks spiked in 2010 and exceeded that violence in 2012). Increased violence followed the invasion and occupation. As an example of similarly loose treatment in which no attributes of official sovereignty existed, in mid-December 2012, the U.S. recognized a purported coalition of rebel groups as the representative of the Syrian people. Jessica Golloher, Russia Slams US over its Syria Stance, VOA NEws, (Dec. 12, 2012), available at http://www.voanews.com/content/russiacriticizes-us-for-recognizing-syrian-opposition/1563252.html (last visited Nov. 8, 2013). The Assad family has ruled the country for decades. Erin McClam, Who are the Assads? Inside the family that has ruled Syria for decades, NBC NEws.COM (Aug. 30, 2013) available at http://worldnews.nbcnews.com/news/2013/08/29/20247267-who-are-theassads-inside-the-family-that-has-ruled-syria-for-decades?lite (last visited Nov. 8, 2013).

79. Srividhya Ragavan \& Michael S. Mireles, Jr., The Status of Detainees from the Iraq and Afghanistan Conflicts, 2005 UTAH L. REV. 619, 628 (2005).

80. Joshua S. Clover, Comment, "Remember, We're The Good Guys": The Classification and Trial of the Guantanamo Bay Detainees, 45 S. TEX. L. REv. 351, 359 (2004). 
Taliban as the de jure government. ${ }^{81}$ Afghanistan also remained a member of international institutions during the $1990 \mathrm{~s}^{82}$ Denying recognition to Afghanistan also seems affected and inconsistent with the facts because both the Clinton and Bush Administrations held diplomatic relations with the Taliban as they discussed a potential contract with multinational energy companies for constructing a transcountry pipeline. ${ }^{83}$ Consequently, even without being legallyrecognized or holding membership in organizations, the Taliban was at least the de facto government of Afghanistan. ${ }^{84}$

Third, Afghanistan was a party to the Geneva Conventions, ${ }^{85}$ which binds the territory and successive regimes after ratification. Legal advisers recognized that Afghanistan had been a party to the Geneva Conventions prior to the Taliban coming to power. ${ }^{86}$ The Geneva Conventions apply during all conflicts and to all combatants ${ }^{87}$ and humanitarian law is designed to protect human rights of everyone during combat and wars, ${ }^{88}$ which obviates the logic that inhabitants of a

81. Jordan J. Paust, Use of Armed Force against Terrorists in Afghanistan, Iraq, and Beyond, 35 CoRnell INT'L L.J. 533, 539 n.19, 543-44 (2002). Former State Department legal advisor William Taft IV wrote, "before, during, and after the emergence of the Taliban ... Afghanistan constituted a state." Mayer, supra note 56, at 112.

82. JefFrey L. Dunoff, SteVen R. Ratner \& David Wippman, International LaW: Norms, ACTORS, Process 116 (3d ed. 2010).

83. Robert Bejesky, Geopolitics, Oil Law Reform, and Commodity Market Expectations, 63 OKLA. L. REV. 193, 265-71 (2011) [hereinafter "Bejesky, Geopolitics"]; Azubuike, supra note 70, at 133 (stating that the U.S., through the CIA, reportedly helped bring the Taliban to power).

84. Annyssa Bellal, Gilles Giacca \& Stuart Casey-Maslen, International Law and Armed Non-State Actors in Afghanistan, 93 INT'L REV. OF THE RED Cross 25 (Mar. 2011), available at www.icrc.org/eng/assets/files/review/2011/irrc-881-maslen.pdf (last visited Nov. 6, 2013) (stating that "the Taliban before and in $2001 \ldots$ surely fulfilled the criterion of de facto authority over a population"); Johan Steyn, Guantanamo Bay: The Legal Black Hole, 53 INT'L \& COMP. L. Q. 1, 7 (2004) (“Before the armed conflict started, the Taliban government had been in effective control of Afghanistan."). Examples of de facto states include Abkhazia, Northern Cyprus, Northern Kosovo, Republika Srpska, Southern Ossetia and Taiwan. Sterio, supra note 75 , at 226.

85. Int'l Comm. of the Red Cross, Signatories to Protocol Additional to the Geneva Conventions of 12 August 1949, available at http://www.icrc.org/ihl.nsf/WebSign?ReadForm\&id=375\&ps=P (last visited Nov. 11, 2013) (Afghanistan signed in 1949 and became a party in 1956).

86. Bybee, supra note 51, at 10-11, 14-20.

87. Lawyers' Statement on Bush Administration's Torture Memos addressed to President George W. Bush, Vice President Richard B. Cheney, Secretary of Defense Donald Rumsfeld, Attorney General John Ashcroft, and Members of Congress, supra note 26 (over one hundred legal professionals signing).

88. Coard v. United States, Case 10.951, Inter-Am. C.H.R. 1283, OEA/Ser.L/V/II.106, doc.6 rev., at 1291 (1999), available at http://wwwl.umn.edu/humanrts/cases/us109-99.html 
territory cannot derive rights when present in a "failed state." Moreover, it is not clear that Geneva requires Afghanistan to be a party for the rules to be binding because Geneva law is non-derogative and is not premised on reciprocal compliance, but on obligations owed by and to all humankind. ${ }^{90}$ Common Article 3 of the Geneva Conventions mandates that all detainees "shall in all circumstances be treated humanely," which is an assurance that is not subject to the Executive discretion of a participant country. ${ }^{91}$

Fourth, as a practical argument, Bush's legal advisers maintained that a blanket non-suspension approach would be unwise because "international law would leave an injured party effectively remediless if its adversaries committed material breaches of the Geneva Conventions." ${ }^{92}$ Ergo, irrespective of whether obligations are driven by universality, American soldiers could not be guaranteed to receive protected treatment from a foe that is not bound to the Geneva Conventions when hospitable treatment is normally based on reciprocity. ${ }^{93}$ It is unfortunate that wartime humanitarian abuses can

(last visited Nov. 6, 2013) (Geneva rights should be viewed broadly because "individual rights inhere simply by virtue of a person's humanity"); Mayer, supra note 56, at 114 (A former State Department lawyer remarking: "There is no such thing as a non-covered person under the Geneva Conventions."); Robert A. Peal, Combatant Status Review Tribunals and the Unique Nature of the War on Terror, 58 VAND. L. REV. 1629, 1634 (2005) (noting distinctions between a war and armed conflict, such as the intensity of the violence, and capability of the parties to endure sustained fighting).

89. Memorandum from William H. Taft, IV, to Alberto Gonzales, Counsel to the President (Feb. 2, 2002), available at http://www.fas.org/sgp/othergov/taft.pdf (last visited Nov. 11, 2013) (responding to Yoo's draft and noting that carte blanche denial of POW status to the Taliban, assuming Afghanistan ceased to be a party to Geneva, that the president can suspend Geneva's applicability in Afghanistan, and that customary international law does not bind the U.S., are all wrong).

90. Paust, supra note 5, at 815,830 (calling the January 9, 2002 memo another "attempted avoidance of international and domestic criminal responsibility for interrogation tactics.”); Scharf, supra note 17, at 94-95 (former JCS General Richard Myers explaining: "We train our people to obey the Geneva Conventions, it's not even a matter of whether it is reciprocated-it's a matter of who we are.").

91. Paust, supra note 26 , at 407 ; Steyn, supra note 84 , at 5 (noting that "[w]hatever their status, such prisoners are entitled to humane treatment"); 3 COMMENTARY ON THE Geneva Convention Relative to the Treatment of Prisoners of War 35-37 (Jean S. Picteted., 1960) (stating that Common Article 3 is "applicable automatically, without any condition in regard to reciprocity"); Hamdan v. Rumsfeld, 126 S. Ct. 2749, 2796 (2005) (referencing that the ICRC also interprets Article 3 expansively and reasoned that "nobody in enemy hands can be outside the law"); Id at 2795-96 (holding that Article 3 of the Geneva Conventions applies to all expansive combat between countries and non-state actors).

92. Bybee, supra note 51, at 24-25.

93. Geneva I, supra note 27 , art. 43 (reciprocity requirement to provide names of 
occur, and that both sides of a conflict typically commit human rights abuses to varying degrees, ${ }^{94}$ but given that advisory opinions and Bush Administration statements were issued so early after invasion and captured detainees were quickly being removed from Afghanistan, one might even view that the Bush Administration provided the initial predominant signal to combatants in Afghanistan that the U.S. was not obligated to treat detainees with full protections. ${ }^{95}$ This is a costly signal for American troops because the Geneva Conventions are the most reliable framework that would protect Americans if they were captured in a foreign country, ${ }^{96}$ and compelling arguments can be made that the reputational effect for not providing humane treatment is grave.

\section{International in Scope}

Legal advisors concurred that the bulk of the Geneva Convention did not apply to protect al-Qaeda and the Taliban in Afghanistan because Common Article 2 applies to "armed conflict

individuals detained); id., art. 132 (obligation to exchange prisoners to the other side when hostilities end). Perhaps somewhat baffling with such consternation over reciprocity, is that the legal advisors initially contended (and the Bush Administration agreed) that the Geneva Conventions were inapplicable to al-Qaeda and the Taliban, which insinuates that the foe must also not be bound, but Gonzales opined that customary laws of war could still be utilized to bring war crimes charges against al-Qaeda and the Taliban for combat in Afghanistan. Bybee, supra note 51, at 2-3, 25 ("Taliban troops ... torture any American prisoners ... [t] he U.S. military thus could prosecute Taliban militiamen for war crimes for engaging in such conduct.").

94. Michael IgnatiefF, The LeSSER EVIL 115-19 (2004).

95. M. Cherif Bassiouni, The New Wars and the Crisis of Compliance with the Law of Armed Conflict by Non-State Actors, 98 J. CRIM. L. \& CRIMINOLOGY 711, 758 (2008) (contending that when the Bush Administration violated International Humanitarian Law, it "provided an added incentive for non-state actors to take the position that IHL does not apply to them.").

96. Memorandum from Colin Powell, Secretary of State, to Alberto Gonzalez, Counsel to the President 1 (Jan. 26, 2002), available at http://www.gwu.edu/ nsarchiv/NSAEBB/NSAEBB127/02.01.26.pdf (last visited Nov. 13, 2013) (stating the Geneva Conventions should apply to those captured in Afghanistan and failure to do so would "reverse over a century of U.S. policy and practice in supporting the Geneva conventions and undermine the protections of the law of war for our troops, both in this specific conflict and in general"); Joby Warrick, Administration says Particulars may Trump Geneva Protections, WASH. POST (Apr. 27, 2008), available at http://articles.washingtonpost.com/2008-04-27/politics/36898081_1_interrogationbenczkowski-letters (last visited Nov. 13, 2012). Senator Graham, who opposed the administration's detainee policies, remarked that the Geneva Convention "rules we set up speak more about us than it does the enemy." Kate Zernike, G.O.P. Senator Resisting Bush over Detainees, N.Y. TIMES (July 18, 2006), available at http://www.nytimes.com/2006/07/18/washington/18graham.html?pagewanted=all\&_r=0 (last visited Nov. 13, 2013). 
"between two or more of the High Contracting Parties"” and Article 3 did not apply. ${ }^{97}$ Common Article 2 refers to conflict with two or more opposing states engaged in international armed conflict; ${ }^{98}$ and Common Article 3 applies to non-international armed conflict, ${ }^{99}$ which by process of elimination, applies to any type of conflict not involving two rival states, such as combat between government forces and insurgents or non-governmental forces. Common Article 3 is consistent with ensuring that all persons involved in conflict have human rights and are protected. $^{100}$

97. Bybee, supra note 51, at 9 ("[A] non-governmental organization cannot be parties to any of the international agreements here governing the laws of war. . al-Qaeda is not a High Contracting Party. As a result, the U.S. military's treatment of al-Qaeda members is not governed by the bulk of the Geneva Conventions, specifically those provisions concerning POWs."); see also id. at 9-10 (al-Qaeda is a "non-governmental terrorist organization" and al-Qaeda and the Taliban were criminal organizations, which meant there were no available protections under the Third Geneva Convention.). Gonzales, Haynes, and Yoo concurred. Tim Golden, After Terror, a Secret Rewriting of Military Law, N.Y. TIMES (Oct. 24, 2004), available at http://www.nytimes.com/2004/10/24/international/worldspecial2/24gitmo.html?pagewanted $=$ all\&position $=($ last visited Nov. 13, 2013) (Gonzales called the opinion "definitive."). Haynes and Yoo contended that "neither the Third nor Fourth Geneva Conventions protected al-Qaeda and Taliban detainees captured in Afghanistan," and Bybee contended that "neither the federal War Crimes Act nor the Geneva Conventions would apply to the detention of al-Qaeda prisoners." Bybee, supra note 51, at 37; Jeremy Waldron, Torture and Positive Law: Jurisprudence for the White House, 105 ColuM. L. REV. 1681, 1691 (2005) (noting that Yoo contended that the Geneva Conventions "apply to some captives or detainees but not to others, and that they do not apply to al-Qaeda and Taliban detainees in the war on terror."). On April 4, 2003, Air Force General Counsel Mary Walker concurred that the Taliban was not afforded protection under the Geneva Convention because they are "unlawful combatants" and that it does not apply to al-Qaeda because al-Qaeda is not a contracting party. Paust, supra note 5, at 841-42.

98. Geneva Convention for the Amelioration of the Condition of the Wounded and Sick in the Armed Forces in the Field art. 2, Aug. 12, 1949, 6 U.S.T. 3114, 75 U.N.T.S. 31, [hereinafter "Geneva II"]. An "armed conflict," whether of an international or noninternational character is "a resort to armed force between States or protracted armed violence between governmental authorities and organized armed groups or between such groups within a State." Prosecutor v. Tadic, Case No. IT-94-1-I, Decision on Defence Motion for Interlocutory Appeal on Jurisdiction, I 70 (Int'l Crim. Trib. for the former Yugoslavia Oct. 2, 1995).

99. Article Three applies in "cases of armed conflict not of an international character occurring in the territory of one of the High Contracting Parties." Geneva I, supra note 27, art. 3; Geneva II, supra note 98, art. 3; Geneva Convention for the Amelioration of the Condition of the Wounded, Sick and Shipwrecked Members of Armed Forces at Sea art. 3, Aug. 12, 1949, 6 U.S.T. 3217, 75 U.N.T.S. 85 [hereinafter "Geneva III"].

100. See Shannon M. Roesler, The Ethics of Global Justice Lawyering, 13 YALE H.R. \& DEV. L.J. 185, 208 (2010) (noting that an egalitarian understanding of the law mandates that all human beings be regarded with equal worth); see O'Connell, Responses, supra note 5 , at 5132 (noting that "all persons caught up in armed conflict have the protections of the Geneva Conventions - all persons"); see also Jordan Paust, Post-9/11 Overreaction and 
Citing legal memoranda, Bush announced that he had "the authority under the Constitution to suspend Geneva as between the United States and Afghanistan," but would not presently do so; that he accepted legal advice contending that "Article 3 of Geneva does not apply to either al-Qaeda or Taliban detainees, because, among other reasons, the relevant conflicts are international in scope and common Article 3 applies only to 'armed conflict not of an international character;", and that he would still apply provisions of Geneva "to our present conflict with the Taliban." 101

There is substantial precedent to support the position that battling terrorism is an international armed conflict requiring Geneva protections, ${ }^{102}$ but it might have even been logical to announce that American operations in Afghanistan did not involve armed conflict of

Fallacies Regarding War and Defense, Guantanamo, the Status of Persons, Treatment, Judicial Review of Detention, and Due Process in Military Commissions, 79 Notre DAME L. REv. 1335, 1351 (2004) (stating that Article 3 of all four Geneva Conventions guarantee minimum protections, including the right to be free from torture, humiliation, and cruel and unusual treatment, and to be treated humanely, and Article 3 applies to all detainees, including POWs and unprivileged belligerents).

101. Memorandum from President George W. Bush, to Vice President Dick Cheney, et al. (Feb. 7, 2002), available at http://www.aclu.org/files/assets/CIA.pdf (last visited Nov. 13, 2013); Fact Sheet: Status of Detainees at Guantanamo, WHITE HouSE, available at http:/georgewbush-whitehouse.archives.gov/news/releases/2002/02/20020207-13.html (last visited Nov. 13, 2013) ("Although we never recognized the Taliban as the legitimate Afghan government, Afghanistan is a party to the [Geneva] Convention, and the President has determined that the Taliban are covered by the Convention.").

102. Comm'n of Inquiry on Lebanon, Rep. Pursuant to Human Rights Council Resolution S-2/1, If 55, U.N. Doc. A/HRC/3/2, (Nov. 23, 2006) (finding the fighting between Israel and Hezbollah an international armed conflict, substantially because Hezbollah was called a "militia belonging to a Party to the conflict."); HCJ 769/02 Public Comm. Against Torture in Israel v. Gov't of Israel, at 43 [2006], available at http://elyon1.court.gov.il/Files_ENG/02/690/007/A34/02007690.a34.pdf (holding that military operations against terrorism involved an "armed conflict of an international character," requiring application of the Geneva Conventions); contra Hamdan v. Rumsfeld, 548 U.S. 557, 628-31 (2006) (calling conflict with al-Qaeda a non-international armed conflict); see also Marko Milanovic, Lessons for Human Rights and Humanitarian Law in the War on Terror: Comparing Hamdan and the Israeli Targeted Killings Case, 89 INT'L REV. RED CROSS 373, 377-78 (2007), available at http://www.icrc.org/eng/assets/files/other/irrc_866_milanovic.pdf (last visited Nov. 13, 2013). Also, if there is a sufficiently substantial connection between a state and a nongovernmental group, then the fighting should be called an international conflict. Sylvain Vite, Typology of Armed Conflicts in International Humanitarian Law: Legal Concepts and Actual Situations, 91 INT'L REv. RED. CROSS 69, 71 (2009), available at http://www.icrc.org/eng/assets/files/other/irrc-873-vite.pdf (last visited Nov. 13, 2013); Prosecutor v. Tadic, Case No. IT-94-1-A Judgment on Appeal, ๆ 92-93, (Int'l Crim. Trib. for the former Yugoslavia July 15, 1999), http://www.icty.org/x/cases/tadic/acjug/en/tadaj990715e.pdf (holding that there is an international armed conflict when a non-state group is in conflict with another state when the non-state group "belongs to" another state). 
an international character, perhaps due to the "failed state" allegation, as long as one finds that operations involve conflict not of an international character, ${ }^{103}$ which implicitly still means that basal Geneva Convention rights apply. Ultimately, with Bush offering the indecisive comment of having authority to "suspend the Geneva Convention" 104 and that minimal standards of Article 3 did not apply, an impression is seemingly implanted that nothing is truly binding and that any protection from that origin of zilch appears gratuitous. Ironically enough, Bush did not eagerly apply Geneva provisions, ${ }^{105}$ but instead stated several years later that Article 3 applied. ${ }^{106}$

The other problem stems from the use of heuristics-the targeted foe evolved and there was selective use of the phrase "war on terrorism" to empower the president on the one hand and reduce international law restrictions on the other. Congress passed the Authorization for Use of Military Force (AUMF) in September 2001 to permit the U.S. military to capture Osama bin Laden and those associated with 9/11, which was then expanded to suspected al-Qaeda members in Afghanistan, to the Taliban, and to segments of the Afghani population that opposed the occupation after the U.S. installed a president and established military bases. ${ }^{107}$ The United Nations called the attack on Afghanistan a "war" between two states, and Bush said the attack on Afghanistan was part of a "war on terror" apparently harbored those connected to $9 / 11 .{ }^{108}$ Thus, for purposes of unleashing unbridled

103. Military and Paramilitary Activities in and Against Nicaragua (Nicar. v. U.S.), 1986 I.C.J. 14, 64-65, ๆ1 114-16 (June 27) (holding that the Contras' battle against the legitimate government of Nicaragua was a non-international armed conflict, but the U.S. involvement in training, equipping, and financing the Contras did not result in effective control over the Contras); David Glazier, Playing By the Rules, 51 WM. \& MARY L. Rev. 957, 994 (2009) (discussing the battle with al-Qaeda and expressing that "[i]f the choice is between the rules governing 'international' and 'noninternational' conflict, then the former is clearly the better alternative.").

104. WhITE HOUSE, supra note 101 (Bush remarking: "Although we never recognized the Taliban as the legitimate Afghan government, Afghanistan is a party to the [Geneva] Convention, and the President has determined that the Taliban are covered by the Convention.").

105. William H. Taft, The Geneva Conventions and the Rules of War in the Post-9/11 and Iraq World, 21 AM. U. INT'L L. REV. 149, $154-55$ (2005) (noting that Bush did not implement the provisions).

106. Exec. Order No. 13,440, 72 Fed. Reg. 40,707 (July 20, 2007) (“Common Article 3 shall apply to a program of detention and interrogation operated by the Central Intelligence Agency.")

107. Bejesky, Geopolitics, supra note 83, at 273.

108. Bush Gives Update on War Against Terrorism, CNN (Oct. 11, 2001), available at http://articles.cnn.com/2001-10-11/us/gen.bush.transcript_1_terror-islamic-nationswar?_s=PM:US ("[W]ar against all those who seek to export terror and a war against those 
moral and legal authority or power and deploying sophisticated weaponry and aircraft and the U.S. military under the Commander-inChief authority to combat a formidable army, it is a war, ${ }^{109}$ which suggests there is an international armed conflict and Article Two should have applied inside Afghanistan.

The inconsistency arises when al-Qaeda as the enemy is emphasized to call it a "global" war, but under international law, a state cannot be at war with belligerents, insurgents, or non-state actors, such as Osama bin Laden. Only Congress can declare war and it technically never authorized any broadly construed "war on terror," 110 but Bush interpreted the AUMF to assume expansive Commander-in-Chief authority for war against "every terrorist group of global reach." 111 However, because war is a conflict involving at least two opposing states, ${ }^{12}$ perhaps commentators are correct that "the war on terror" was

governments that support or shelter them."); Ragavan \& Mireles, supra note 79, at 629-30; Johannes van Aggelen, The Bush Administration's War on Terror: The Consequences of Unlawful Preemption and the Legal Duty to Protect the Human Rights of Victims, 42 CASE W. RES. J. INT'L L. 21, 30 (2009) ("Neither of the Security Council resolutions nor NATO's September 12, 2001 statement attempted to establish a link between terrorist acts and a particular state.") NATO members deployed troops. Kenneth Anderson, United Nations Collective Security and the United States Security Guarantee in an Age of Rising Multipolarity: The Security Council as the Talking Shop of the Nations, 10 CHI. J. INT'L L. 55, 68 (2009) ("[NATO] went along to support an ally in a general sense, [but] not because they believed this mission was actually core to the NATO mutual security pact.").

109. Stephen P. Marks, Branding the "War on Terrorism": Is There a "New Paradigm" of International Law? 14 MiCH. ST. J. INT'L L. 71, 88-89 (2005).

110. Robert Bejesky, Cognitive Foreign Policy: Linking al-Qaeda and Iraq, 56 How. L.J. 1, 8-11 (2012) [hereinafter "Bejesky, CFP"]; Paust, supra note 26, at 346; see contra Curtis A. Bradley \& Jack L. Goldsmith, Congressional Authorization and the War on Terrorism, 118 HARV. L. REV. 2047, 2056-57 (2005) (disagreeing with those contending that "powers being granted to the President are limited or truncated in some fashion because Congress has not declared war" and that "the powers granted to the President in the AUMF are limited or truncated in some fashion because conflict with terrorists is not a 'real war."').

111. Marks, supra note 109, at 75; Jeffrey F. Addicott, Efficacy of the Obama Policies to Combat Al-Qa'eda, the Taliban, and the Associated Forces - The First Year, 30 PACE L. REv. 340, 344-45 (2010) (stating that the "War on Terror" is "not accurate in what it purported to describe" and does not list an enemy); Thomas P. Crocker, Overcoming Necessity, 61 SMU L. REv. 221, 230 (2008) ("By invoking a so-called 'war on terrorism,' government officials seek the availability of exceptional powers to act.").

112. Jean-Jacques Rousseau, On the Social Contract: Discourse on the Origin OF INEQUALITY, Discourse on PoliticAl ECONOMY 21-22 (Donald A. Cress trans., Hackett Publ'g Co. Inc. 1983) (1762) ("War is not therefore a relationship between one man and another, but relationship between one state and another. In war private individuals are enemies only incidentally: not as men or even as citizens, but as soldiers."); YORAM Dinstein, War, AGgression AND SElf-Defense 5 (4th ed. 2005) ("In all definitions it is clearly affirmed that war is a contest between states."). 
only a metaphor ${ }^{113}$ that called for improved police work. ${ }^{114}$ Whatever the invasion of Afghanistan should have been called, and whether it was international or non-international conflict, international law does not permit denying Geneva Convention protections or grant a right to engage in interrogation tactics that may be torture. ${ }^{115}$ Nonetheless, the bifurcation of the enemy and select use of rhetoric may also have led to esoteric assumptions about U.S. military operations in foreign lands and another legal loophole that rejected occupation and human rights law, which ordinarily guarantee generally-applicable rights even when the Geneva Conventions are inapplicable.

\section{Extraterritorial Jurisdiction}

The International Covenant on Civil and Political Rights (ICCPR) affirms: "Each State Party to the present Covenant undertakes to respect and to ensure to all individuals within its territory and subject to its jurisdiction the rights recognized in the present Covenant."116 The Bush Administration reduced the ICCPR's jurisdictional applicability by omitting the "subject to its jurisdiction" portion of the provision and contended that U.S. human rights obligations were only available in the "territory of the United States."117 Alternatively, Germany, the U.K., Australia, and Belgium all executed documents with the UN that recognized that they accepted jurisdiction over actions of their forces deployed to Afghanistan and Iraq; ${ }^{118}$ U.S. military doctrine requires human rights treaties to be followed in foreign stability operations; ${ }^{119}$

113. Brooks, supra note 6, at 716-17; George Anastaplo, September 11th, A Citizen's Responses (Continued), 4 LOY. INT'L L. REV. 135, 157 (noting that 9/11 was "a vicious assault by a gang of international criminals"); Scott Wilson \& Al Kamen, "Global War on Terror" is Given New Name, WASH. POST (Mar. 25, 2009), available at http://articles.washingtonpost.com/2009-03-25/politics/36918330_1_congressionaltestimony-obama-administration-memo (last visited Nov. 13, 2013).

114. Anastaplo, supra note 113, at 154.

115. CAT, supra note 68.

116. International Covenant on Civil and Political Rights art. 2(1), Dec. 19, 1966, 999 U.N.T.S. 171 [hereinafter "ICCPR"].

117. U.N. Human Rights Comm., Consideration of Reports Submitted by States Parties Under Article 40 of the Covenant, Concluding Observations of the Human Rights Comm.: United States of America, ๆ 130, U.N. Doc. CCPR/C/USA/3 (Nov. 28, 2005).

118. Sarah H. Cleveland, Embedded International Law and the Constitution Abroad, 110 COLUM. L. ReV. 225, 256 n.124 (2010).

119. U.S. DeP't of ARMY, Field Manual 3.07: Stability Operations 1-7 (Oct. 6, 2008), available at http://usacac.army.mil/cac2/repository/FM307/FM3-07.pdf (last visited Nov. 13, 2013); U.S. DeP'T OF DEF., JoINT Publication 1, JoINT WARFARE OF THE ARMED FORCES OF THE UNITED STATES, at II-2 (Jan. 10, 1995), available at http://webapp1.dlib.indiana.edu/cgi- 
and the Bush Administration's position was inconsistent with existing precedent of the International Court of Justice (ICJ) ${ }^{120}$ the InterAmerican Committee on Human Rights, ${ }^{121}$ UN Human Rights Committee, ${ }^{122}$ and the UN General Assembly, ${ }^{123}$ which have affirmed that human rights treaties apply beyond a state's territory.

European Court of Human Rights (ECHR) precedent is not binding on the U.S., but interpretations provide insight and persuasive

bin/virtcdlib/index.cgi/4240529/FID6/pdfdocs/jel/new_pubs/jp1.pdf (last visited Nov. 13, 2013) ("[Military officials and troops] respect human rights. We observe the Geneva Conventions not only as a matter of legality but from conscience.").

120. Legal Consequences of the Construction of a Wall in the Occupied Palestinian Territory, Advisory Opinion, 2004 I.C.J. 136, ๆ 109 (July 9) (holding that the jurisdiction of states "may sometimes be exercised outside the national territory," particularly when there is a "constant practice" of exercising control over that territory); Legal Consequences for States of the Continued Presence of South Africa in Namibia (South West Africa) notwithstanding Security Council Resolution 276, Advisory Opinion, 1971 I.C.J. 16, If 39 (June 21) ("[T]he fact that South Africa no longer has any title to administer the Territory does not release it from its obligations and responsibilities under international law"). The Wall advisory opinion states that the Convention on Social, Economic and Cultural Rights, the ICCPR, and the International Covenant on Social, Economic and Cultural Rights, all apply extra-territorially when a state exercises effective control over a foreign territory. Tom Dannenbaum, Translating the Standard of Effective Control into a System of Effective Accountability: How Liability Should be Apportioned for Violations of Human Rights by Member State Troop Contingents Serving as United Nations Peacekeepers, 51 HARV. INT'L L.J. 113, 130 (2010); Cleveland, supra note 118, at 259-60 (noting that the ICJ has held that either territorial control or "effective control" implicates international legal obligations).

121. Decision on Request for Precautionary Measures (Detainees at Guantanamo Bay, Cuba), Inter-Am. Comm'n H.R. (Mar. 12, 2002), reprinted in 41 I.L.M. 532, 533-34 (2002). (determining that detainees held at Guantanamo Bay were held under the "authority and control" of the U.S. military, making human rights treaties applicable); Alejandre v. Cuba, Case 11.589, Inter-Am. Com'n H.R., Report No. 86/99, OEA/Ser.L./V/II.106, doc. 3 rev. P 25 (1999).

122. U.N. Human Rights Comm., General Comment No. 31 [80], The Nature of the General Legal Obligation Imposed on States Parties to the Covenant, 80th Sess., May 26, 2004, U.N. Doc. CCPR/C/21/Rev.1/Add.13, at ๆๆ 2, 9-10 (March 29, 2004), available at http://www.unhcr.org/refworld/pdfid/478b26ae2.pdf (last visited Nov. 13, 2013) (ICCPR jurisdiction applies, based on reciprocal obligations, to states for "all persons who may be within their territory" and "to all persons subject to their jurisdiction" when the party has "effective control" over the territory); Saldias de Lopez v. Uruguay, Communication No. $52 / 1979$, at 88 , I 12.3, U.N. Doc. CCPR/C/OP/1 (1984) (holding that "it would be unconscionable to so interpret the responsibility under article 2 of the Covenant [ICCPR] as to permit a State party to perpetrate violations of the Covenant on the territory of another State, which violations it could not perpetrate on its own territory."); ICCPR, supra note 116 , art. 2(1) (stating that the agreement applies "to all individuals within its territory and subject to its jurisdiction").

123. Patrick Walsh, Fighting for Human Rights: The Applicability of Human Rights Treaties to United States' Military Operations, 28 PENN ST. INT'L L. REV. 45, 53-54 (2009); Heidi Krieger, A Conflict of Norms: The Relationship Between Humanitarian Law and Human Rights In the ICRC Customary Law Study, 11 J. OF CONFLICT \& SEC. L. 268 (2006). 
precedent to the jurisdictional applicability of human rights via "effective control." 124 Article 1 of the ECHR employs language guaranteeing that all persons shall have secure rights and freedoms "within [the] jurisdiction" of the parties. ${ }^{125}$ Consequently, the ECHR grants protection "to everyone within their jurisdiction," 126 which includes extending obligations on a member state when there is effective control outside national territory, including for what follows after lawful or unlawful military action. ${ }^{12}$

The ECHR addressed case specific facts involving the occupation of Iraq and extended ECHR obligations to member states due to effective control. ${ }^{128}$ With respect to the U.S., the Security Council authorized occupation, ${ }^{129}$ which inherently affirms effective control, including after a new Iraqi government was installed, because "territory is considered occupied when it is actually placed under the authority of the hostile army." "30 Scholars may disagree over the point at which "war" in Afghanistan turned to occupation.

124. Cleveland, supra note 118, at 261-66 (emphasizing that effective jurisdiction is consistent with other ECJ cases and that "effective control" is not limited to a state's sovereign territory).

125. Convention for the Protection Of Human Rights and Fundamental Freedoms, art. 1, Sept. 3 1953, 213 U.N.T.S. 221.

126. Id.

127. Bankovic v. Belgium, 2001-XII Eur. Ct. H.R. 335, 354-55 (holding that extraterritorial jurisdiction is particularly appropriate when acts of state "produced effects or were performed outside their own territory, where as a consequence of military action (lawful or unlawful) the state exercised effective control of an area outside its national territory, whether it was exercised directly, through the respondent state's armed forces, or through a subordinate local administration"); Loizidou v. Turkey, 310 Eur. Ct. H.R. 7, 2122, 24-25 (ser. A) (1995) (holding that that Turkey was in effective control over Cyprus because it possessed authority to implement and enforce policies with a military presence of 30,000 troops, and was liable for upholding human rights in Northern Cyprus).

128. Al-Skeini v. Sec'y of State for Def., [2007] UKHL 26, [2007] 1 A.C. (H.L.) [153] (case involving British soldiers apparently killing six Iraqi citizens in Iraq (one was reportedly in a British detention facility)); Dan E. Stigall, Counterinsurgency and Trends in the Law of International Armed Conflict, 30 PA. J. INT'L L. 1367, 1373-75 (2009) (describing how the Al-Skeini case history depicts some unwillingness within British institutions to accept jurisdiction over British acts in Iraq); Abbasi v. Sec'y of State for Foreign and Commonwealth Affairs [2002] EWCA (Civ) 1598, [64], [66], available at http://www.bailii.org/ew/cases/EWCA/Civ/2002/1598.html (last visited Nov. 21, 2013) (holding that U.S. detentions of noncitizens, who are "subject to indefinite detention in territory over which the U.S. has exclusive control with no opportunity to challenge the legitimacy of his detention before any court of tribunal," were arbitrary and "in apparent contravention of fundamental principles").

129. S.C. RES. 1483, U.N. Doc. S/RES/1483 (May 22, 2003)(recognizing obligations of the legal status of occupation).

130. Convention (IV) Respecting the Laws and Customs of War on Land, art. 42, Oct. 
Despite all the precedent relating to jurisdictional applicability of the ICCPR, it may still be reasonable to interpret from the negotiating history and objections that the ICCPR was not always intended to apply beyond a state's sovereign territory for military operations, but this is because international humanitarian law is required to be followed during combat. ${ }^{131}$ The problem is rather obvious because the last part addressed how the Bush Administration used fuzzy reasoning with Article 2 and Article 3 of the Geneva Convention to deny full applicability of international humanitarian law. ${ }^{132}$ Another method of denying international law restrictions is to focus on the characteristics of the enemy, which could also deny POW status and advance a policy of removing detainees from Afghanistan and transporting them across the Atlantic Ocean to Guantánamo; a location with an "ambiguous legal status" $" 133$ and that may have been partially relevant to the removal of detainees from Iraq ${ }^{134}$ and to abductions and Extraordinary Rendition of suspected terrorists in other parts of the world. ${ }^{135}$

18, 1907, 36 Stat. 2277, 2306, 1 Bevans 631.

131. Walsh, supra note 123, at 51-52. U.S. DeP'T OF STATE, List of Issues to BE Considered During the Examination of the Second Periodic Report of THE United StATES OF AMERICA: Responses of THE United States of AMERICA, at 32 (Apr. 28, 2006), available at http://www.state.gov/documents/organization/68662.pdf (last visited Nov. 18, 2013) (John Bellinger, State Department legal advisor, remarking that "neither the text of the Convention [Against Torture], its negotiating history, nor the U.S. record of ratification supports a view that Article 3 of the CAT applies to persons outside the territory of the United States"). The CAT requires parties to undertake to prevent in any territory under its jurisdiction other acts of cruel, inhuman or degrading treatment or punishment which do not amount to torture as defined in Article 1. CAT, supra note 68, at art. 2(1).

132. See Human Rights Council, U.N. Joint Study on Global Practices in Relation to Secret Detention in the Context of Countering Terrorism, qा 99, 101 U.N. Doc. $\mathrm{A} / \mathrm{HRC} / 13 / 42$ (Feb. 19, 2010), available at http://daccess-ddsny.un.org/doc/UNDOC/GEN/G10/134/99/PDF/G1013499.pdf?OpenElement (last visited Nov. 21, 2013) (stating that the Bush Administration decided that human rights law would not apply in Afghanistan or in detention centers at Guantanamo Bay and other places around the world).

133. Paul A. Diller, When Congress Passes an Intentionally Unconstitutional Law: The Military Commissions Act of 2006, 61 SMU L. Rev. 281, 306 (2006); Rasul v. Bush, 124 S. Ct. 2686, 2698-99 (2004) (holding that overseas detainees could attain relief in U.S. courts for habeas corpus violations, and attain civil damages for international law violations). It is surprising that the Bush Administration utilized this ambiguous jurisdictional status because when the U.S. criminalized torture in 1994 for acts perpetrated by U.S. citizens outside the U.S., it was understood that the statute did not apply because Guantánamo Bay was "within the definition of the special maritime and territorial jurisdiction of the United States." Working Group Report on Detainee Interrogations in the Global War on Terrorism: Assessment of Legal, Historical, Policy, and Operational Considerations 7-8 (Apr. 4, 2003), available at http://www.washingtonpost.com/wpsrv/nation/documents/040403.pdf. (last visited Mar. 21, 2014).

134. Memorandum from Jack Goldsmith to William H. Taft, IV, et al. (Mar. 19, 2004), 


\author{
E. Classifying Combatants
}

\title{
1. Legal Advice
}

Based on advice from appointed lawyers, the Bush Administration announced that Taliban and al-Qaeda members were not entitled to POW status under the Geneva Conventions because of their combatant characteristics, but that they should be treated in a way that is consistent with the Geneva. ${ }^{136}$ Any combatant can be detained to prevent them "from returning to the field of battle and taking up arms once again," 137 but whether detainees are classified as POWs, civilian internees, or "other detainees," can set justifications for long-term detention, standards of treatment, and the right to prosecute. ${ }^{138}$ There is "pursuant to local immigration law" for a brief but not indefinite period, so long as adjudicative proceedings have not been initiated against them"). Alternatively, if a person is innocent, this could be a form of kidnapping, and if an individual is a combatant and one acknowledges that detainees are "protected" under the Geneva Conventions, they cannot be interrogated. Bejesky, Abu Ghraib Convictions, supra note 19, at 5-16 (noting the legal ambiguities that developed over treaty applicability in Iraq).

135. Dana Priest \& Dan Eggen, Terror Suspect Alleges Torture, THE WASH. Post (Jan. 6, 2005), available at http://www.washingtonpost.com/wp-dyn/articles/A517262005Jan5.html (last visited Nov. 21, 2013) (Gonzales affirmed the legal authorization for the U.S. to abduct terror suspects throughout the world without regard to foreign sovereignty). This can also be viewed as inconsistent with international law. Robert Bejesky, Sensibly Construing the "More Likely Than Not" Threshold for Extraordinary Rendition 6-7, 10-12 (Apr. 2013) (unpublished manuscript) [hereinafter Bejesky, Sensibly Construing].

136. Memorandum from Donald Rumsfeld, Secretary of Defense, to the Chairman of the Joint Chiefs of Staff (Jan. 19, 2002), available at http://www.defense.gov/news/Jun2004/d20040622doc1.pdf (last visited Nov. 19, 2013) (stating that al-Qaeda and the Taliban "are not entitled to prisoner of war status for purposes of the Geneva Conventions of 1949," but that soldiers should "treat them humanely, and to the extent appropriate and consistent with military necessity, [and] in a manner consistent with the Geneva Conventions of 1949"); Bush, supra note 101, at 9甲 2-3 ("[The U.S. military] shall continue to treat detainees humanely and, to the extent appropriate and consistent with military necessity, in a manner consistent with the principles of Geneva, [but] the Taliban [and al-Qaeda] detainees are unlawful combatants and, therefore, do not qualify as prisoners of war under Article 4 of Geneva.").

137. Hamdi v. Rumsfeld, 542 U.S. 507, 518 (2004).

138. See Deborah N. Pearlstein, Finding Effective Constraints on Executive Power: Interrogation, Detention, Torture, 81 IND. L.J. 1255, 1265 (2005) (noting that these classifications are also consistent with military doctrine); Int'l Comm. Red Cross, Commentary, Geneva Convention Relative to the Treatment of Prisoners of War, at art. 46 (1960) (affording protection to civilians and emphasizing that "protected persons" include 
disagreement over whether the correct designations under international law should be civilians and privileged combatants, ${ }^{139}$ meaning that anyone other than a combatant designee is by default a civilian. ${ }^{140}$ Instead, the Bush Administration invented a new category called "unlawful enemy combatant" to avoid Geneva Convention protections that prohibit interrogations ${ }^{141}$ and criminal prosecutions of captured combatants. ${ }^{142}$

OLC opinions even contended that torture should be narrowly construed and that prohibitions on interrogation did not apply to "enemy combatants."143 Unlawful detentions, prosecutions, or abuse during interrogations mandates liability under the Geneva Convention. ${ }^{144}$

"enemy nationals within the national territory of each of the Parties to the conflict and... the whole population of occupied territories").

139. Paul B. Stephan, Symmetry and Selectivity: What Happens in International Law When the World Changes, 10 CHI. J. INT'L L. 91, 104 (2009); Manooher Mofidi \& Amy E. Eckert, "Unlawful Combatants" or "Prisoners of War:" The Law and Politics of Labels, 36 CORNELL INT'L L.J. 59, 68-70 (2003) (noting that only legitimate combatants are entitled to POW status).

140. Geneva Protocol Additional, supra note 27, art. 50(1); Int'l Comm. Red Cross, Commentary on the Additional Protocols of 1977 to the Geneva Convention of 1949, 611 I 1917 (1987); ConVEntion (IV) RELATIVE to the Protection of CiVILIAN PERsons IN Time of War. Geneva, 12 August 1949, Commentary-Art. 4. Part I: General Provisions, available at http://www.icrc.org/ihl/COM/380-600007?OpenDocument (last visited Mar. 21,2014 ) ("Every person in enemy hands must have some status under international law: he is either a prisoner of war ... covered by the Third Convention, a civilian covered by the Fourth Convention, or ... a member of the medical personnel of the armed forces who is covered by the First Convention. There is no intermediate status; nobody in enemy hands can be outside the law.").

141. In THE NAME OF DEMOCRACY, supra note 17 , at 87,123 ; JEFFREY T. RiCHELSON, THE U.S. INTELLIGENCE COMMUNITY 307 (2012) (stating that "cheating" is the reason for Geneva rules that prohibit interrogations because POWs were a prime source of intelligence about adversaries in wars preceding the Geneva Conventions); George C. Harris, The Rule of Law and the War on Terror: The Professional Responsibilities of Executive Branch Lawyers in the Wake of 9/11, 1 J. NAT'L SECURITY L. \& POL'Y 409, 432-33 (2005) (noting that the OLC did not cite precedent for failing to apply any of the Geneva Convention categories).

142. Geneva I, supra note 27, art. 118 (POWs must be repatriated to their respective countries after hostilities end); Tug Yin, Ending the War on Terrorism One Terrorist at a Time: A Non Criminal Detention Model for Holding and Releasing Guantanamo Bay Detainees, 29 HARV. J.L. \& PuB. POL'Y 149, 171 (2005). Soldiers are generally not held liable for following orders, but there can be prosecutions for crimes against peace, war crimes, and crimes against humanity. Int'l Comm. of the Red Cross, Commentary of the Third Geneva Convention, 419-22 (1994).

143. David J. Barron \& Martin S. Lederman, The Commander in Chief at the Lowest Ebb - Framing the Problem, Doctrine, and Original Understanding, 121 HaRV. L. REV. 689, 707 (2008).

144. Geneva I, supra note 27 , art. 131 (no state "shall be allowed to absolve itself or any other ... of any liability incurred by itself or by another" for serious breaches of the 
Legal opinions written by Yoo, Delahunty and Gonzales focused much attention on the possibility of prosecution under the War Crimes Act, but " $[t]$ heir refutation of its applicability rests solely on the argument that the Third Geneva Convention does not protect members of the Taliban or al-Qaeda." 145

\section{Distinguishing Combatants}

There were two approaches for denying POW status for actions in Afghanistan based on the characteristics of the enemy. The first approach included applying Geneva Convention designation elements and the second approach involved pointedly determining that those deemed to be members of al-Qaeda and the Taliban were not protected.

First, advisory opinions assume that the Taliban and al-Qaeda were "unlawful enemy combatants" because they hid among civilians, ${ }^{146}$ which can deny POW status under Article 4(A) of the Third Geneva Convention because combatants (1) are not commanded by leaders, (2) do not wear recognizable combat insignia, (3) do not openly carry arms, and (4) do not obey laws of war. ${ }^{147}$ The test is intended to

\section{Geneva Convention).}

145. Wallach, supra note 56, at 619 ; Gonzales, supra note 70, at 1-2 (noting that if the Geneva Conventions do not apply to the Taliban, there was also a reduced likelihood of criminal prosecution of U.S. soldiers and officials under the War Crimes Act (18 U.S.C. 2441)); Benjamin G. Davis, Refluat Stercus: A Citizen's View of Criminal Prosecution in U.S. Domestic Courts of High-Level U.S. Civilian Authority and Military Generals for Torture and Cruel, Inhuman or Degrading Treatment, 23 ST. JoHN's J.L. Comm. 503, 57677 (2008).

146. 151 Cong. REC. S8811 (daily ed. July 25, 2005) (statement of Sen. Graham) ("They do not wear uniforms. They are terrorists. They hide among civilians. They cheat."); Yoram Dinstein, THE CONDUCT OF Hostilities UNDER THE LAW OF INTERNATIONAL ARMED CONFLICT 28-29 (2004) (stating that combatants who hide among civilians can lose the privileged status, and a civilian can become a combatant and vice versa).

147. Geneva I, supra note 27, art. 4(A)(1); see Hague Conventions on Land Warfare of 1899, ch. I, art. 1, July 29, 1899, 32 Stat. 1803; Hague Conventions on Land Warfare of 1907 , ch. I, art. 1, Oct. 18, 1907, 36 Stat. 2277; Bush, supra note 101, at 2; Bybee, supra note 51, at 9-10 (stating that al-Qaeda members "have attacked purely civilians targets of no military value; they refused to wear uniform or insignia or carry arms openly, but instead hijacked civilian airliners, took hostages, and killed them; and they themselves do not object the laws of war"). The problem with this position is that it discusses broad acts of al-Qaeda outside of Afghanistan and assumes culpability based on a perceived nexus that should have ultimately been dependent on determinations in military commissions at Guantánamo Bay. As of February 2013, "there have been six convictions of Guantánamo detainees by military commissions, four of which were procured by plea agreements." Jennifer K. Elsea, Cong. Research Serv., R40932, Comparison of Rights in Military Commission Trials and Trials in Federal Criminal Court 10 (2013), available at http://www.fas.org/sgp/crs/natsec/R40932.pdf (last visited Nov. 24, 2013). 
prevent rewarding combatants for hiding among civilians, which can place the civilians in harms way and provide an unfair military advantage if the opponent is conscientious in not placing civilians in danger. $^{148}$

On the one hand, the Taliban must have had some degree of structure and unity in command because it was engaged in fighting with the Northern Alliance for several years, but members would generally not meet the four elements. ${ }^{149}$ However, there are alternative interpretations of the Geneva Convention requirements that make denying POW status controversial. Article 44 of the Protocol Additional (adopted in 1977) provides that anyone "who falls in the power of an adverse party shall be a prisoner of war." 150 The U.S. is not a party to Protocol I, but 173 countries are members to make Protocol I an additional source to the Geneva Conventions, ${ }^{151}$ which might make Protocol I's POW principle customary international law. ${ }^{152}$

148. Jason Callen, Unlawful Combatants and the Geneva Conventions, 44 VA. J. INT'L L. 1025, 1026 (2004); Derek Jinks, The Changing Laws of War: Do We Need a New Legal Regime After September 11?: Protective Parity and the Laws of War, 79 Notre DAME L. REV. 1493, 1495 (2004) (noting that "the question is how best to encourage fighters to distinguish themselves from the civilian population").

149. United States v. Lindh, 212 F.Supp. 2d 541, 557-58 (E.D. Va. 2002); David E. Graham, The Treatment and Interrogation of Prisoners of War and Detainees, 37 GEo. J. INT'L L. 61, 69 (2005). Some commentators did contend that the Taliban was the armed forces of Afghanistan, but legal advisers called the Taliban a "loose confederation of militia groups." Graham, supra at 68 . The Taliban lacked an "organized command structure," and "wore the same clothes they wore to perform other daily functions." Memorandum from Assistant Attorney General Jay S. Bybee to White House Counsel Alberto R. Gonzales (Feb. 7, 2002), available at http://www.fas.org/irp/agency/doj/olc/taliban.pdf (last visited Nov. 11, 2013); 151 CoNG. REC. S8811 (daily ed. July 25, 2005) (statement of Sen. Graham) ("We find ourselves in a war with a group of people who are not part of a state or a nation. They do not wear uniforms. They are terrorists. They hide among civilians. They cheat."); Pierre-Richard Prosper, Ambassador-at-Large for War Crimes Issues, Remarks at the Chatham House on the Status and Treatment of Taliban and al-Qaeda Detainees (Feb. 20, 2002), available at $\mathrm{http}: / / 2001-2009$. state.gov/s/wci/us_releases/rm/2002/8491.htm (last visited Nov. 11, 2013) (identifying the elements for the test in the Geneva Conventions and agreeing that the Taliban do not meet the test to be granted POW status, but noting that they do "have the right to be treated humanely"); See contra Glazier, supra note 103, at 1013 (stating that some al-Qaeda units might have qualified as POWs because they did wear the same camouflage uniforms and openly carried weapons).

150. Int'l Comm. of the Red Cross, supra note 85.

151. Protocol Additional to the Geneva Conventions of 12 August 1949, and relating to the Protection of Victims of International Armed Conflicts (Protocol I), 8 June 1977, membership, available http://www.icrc.org/applic/ihl/ihl.nsf/States.xsp?xp_viewStates=XPages_NORMStatesParti es\&xp_treatySelected=470 (last visited Mar. 21, 2014).

152. Gregory E. Maggs, Terrorism And the Law: CaSes And Materials, app. c, at 585-87 (2005). 
During the negotiations over Protocol I, countries discussed terms to address liberation movements and to eliminate colonial powers from their countries and developing countries prevailed in eliminating the insignia requirement ${ }^{153}$ so that hostilities could be conducted from within civilian populations and belligerents would still have POW status. ${ }^{154}$ Protocol I adds that "armed forces of a Party" comprise "all organized armed forces, groups and units which are under a command responsible to that Party for the conduct of its subordinates." "I55 If the Taliban could be granted POW status and there is a sufficient relationship between the Taliban and al-Qaeda, ${ }^{156}$ then both groups could have arguably received POW status.

Article 44(3) of the Protocol Additional to the Geneva Convention states that a combatant is not required to wear a uniform when "owing to the nature of the hostilities an armed combatant cannot so distinguish himself." 157 The invasion of Afghanistan occurred due to the acts of 19 hijackers, reportedly because of a plan devised by Osama bin Laden, who was apparently in Afghanistan. The Taliban did not direct those who were involved in $9 / 11^{158}$ and perhaps those wielding weapons against invading forces acted in self-defense when

153. Geneva Protocol Additional, supra note 27, art. 44(3); see also Geneva I, supra note 27, art. 4(A)(1),(2) (POW status is applicable to "members of the armed forces of a Party" and "organized resistance movements").

154. Richard D. Rosen, Targeting Enemy Forces in the War on Terror: Preserving Civilian Immunity, 42 VAND. J. TRANSNAT'L L. 683, 724-26 (2009).

155. Geneva Protocol Additional, supra note 27, art. 43(1); INTL. COMM. OF THE RED Cross, supra note 140, I 1663, at 508 (non-state entities "may in certain circumstances become Parties to the conflict").

156. John Yoo, Fixing Failed States, 99 CALIF. L. Rev. 95, 108 (2011) (stating that it "appears now that either the Taliban could not control al-Qaeda, or that al-Qaeda simply dictated to the Taliban"); Stephen R. Shalom, Far From Infinite Justice: Just War Theory and Operation Enduring Freedom, 26 ARIZ. J. INT'L \& COMP. L. 623, at 644 (emphasizing that CIA Director George Tenet considered al-Qaeda and the Taliban inseparable). Not all agree that there was this tight relationship. Rachael Lorna Johnstone, Unlikely Bedfellows: Feminist Theory and the War on Terror, 9 CHI.-KENT J. INT'L \& COMP. L. 1 (2009) (reporting that "[l]inks between the Taliban and al-Qaeda go beyond the mere territorial, but nonetheless are a far cry from the threshold of complete dependence or effective control applied in the Nicaragua Judgment," which assessed the relationship between the Contras and the Reagan Administration's covert action team); Vincent-Joel Proulx, If the Hat Fits, Wear It, If the Turban Fits, Run for your Life: Reflections on the Indefinite Detention and Targeted Killing of Suspected Terrorists, 56 HASTINGS L.J. 801, 840 (2005) (noting that the Taliban did not seem to have any greater connection to al-Qaeda than providing logistical support).

157. Geneva Protocol Additional, supra note 27, art. 44(3).

158. Reinold, supra note 74 , at 245 (noting that "the Afghan Taliban...neither directed nor controlled the perpetrators of $9 / 11$ "). 
confronted. ${ }^{159}$ There may also be some hypocrisy in not granting POW status ${ }^{160}$ and Afghanistan's poverty may have made procuring uniforms cost prohibitive. ${ }^{161}$

The second general approach for denying POW protections was to assume that if individuals could be labeled members of the Taliban and or al-Qaeda, they would be designated an "enemy combatant."162 "Membership" is the determining variable for an "enemy combatant" designation, rather than the act perpetrated that preceded capture. Many authorities disagreed with the use of the "unlawful enemy combatant" label to deny Geneva Convention protections in Afghanistan, ${ }^{163}$

159. Shalom, supra note 156 , at $672,674-75$ (mingling with civilians does not absolve the U.S. of responsibility to avoid harming non-combatants, but early NGO estimates placed Afghani civilian casualties at several thousand).

160. Geneva Protocol Additional, supra note 27, art. 44(4) (stating that even if a combatant does not meet POW requirements or carry arms openly, the individual will "nevertheless, be given protections equivalent in all respects to those accorded to prisoners of war"); Scott M. Sullivan, Private Force / Public Goods, 42 ConN. L. REv. 853, 878 (2010) (noting that some American government officials disclosed that private military contractors for some types of operations were advantageous because they do not wear uniforms). Given that CIA operations are often covert, CIA agents and assets also do not wear uniforms and may commingle with civilian populations.

161. World Bank, Int'l Dev. Ass'n, Operational Pol'y \& Country Serv. \& Res. Mobilization Dep'T, Operational Approaches and Financing in Fragile States 2 (June 2007) (depicting Afghanistan as the eighth poorest country in the world and the poorest outside of Africa).

162. Guantanamo Detainee Process, DeP'T OF DEF., at 2 (Oct. 2, 2007), available at http://www.defense.gov/news/Sep2005/d20050908process.pdf (last visited Sept. 24, 2013) (stating that for purposes of detention at Guantánamo, an "enemy combatant" is "an individual who was part of or supporting Taliban or al-Qaeda forces, or associated forces that are engaged in hostilities against the United States or its coalition partners. This includes any person who has committed a belligerent act or has directly supported hostilities in aid of enemy armed forces."); Memorandum from William J. Haynes II, Gen. Counsel of the Dep't of Def., to Members of the ASIL-CFR Roundtable (Dec. 12, 2002), available at http://www.cfr.org/international-law/enemy-combatants/p5312 (last visited Sept. 24, 2013) (defining an "enemy combatant" as "an individual who, under the laws and customs of war, may be detained for the duration of an armed conflict. In the current conflict with al Qaida and the Taliban, the term includes a member, agent, or associate of al-Qaida or the Taliban."); see also Memorandum from LTC Diane Beaver, Staff Judge Advocate, to Commander, Joint Task Force 170, at Legal Brief on Proposed Counter-Resistance Strategies, para. 2 (Oct. 11, 2002), reproduced in ThE TORTURE PAPER: THE ROAD TO ABU GhrAIB 229 (Karen J. Greenberg \& Joshua L. Dratel eds., 2005) ("Since the detainees are not [Enemy Prisoners of War] EPWs, the Geneva Conventions limitations that ordinarily would govern captured enemy personnel interrogations are not binding on U.S. personnel conducting detainee interrogations at GTMO.”); Ensign Scott L. Glabe, Conflict Classification and Detainee Treatment in the War Against al Qaeda, 2010 ARMY L. 112, 113-15 (noting that there was difficulty in classifying operations against al-Qaeda under the Geneva Convention).

163. Paust, supra note 5, at 829 (pointing out that the Bush White House's use of the 
extenuate precedent, confuse the categories, ${ }^{164}$ and to use Geneva Convention definitions not to classify the enemy, but to use characteristics of the enemy to construct a new category.

"Enemy combatant" was not a commonly-used term prior to $9 / 11$, and there is no reason to believe it was legitimate in this case. ${ }^{165}$ In Ex parte Quirin (1942), the Supreme Court called six German saboteurs caught on U.S. shores during World War II unlawful enemy combatants. ${ }^{166}$ The Court pointed out that they were not qualified to be POWs because they, "during time of war, pass surreptitiously from enemy territory into our own, discarding their uniforms upon entry, for the commission of hostile acts ..."167 If the intent with using the term was to assume that those individuals who entered U.S. territory during a world war with an intention to commit terrorism should be extrapolated to anyone inside a foreign country that the U.S. invaded, the factual comparison is spurious.

After much debate over the classification of those detained in Afghanistan, in January 2005, the Bush Administration finally declassified the legal memo that stated that there was an intention to treat members of the Taliban and al-Qaeda in a manner consistent with the Geneva Conventions. ${ }^{168}$ It is unclear why compliance with international law should be a classified national secret and it is unclear whether this intention was in fact fulfilled in the previous years. The

term "unlawful combatant" "demonstrate[d] remarkable ignorance of the nature and reach of treaties and customary international law ... [because] any member of al-Qaeda who is a national of a state that has ratified the relevant treaties is protected by them."); Hamdi v. Rumsfeld, 542 U.S. 549 (2004) (Souter, J., concurring) (disagreeing with classifying the Taliban as unlawful enemy combatants). The Canadian military commented on treatment of detainees in Afghanistan: "All the individuals ...captured or detained will be afforded humane treatment, according to the standards that are applicable to POWs, and that's according to international law." Hendin, supra note 78, at 61 .

164. David Wippman, Comment on Richard Arneson's Just Warfare Theory and Noncombatant Immunity, 39 CORNELL INT'L L.J. 699, 702 (2006) (noting that the proper term should have been "unprivileged belligerent").

165. Peter Jan Honigsberg, Inside Guantanamo, 10 NEV. L.J. 82, 94 (2010).

166. Ex parte Quirin, 317 U.S. 1, 30-31 (1942) (noting that they were individuals associated with a country at war with the U.S. and who would engage in acts that would support the enemy).

167. Id. at 31,35 (holding that an unlawful enemy combatant can be a "spy who secretly and without uniform passes the military lines of a belligerent in a time of war, seeking to gather military information and communicate it to the enemy ...").

168. Scharf, International Law in Crisis, supra note 17, at 85; Laura A. Dickinson, Military Lawyers on the Battlefield: An Empirical Account of International Law Compliance, 104 AM. J. INT'L L. 1, 14 (2010) (stating that a new U.S. Army Field Manual was adopted in 2006 and eliminated classifications between Prisoners of War and enemy combatants and provided that the Geneva Conventions apply to all detainees). 
definitional maneuvers in Afghanistan were astonishingly parallel to what transpired in Iraq.

The Bush Administration acknowledged that the Geneva Conventions clearly applied in Iraq, ${ }^{169}$ but for some reason Iraqi detainees were subjected to the same incarceration and interrogation policies and many were also called "unlawful combatants." 170 Security Council Resolution 1483 pertained to the occupation of Iraq and cited the Geneva Conventions of 1949 and the Hague Regulations of 1907 as applicable during the occupation. ${ }^{171}$ The Supreme Court regards the Hague Conventions, which have been ratified by over 180 countries, as the paramount authority for assessing proper conduct for the law of war, ${ }^{172}$ and Geneva Convention protections should also apply as a matter of customary international law. ${ }^{173}$ The Bush Administration simply rejected the Conventions and Security Council Resolution restrictions in the case of Iraqi detainees. Rumsfeld directed intensive interrogation procedures to obtain "actionable intelligence" from Iraqi

169. See, e.g., Dep't of Defense News Transcript, Secretary Rumsfeld Media Availability En route to Baghdad (May 13, 2004), available at http://www.defense.gov/transcripts/transcript.aspx?transcriptid=3010 (last visited Nov. 13, 2013) (Rumsfeld stating that "from the beginning" it has been the U.S. government's position "with respect to Iraq that the Geneva Conventions apply" and "anyone who is running around saying that Geneva Convention did not apply in Iraq is either terribly uninformed or mischievous."). In congressional hearings, Senator Levin stated that Rumsfeld publicly announced about Iraq on several occasions "that the Geneva Conventions apply not precisely, that prisoners are treated 'consistent with, but not pursuant to' [the Geneva Conventions]." Review of Department of Defense Detention and Interrogation Operations, Hearing on S. 108-868 Before the Comm. on Armed Serv., 108 ${ }^{\text {th }}$ Cong. (2004), available at http://www.gpo.gov/fdsys/pkg/CHRG-108shrg96600/html/CHRG108shrg96600.htm (last visited Nov. 13, 2013) [hereinafter "Comm. on Armed Serv."].

170. Comm. on Armed Serv., supra note 169 (Colonel Warren stating that some detainees at Abu Ghraib were being called "unlawful combatants" and that interrogation procedures "are not, in and of themselves, in isolation, violations of the Geneva Conventions," specifically for "security detainees" under the Fourth Convention). Senator Levin itemized interrogation methods approved by Rumsfeld for "unlawful combatants" in December 2002, and methods included "nudity, exploiting detainees' fears . . and stress positions." Id. Additional interrogation methods were authorized on April 16, 2003. Id. General Miller provided interrogation orders when visiting Iraq; "Policy No. 1-Battlefield Interrogation Team and Facility (BIT/F) Policy" dated 15 July 2003 was produced for Iraq, and queried General Fay who admitted that these authorizations "contribute[d] to the use at Abu Ghraib of aggressive interrogation techniques ..." Id.

171. S.C. Res. 1483, ๆ 5, U.N. Doc. S/RES/1483 (May 22, 2003).

172. See Hamdan, 548 U.S. at 603-04; Hamdi, 542 U.S. at 520; Kadic v. Karadzic, 70 F.3d 232, 242-43 (2d Cir. 1995); United States v. Yunis, 924 F.2d 1086 (D.C. Cir. 1991).

173. Glabe, supra note 162, at 116. Germany did not ratify the 1907 Hague Convention, but violations were applied as customary international law. International Military Tribunal at Nuremberg, Judgment and Sentences, Oct. 1, 1946, reprinted in 41 АM. J. INT'L L. 172, 248-49 (1947). 
prisoners ${ }^{174}$ and originally justified issuing the interrogation directives as necessary methods to fight the "war on terror"175 even though Hussein's regime did not have ties to al-Qaeda. ${ }^{176}$

\section{F. Using Interrogators and Classifying Torture}

\section{International Law Prohibits Interrogation}

With legal advice postulating that international law did not restrict the Bush Administration's directives under the Commander-inChief authority, that the Geneva Conventions did not apply because Afghanistan was a failed state, that the conflict was international but the Conventions were not binding and Article 3 was inapplicable, and that those categorized as "unlawful enemy combatants" could be denied POW protection, it certainly does appear that appointed legal advisers strove to meet an ultimate goal of detaining and interrogating prisoners without legal ramification. These contentions molded the groundwork for what was explicated more directly by White House Counsel Alberto Gonzales. The existence of "novel factual circumstances" does not

174. In the Name of Democracy, supra note 17, at 121; Scott Higham \& Joe Stephens, New Details of Prison Abuse Emerge, WASH. Post, May 21, 2004, at A01 (recalling the abuse at Abu Ghraib, stating that interrogations were being used to obtain intelligence to "thwart the insurgency in Iraq" and "find Saddam Hussein or locate weapons of mass destruction," and that military intelligence officers were using "MPs to help "set the conditions' for interrogation"); R. Jeffrey Smith, Knowledge of Abusive Tactics May Go Higher, WASH. POST, May 16, 2004, at A01 (stating that there was "heightened pressures in Washington for more robust intelligence-gathering, because of proliferating attacks on U.S. forces and the dwindling intelligence on Saddam Hussein's suspected weapons of mass destruction").

175. In the NAME OF DemOcracy, supra note 17, at 94, 122, 126-27; JAMES R. SCHLESINGER ET AL., FinAl REPORT OF THE INDEPENDENT PANEL TO REVIEW DEPARTMENT OF DEFENSE DETENTION OPERATIONS 63-64 (2004), available at http://www.defense.gov/news/aug2004/d20040824finalreport.pdf (last visited Nov. 13, 2013) (stating that interrogation was being used to gather intelligence and that the "failure to adapt rapidly to the new requirements of the Global War on Terror resulted in inadequate resourcing, inexperienced and untrained personnel, and a backlog of detainees destined for interrogation."); HuMAN RIGHTS WATCH, THE ROAD TO ABU GHRAIB 1 (2005), available at http://www.hrw.org/sites/default/files/reports/usa0604.pdf (last visited Nov. 13, 2013) (stating that "the Bush administration... required that the United States circumvent international law ... " and administration lawyers counseled that "the new war against terrorism rendered 'obsolete' long-standing legal restrictions on the treatment and interrogation of detainees.").

176. See generally Bejesky, CFP, supra note 110; Robert Bejesky, Intelligence Information and Judicial Evidentiary Standards, 44 CREIGHTON L. REV. 811, 858-59, 877 (2011) [hereinafter "Bejesky, Intelligence Information"]. 
mean that government officials can dismiss existing law, ${ }^{177}$ but Gonzales opined that the war on terrorism required a "new paradigm" that rendered "obsolete Geneva's strict limitations on questioning of enemy prisoners" because of the need to "quickly obtain information from captured terrorists and their sponsors." 178 As a categorical prohibition without exceptions ${ }^{179}$ and with similar restrictions existing in U.S. military law for 150 years, ${ }^{180}$ Article 17 of the 1949 Geneva Convention provides:

Every prisoner of war, when questioned on the subject, is bound to give only his surname, first names and rank, date of birth, and army, regimental, personal or serial number, or failing this, equivalent information. . .No physical or mental torture, nor any other form of coercion, may be inflicted on prisoners of war to secure from them information of any kind whatever. Prisoners of war who refuse to answer may not be threatened, insulted, or exposed to any unpleasant or disadvantageous treatment of any kind. ${ }^{181}$

The Geneva Convention mandates that prisoners of war be humanely treated at all times and requires states to prohibit actions that cause death, seriously endanger the health of prisoners, or subject detainees to acts of violence, reprisals, intimidation, or "any other form

177. Hope v. Pelzer, 536 U.S. 730, 741 (2002).

178. Gonzales, supra note 70, at 2; HuMAN Rights WATCH, supra note 175, at 1.

179. Bassiouni, supra note 16 , at 395.

180. Department Of the ARmy Field Manual 34-52, Intelligence Interrogation, at $1-8$ (1992), available at http://www.fas.org/irp/doddir/army/fm3452.pdf\#search=\%22FM\%2034-52\%20Field\%20Manual\%22 (last visited Nov. 19, 2013) (stating that "[p]hysical or mental torture and coercion revolve around eliminating the source's free will ... Torture is defined as the infliction of intense pain to body or mind to extract a confession or information, or for sadistic pleasure," and "US policy expressly prohibits acts of violence or intimidation, including physical or mental torture, threats, insults, or exposure to inhumane treatment as a means of or aid to interrogation."); U.S. WAR DEP'T, INSTRUCTIONS FOR THE GOVERNMENT OF ARMIES OF THE UNITED STATES IN THE FIELD, SECTION I, ART. 16 (1863), available at http://www.icrc.org/ihl.nsf/0/286696dfc21d967ec12563cd00514a91?OpenDocument (last visited Nov. 19, 2013) (noting that the 1863 Instructions for the Government of Armies of the United States (Lieber Code) stated that "[m]ilitary necessity does not admit of crueltythat is, the infliction of suffering for the sake of suffering or for revenge, nor of maiming or wounding except in fight, nor of torture to extort confessions"); see also David Luban, Liberalism, Torture, and the Ticking Bomb, 91 VA. L. REV. 1425, 1435 (2005); BLACK's LAW DiCTIONARY 1528 (8th ed. 2004) (defining torture as "the infliction of intense pain to the body or mind to punish, or to extract a confession ... or to obtain sadistic pleasure").

181. Geneva I, supra note 27, at art. 17; Aaron E. Garfield, Note: Bridging a Gap in Human Rights Law: Prisoner of War Abuse as “War Tort," 37 GEO. J. INT'L L. 725, 748-49 (2006). 
of coercion" to attain information, ${ }^{182}$ but these conditions were systematically violated in Iraq, Afghanistan, and Guantánamo Bay. ${ }^{183}$ Geneva Convention provisions require prisoners to be given adequate food and water to maintain good health, sufficient clothing and footwear, sanitary facilities, and medical attention, ${ }^{184}$ but the Bush Administration overtly violated convention provisions by issuing directives that upset detainees' psychological and physical conditions, stripped them naked, and tasked health care professionals to facilitate interrogations. $^{185}$

\section{Distinguishing Between Torture and Cruel and Inhuman Treatment}

As for the degree of abuse, trends and policy intentions indicate that there should be no sharp distinction between torture and cruel and unusual punishment, ${ }^{186}$ but legal advisors issued memos that sustained the use of harsh interrogations by obfuscating distinctions between torture and cruel, inhuman, or degrading punishment. ${ }^{187}$ These prohibitions on interrogation are applicable during a period of armed

182. Geneva I, supra note 27, arts. 13, 17.

183. Bejesky, Abu Ghraib Convictions, supra note 19, at 17-31, 60-64; Bejesky, Epiphany Approach, supra note 4, at 6-11, 20-25.

184. Geneva I, supra note 27, arts. 26-30.

185. Bejesky, Abu Ghraib Convictions, supra note 19, at 35-36.

186. Koh, supra note 69 , at 642 ("Torture and cruel, inhuman, and degrading treatment are both illegal and totally abhorrent to our values and constitutional traditions. And no constitutional authority licenses the President to authorize the torture and cruel treatment of prisoners, even when he acts as Commander-in-Chief."); ABA Torture Resolution 10-B, at 1 (adopted Aug. 9, 2004), available at http://www.americanbar.org/content/dam/aba/migrated/poladv/priorities/torture/torturepolic y2004_10B.authcheckdam.pdf (last visited Nov. 19, 2013) (condemning "any use of torture or other cruel, inhuman or degrading treatment or punishment upon persons within the custody or under the physical control of the United States government... and any endorsement or authorization of such measures by government lawyers."). International law can be interpreted to absolutely prohibit interrogation and all forms of abuse. Geneva I, supra note 27 , at art. 17 (stating that "[n]o physical or mental torture, nor any other form of coercion" can be employed); Bejesky, Pruning, supra note 4, at 829-36.

187. See John T. Parry, Escalation and Necessity: Defining Torture at Home and Abroad, in TORTURE: A COLLECTION 154 (Sanford Levinson, ed., 2004); Waldron, supra note 97, at 1727 (the administration was obfuscating "cruel, inhuman and degrading methods" from "torture for the purpose of paying lip service to prohibitions"); US Experts Unconvinced by Bush Assurance on Torture, REUTERS (June 25, 2004), available at http://www.commondreams.org/headlines04/0625-07.htm (last visited Nov. 19, 2013) (Republican representative Frank Wolf wrote a letter to the Justice Department noting: "I am deeply concerned that this memorandum provides legal justification for the US government to commit cruel, inhumane and degrading acts, including torture."). 
combat, occupation, ${ }^{188}$ and as general restrictions that prohibit any substantial level abuse by government agents in other locations. ${ }^{189}$

With several bodies of law applicable in different contexts and locations to prohibit interrogation that would be torture or cruel, inhuman, or degrading treatment, another of the Bush Administration's approaches was to discount the applicability of generally restrictive sources by referencing exceptions in one source. For example, specifically to imprison and interrogate detainees at Guantánamo Bay, the Administration contended that Articles 1-27 of the International Covenant on Civil and Political Rights (ICCPR) did not bind U.S. actions because the ICCPR was not self-executing as domestic law, could not be enforced in American courts, and that the President could dismiss restrictions based on exigency. ${ }^{190}$

The ICCPR distinguishes between torture and lesser forms of harm and absolutely prohibits torture, but "cruel, inhuman or degrading treatment or punishment" could be permitted if there is a sufficient

188. Geneva I, supra note 27 , art. 3 (grave breaches of the laws of war include "murder of all kinds, mutilation, cruel treatment and torture; ... outrages upon personal dignity, in particular, humiliating and degrading treatment; [and] the passing of sentences and the carrying out of executions without previous judgment."); Paust, supra note 5, at 835 (noting that during an occupation, the Geneva Convention and human rights law prohibit torture, “"violence,' threat of violence, 'cruel' treatment, 'physical and moral coercion . . .to obtain information,' 'physical suffering,' 'inhuman' treatment, 'degrading' treatment, 'humiliating' treatment, and 'intimidation' during interrogation").

189. CAT, supra note 68 , art. 1 (prohibiting "any act by which severe pain or suffering, whether physical or mental, is intentionally inflicted on a person" for reasons of inflicting severe physical or mental pain or punishment, intimidating, inflicting punishment, or extracting information); Universal Declaration of Human Rights, G.A. Res. 217, U.N. GAOR, 3d Sess., art. 5, U.N. Doc. A/810 (1948) ("No one shall be subjected to torture or to cruel, inhuman or degrading treatment or punishment"); Body of Principles for the Protection of All Persons under Any Form of Detention or Imprisonment, Principle 6, G.A. Res. 43/173, Annex, U.N. GAOR, 43d Sess., Supp. No. 49, U.N. Doc. A/43/49 (Dec. 9, 1988) (providing that "no person under any form of detention or imprisonment shall be subject to torture or to cruel, inhuman or degrading treatment or punishment"); European Convention, supra note 125, art. 3 (defining torture as "any act by which severe pain or suffering, whether physical or mental, is intentionally inflicted on a person for such purposes as obtaining from him or a third person information or a confession, punishing him ... , or intimidating or coercing him"); Michael John Garcia, The U.N. Convention Against Torture: Overview of U.S. Implementation Policy Concerning the Removal of Aliens 1, CRS REPORT FOR CONGRESS, Mar. 11, 2004, available at http://fpc.state.gov/documents/organization/31351.pdf (last visited Nov. 19, 2013) (noting that "torture is defined as an extreme form of cruel and unusual punishment committed under the color of law" and that the U.S. enacted statutes to enforce Article 3).

190. Amnesty International, DeCADE of Damage to Human Rights 45 n.10 (2011), available at http://www.amnesty.ca/sites/default/files/2011-1216amr51103201 lenguantanamodecadeofdamage.pdf (last visited Nov. 19, 2013). 
exigency. ${ }^{191}$ The ICCPR is not automatically suspended during a period of armed combat, such that combat would be deemed an exigency, ${ }^{192}$ and Article 9 only permits temporary derogations "to the extent strictly required by the exigencies of the situation" and only when member states officially request exemptions. ${ }^{193}$ Moreover, the ICCPR Committee defined torture broadly, such as by noting that sleep deprivation, ${ }^{194}$ forcing captives into stress positions, hooding, and threatening detainees were forms of torture. ${ }^{195}$

The Administration was indeed correct when it reminded that at the time of congressional ratification, the ICCPR was not intended to be self-executing. ${ }^{196}$ However, the Senate made a reservation to the ICCPR based on prohibiting torture as standards equivalent to cruel,

191. Comm. on Int'l Human Rights, The Convention Against Torture and Other Cruel, Inhuman or Degrading Treatment or Punishment, 42 REC. OF THE Ass'N OF THE BAR OF THE CITY OF N.Y. 235, 240 (1987) (explaining that "most of the obligations imposed by the Convention apply only to acts of torture, as defined in Article 1"); AMNESTY INTERNATIONAL, supra note 190, at 45 n.10 (stating that the advisory memo "entirely ignored the fact that under the ICCPR, even 'in time of public emergency which threatens the life of the nation', there can be no derogation from the prohibition of cruel, inhuman or degrading treatment or punishment (Articles 4 and 7)").

192. van Aggelen, supra note 108, at 56.

193. ICCPR, supra note 116, at art. 9; Human Rights Comm., CCPR General Comment No. 29: Article 4: Derogations during a State of Emergency, 72nd Sess., Aug. 31, 2001, U.N. Doc. CCPR/C/21/Rev.1/Add.11, I 2 (Aug. 31, 2001), available at http://www.refworld.org/docid/453883fdlf.html (last visited Nov. 19, 2013) (affirming that "[m] easures derogating from the provisions of the Covenant must be of an exceptional and temporary nature").

194. See Office of the High Comm'r for Human Rights [OHCHR], Comm. Against Torture, Annual Rep., Sept. 10, 1997, U.N. Doc. A/52/44; GAOR, 52nd Sess., Supp. No. 44, $\uparrow 257$ (Sept. 10, 1997).

195. Human Rights Comm., $31^{\text {st }}$ Sess., Oct. 26-Nov. 13, 1987, U.N. Doc. A/43/40, ๆๆ 2.2, 4, $10 \quad$ (Oct. $27, \quad$ 1987), available at http://www.worldcourts.com/hrc/eng/decisions/1987.10.27_Magri_de_Cariboni_v_Uruguay .htm (last visited Oct. 1, 2013) (being kept incommunicado for 42 days, "blindfolded with towelling material," deprived of sleep, beaten, and threatened with torture, was torture); Human Rights Comm., 60 ${ }^{\text {th }}$ Sess., July 29, 1997, U.N. Doc. CCPR/C/60/D/612/1995, 98.5 (July 29, 1997), available at http://www.bayefsky.com/html/114_colombia053.php (last visited Oct. 1, 2013) (stating that "being blindfolded and dunked in a canal" and being threatened with deadly force were torture).

196. U.S. Senate Resolution of Advice and Consent to Ratification of the International Covenant on Civil and Political Rights, 138 ConG. REC. 8070 (1992) (specifying that "the United States declares that the provisions of Articles 1 through 27 of the [ICCPR] are not self-executing"); Senate Committee on Foreign Relations Report on the International Covenant on Civil and Political Rights, S. Exec. Rep. 102-23, 31 I.L.M. 645, 652, 657 (1992) (stating that " $[t]$ he Administration proposed a declaration stating that Articles 1 through 27 of the [ICCPR] are not self executing" and that "[t]he intent is to clarify that the [ICCPR] will not create a private cause of action in U.S. courts"). 
unusual, and inhumane treatment as specified in the Fifth, Eight, and/or Fourteenth Amendments to the Constitution, ${ }^{197}$ which means that U.S. jurisprudence and law enforcement practices in the U.S. are applicable to defining torture and that "the Convention bans conduct that is already unconstitutional."198 The White House and Secretary of Defense directed the use of psychological interrogation tactics that American officials could not engage in inside the U.S. without violating the Eighth Amendment and those same standards would be prohibited outside the United States when the ICCPR or CAT are applicable to American government actions. ${ }^{199}$

\section{Endorsing Specific Methods}

With respect to the interrogation tactics that the Bush Administration approved, in October 2002, Joint Task Force 170 furnished the Joint Chiefs of Staff and SOUTHCOM with proposals that were substantially similar to interrogation methodology that the CIA

197. 136 CoNG. REC. 25, 36, 192 (1990) (the U.S. is bound to prevent “"cruel, inhuman or degrading treatment or punishment' only insofar as the term . . .means the cruel, unusual and inhumane treatment or punishment prohibited by the Fifth, Eighth, and/or Fourteenth Amendments to the Constitution of the United States"); U.S. DEP'T. OF DEF., WORKING Group REPORT ON DETAINEE INTERrogations IN THE Global WAR ON TERrorism: AsSessment OF Legal, Historical, Policy, and Operational CONSIDERATIONS 6 (Apr. 4, 2003), available at http://www.gwu.edu/ nsarchiv/NSAEBB/NSAEBB127/03.04.04.pdf (last visited Nov. 9, 2013) (stating that U.S. obligations "under the Torture Convention apply to the interrogation of unlawful combatant detainees," but only to the extent that "cruel, inhuman, and degrading treatment and punishment" was restricted under the U.S. Constitution; ICCPR, supra note 116 , art. 7 ("cruel, inhuman or degrading treatment or punishment" restriction as equated to cruel and unusual treatment in the Bill of Rights); Garcia, supra note 189, at 2, 4 (stating that police brutality would not be torture under the CAT, but distinguishing from the lesser forms of "cruel and unusual punishment" and affirming that both standards are prohibited); Id. at 6 (stating that there the Senate restricted "mental torture" to mean "severe physical pain and suffering"); LOUIS HENKIN, INTERNATIONAL LAW CASES AND MATERIALS 626 (3d ed. 1993) ("The reasons why the United States has maintained its distance from the international human rights agreements are not obvious. . [T]here is resistance to accepting international standards, and international scrutiny, on matters that have been for the United States to decide.").

198. Evil, Law and the State: Perspectives on State Power and Violence 9 (John T. Parry ed., 2006).

199. Garcia, supra note 189 , at 13 (CAT and/or $\S 2340$ A restricts torture outside the U.S. borders). Congress ensured that this was clear with the McCain Amendment which affirms that the President must "take action to ensure" that "[n]o individual in the custody or under the physical control of the United States Government, regardless of nationality or physical location, shall be subject to cruel, unusual, and inhumane treatment and punishment prohibited by the U.S. Constitution.” 42 U.S.C. $\S \S 2000 \mathrm{dd}(\mathrm{d}), 2000 \mathrm{dd}-0$ (3) (2008). 
researched and incorporated into its Kubark Interrogation Manual in $1963 .^{200}$ The Task Force proposed three categories of techniques with progressing intensity. Category I authorized interrogators to stimulate an uncomfortable environment by yelling and employing deception to create stress. $^{201}$ Category II permitted interrogators to use stress positions, produce falsified documents, quarantine captives in solitary confinement for up to thirty days, restrict breathing, induce sensory deprivation, and invoke phobias. ${ }^{202}$ Category III authorized interrogators to threaten to kill members of a captive's family, expose inmates to harshly cold temperatures and water, engage in daylong interrogations, and induce perceptions of drowning or suffocation. ${ }^{203}$ In December 2002, Defense Secretary Rumsfeld approved Category I and II, and some methods in Category III. ${ }^{204}$

After some officials contended that detainees frequently resisted approved interrogation methods, in early March 2003, a Defense Working Group proposed more approaches and Rumsfeld authorized another dozen interrogation techniques, including implementing "environmental manipulation," altering sleep rhythms from night to day, leaving detainees naked in dark isolation for up to thirty days, applying harsh heat and cold, withholding food, hooding for several days straight, and forcing detainees into "stress positions" that would "subject detainees to rising levels of pain." 205 Directives progressed down the chain of command and interrogators commonly used the procedures on detainees at all American detention facilities. ${ }^{206}$

200. Wallach, supra note 56, at 581 .

201. See generally Memorandum from General Counsel of the Department of Defense William J. Haynes II for Secretary of Defense (Nov. 27, 2002), available at http://www.dod.mil/pubs/foi/operation_and_plans/Detainee/additional_detainee_documents/ 07-F-2406\%20doc\%201.pdf (last visited Nov. 9, 2013); Memorandum from Joint Task Force 170 for Commander, U.S. Southern Command (Oct. 11, 2002), available at http://www.defense.gov/news/Jun2004/d20040622doc3.pdf (last visited Nov. 9, 2013) [hereinafter Task Force 170].

202. Task Force 170, supra note 201, at 1-2.

203. Id. at 2-3.

204. Wallach, supra note 56, at 583, 593-94; Paust, supra note 5, at 840 . In November 2002, the Bush Administration approved the use of sensory deprivation, stress positions, phobias and dogs, psychological trickery, and threat scenarios against the detainee and/or his family. Haynes, supra note 201.

205. U.S. DEP'T OF DEF., supra note 197, at 2, 63-65, 70.

206. LTG Anthony R. Jones, AR 15-6 Investigation of the Abu Ghraib Prison and $205^{\text {th }}$ Military Intelligence Brigade, FindLAw.COM 10, 15-16, 25-26 (August 23, 2004), available at http://fll.findlaw.com/news.findlaw.com/hdocs/docs/dod/fay82504rpt.pdf (last visited Nov. 19, 2013) (noting that on September 14, 2003, Lt. Gen. Ricardo Sanchez, authorized the use of twenty-nine interrogation methods in Iraq, including isolation, stress 
There was emphatic criticism of these methods, which led to disagreements with international authorities. The Bush Administration offered retorts with a failure to recognize the degree of abuse. For example, expressing concerns over the isolation of prisoners, the United Nations Human Rights Council stated that the "weight of accumulated evidence to date points to the serious and adverse health effects of solitary confinement" and that it was a potential breach of the ICCPR. ${ }^{207}$ The Bush Administration denied that "prolonged isolation and indefinite detention ... per se constitutes cruel, inhuman, or degrading treatment or punishment."208 Yet with the ICCPR's usual applicability to domestic criminal law standards, there is a general distinction between placing an already-convicted inmate in solitary confinement perhaps for a week as a punishment for misbehaving in a penal facility, and capturing a suspected insurgent or terrorist, blindfolding him, taking him to an unknown location, and subjecting him to other forms of sensory deprivation and isolation for weeks or months without being certain about the detainee's guilt.

The ECHR deemed methods such as "wall-standing, hooding, subjection to noise, deprivation of sleep, and deprivation of food and drink," inhuman treatment that caused "at least intense physical and mental suffering." 209 The methods were explicitly prohibited under the ECHR, but they were not deemed torture. ${ }^{210}$ Legal advisor Jay Bybee issued a memo that used the ECHR's case to develop definitions and approved of methods such as sleep deprivation, white noise, stress positions, denying food and water, and hooding. ${ }^{211}$ However, the

positions, threats with dogs, and sleep and sensory deprivation, only to revoke the authorization several weeks later); Leila Nadya Sadat, Ghost Prisoners and Black Sites: Extraordinary Rendition Under International Law, 37 CASE W. RES. J. INT'L L. 309, 340 (2006) (stating that an approach implemented at Guantánamo Bay and Abu Ghraib was to use attack dogs to intimidate inmates); Pearlstein, supra note 138, at 1263-65 (Rumsfeld approved of using attack dogs and other means of generating fears and individual phobias in November 2002); Bejesky, Abu Ghraib Convictions, supra note 19, at 17-31, 60-64 (discussing abuse at Abu Ghraib); Bejesky, Epiphany Approach, supra note 4, at 6-11, 2025 (discussing abuse at Gitmo).

207. U.N. Secretary-General, Torture and Other Cruel, Inhuman or Degrading Treatment or Punishment, $\uparrow \uparrow 77-85$, U.N. Doc. A/63/175 (July 28, 2008).

208. U.S. DEP'T OF STATE, supra note 131, at 107.

209. Paust, supra note 26, at 408-09.

210. Waldron, supra note 97, at 1706; See also International Covenant on Economic, Social and Cultural Rights, art. 11, Dec. 19, 1966, 993 U.N.T.S. 3.

211. Waldron, supra note 97, at 1705-06; Jackson Maogoto \& Benedict Sheehy, Torturing the Rule of Law: USA and the Post 9-11 Legal World, 21 ST. JoHN's J.L. Comm. 689, 721 (2007); Seth F. Kreimer, "Torture Lite," "Full Bodied" Torture, and the Insulation of Legal Conscience, 1 J. NAT'L SECURITY L. \& POL'Y 187, 192 (2005) (noting 
ECHR case involved British interrogators holding Irish detainees for a few days and subjecting them to psychological interrogation methods, ${ }^{212}$ while the Bush Administration's orders routinely subjected hundreds of detainees to more intense interrogation techniques for many months. Nonetheless, shades in the degree of abuse may not have been consequential if the most criticized position of all had been taken seriously.

\section{Nullifying the Relevance of Authorized Interrogation Standards with the Bybee Memo}

Perhaps the most condemned memo, ${ }^{213}$ approved by Bybee but reportedly written by John Yoo in August $2002,{ }^{214}$ imparted a legal defense for government actors carrying out interrogation directives. The Bybee memo stated that for an interrogator to be held criminally responsible for abuse, the interrogator must intend that the victim "experience intense pain and suffering of the kind that is equivalent to the pain that would be associated with serious physical injury so severe that death, organ failure, or permanent damage resulting in a loss of significant bodily function will likely result."215 Alternatively, federal

that another advisory position, provided by Judge Advocate LTC Beaver, acknowledged that the U.S. was restricted from using methods that would be torture or cruel, inhuman and degrading treatment, but maintained that approved interrogation techniques did not violate those restrictions; methods such as sleep deprivation, threatening with dogs, inducing "misperceptions of asphyxiation," and "mind noninjurious contact" did not violate international or domestic law); Charles H. Brower II, The Lives of Animals, the Lives of Prisoners, and the Revelations of Abu Ghraib, 37 VAND. J. TRANSNAT'L L. 1353, 1382 (2004) (interrogators "have used a 110-volt power supply to shock detainees" and "performed 'numerous' simulated asphyxiations to obtain information").

212. Bejesky, Utilitarian Rational Choice, supra note 3, at 405-11.

213. Koh, supra note 69, at 647 (" $[\mathrm{I}] \mathrm{n}$ my professional opinion, the Bybee Opinion is perhaps the most clearly erroneous legal opinion I have ever read."); Waldron, supra note 97, at 1704, 1708 (stating that "[t]he quality of Bybee's legal work here is a disgrace .... [T] hese are obvious errors, and the Department of Justice - as the executive department charged with special responsibility for the integrity of the legal system.").

214. Rachael Ward Saltzman, Executive Power and the Office of Legal Counsel, 28 YALE L. \& POL'Y REV. 439, 440 (2010) (stating that it was later reported that Yoo wrote this memo and Bybee approved it); Barton Gellman \& Jo Becker, Pushing the Envelope on Presidential Power, WASH. POST (June 25, 2007), available at http://blog.washingtonpost.com/cheney/chapters/pushing_the_envelope_on_presi// (last visited Nov. 19, 2013) (explaining that Yoo kept getting "summoned" to the White House to tell CIA officers "what the legal limits of interrogation are" and that administration officials "attributed authorship [of the Bybee memo] to Yoo").

215. Bybee, supra note 54 , at 1,3 (stating that "[w]e conclude by examining possible defenses that would negate any claim that certain interrogations methods violate the statute" and enumerating the high-threshold elements to convict). 
jurisdiction was established over torture crimes and Section 18 U.S.C. $\S$ 2340A absolutely prohibits physical and psychological torture outside the U.S. ${ }^{216}$ The Torture Statute defines torture as "[a]n act committed by a person acting under the color of law specifically intended to inflict severe physical or mental pain or suffering."217

The Bybee memo's position that such a malicious mens rea is required for a high-level abuse is particularly surprising when federal courts have interpreted that specific intent for torture can also exist when there is an intentional act that leads to "prolonged mental pain or suffering" that is a foreseeable consequence of the deliberate act. ${ }^{218}$ Moreover, the Torture Statute is a generally-applicable law that does not mention interrogation, but interrogation itself involves a governmentsanctioned level of dominance by the interrogator over the captive and the relationship is specifically anticipated to employ specific acts to inflict harm and make the subject obliging.

With the Bybee memo's excessively high standard for culpability, a government's logical retort to criticism could be that chain of command directives could not have authorized illegal orders because authorized psychological interrogation tactics were limited and interrogators were not convicted of crimes. ${ }^{219}$ After all, the legal advice

216. 18 U.S.C. $\S 2340 \mathrm{~A}, 2340$ (1) (2012). There are emerging trends in transnational plaintiff litigation. Harold Hongju Koh, Transnational Public Law Litigation, 100 YALE L.J. 2347 (1991); Anne-Marie Slaughter \& David Bosco, Plaintiffs Diplomacy, 2002 For. AFFAIRS 102 (2000).

217. 18 U.S.C. $§ 2340$ (2012) (“[S]evere mental pain or suffering" defined as "prolonged mental harm caused by or resulting from... the intentional infliction or threatened infliction of severe physical pain or suffering; the administration or application, or threatened administration or application, of mind-altering substances or other procedures calculated to disrupt profoundly the senses or the personality; the threat of imminent death; or the threat that another person will imminently be subjected to death, severe physical pain or suffering, or the administration or application or mind-altering substances ...").

218. Habtemicael v. Ashcroft, 370 F.3d 774, 782 (8th Cir. 2004); Zubeda v. Ashcroft, 333 F.3d 463, 473 (3d Cir. 2003); see Garcia, supra note 189, at 2 ("[A]n act that results in unanticipated and unintended severity of pain and suffering is not torture for purposes of the Convention.").

219. Daniel Levin, Legal Standards Applicable Under 18 U.S.C. $\$ \$ 2340-2340$ A, U.S. DEP'T OF JUSTICE (Dec. 30, 2004), available at http://www.justice.gov/olc/18usc23402340a2.htm (last visited Nov. 19, 2013) (Memo withdrawing the legal advice on liability and noting that discussion on liability was unnecessary because "[c]onsideration of the bounds of any such authority would be inconsistent with the President's unequivocal directive that United States personnel not engage in torture."); John T. Parry, "Just for Fun": Understanding Torture and Understanding Abu Ghraib, 1 J. NAT'L SECURITY L. \& POL'Y 253, 267 (2005) ("If the Torture Convention is the controlling document, then a state that wishes to justify its violence need only assert that, whatever it may have done, it has not tortured. At this point the discussion gets bogged down in definitions."); Senate Judiciary Committee Grills 
states that to be illegal, torture must "inflict pain that is difficult to endure," such as pain similar to "death or organ failure," as distinguished from cruel and inhuman acts. ${ }^{220}$ Most significant to the approved interrogation methods is that "[m]ental torture" must cause "significant psychological harm of significant duration, e.g., lasting for months or even years," 221 which would surely be arduous for a detaineeplaintiff or prosecutor to prove.

With a substantial gap between definitions prohibiting torture under U.S. and international law and the punishment standards contained in the Bybee memo, interrogators may have believed that their own acts would not be criminally culpable irrespective of the Administration's authorized techniques. ${ }^{222}$ The high threshold criterion might also have been further promoted because the Bybee memo reiterated that even if there were violations of the U.S. Code, the Commander in Chief could still use "flexible" means of interrogation to attain information that would prevent terrorist attacks, pursuant to "necessity" and "self-defense" justifications. ${ }^{223}$

Approved interrogation methods and the President's direction for interrogation to remain within U.S. law do not explain how so many captives kept emerging with indications that they were severely beaten or how as many as two hundred detainees died, with at least 34 confirmed homicides while in U.S. custody between August 2002 and $2006 .{ }^{224}$ In Afghanistan and Iraq, U.S. military doctors signed many

Ashcroft on Justice Dept. Memo, PBS (June 8, 2004), available at http://www.pbs.org/newshour/bb/government_programs/jan-june04/torture_6-8.html (last visited Nov. 19, 2013) (In responding to the scandal following the Abu Ghraib atrocities, Rumsfeld remarked: "Let me completely reject the notion that anything that this President has done or the Justice Department has done has directly resulted in the kind of atrocity which were cited. . .There is no Presidential order immunizing torture.").

220. Bybee, supra note 54, at 1 .

221. Id. at 7 .

222. For example, the Bush Administration's interrogation standards did not approve of organ failure and death as pressure tactics to gain information, but the same agency of government - the Justice Department - is the same agency that is empowered to decide whether to criminally prosecute. Scott Shane, David Johnston \& James Risen, Secret U.S. Endorsement of Severe Interrogations, NY TIMES (Oct. 4, 2007), available at http://www.nytimes.com/2007/10/04/washington/04interrogate.html?pagewanted=all\&_r=0 (last visited Nov. 19, 2013).

223. Bybee, supra note 54, at 31, 39-45.

224. Command's Responsibility: Detainee Deaths in U.S. Custody in Iraq and Afghanistan, HUM. RTS. FIRST (Feb. 1, 2006), available at http://www.humanrightsfirst.org/wp-content/uploads/pdf/06221-etn-hrf-dic-rep-web.pdf (last visited Nov. 19, 2013); Bassiouni, supra note 16, at 390, 398-99, 406 (placing the death toll caused by interrogation practices at 200 detainees through 2006); Stephen N. Xenakis, More on: “Doctors Must Be Healers", 37 Seton Hall L. ReV. 703, 706 (2007) (at 
detainee death certificates with causes that were tantamount to torture, ${ }^{225}$ but interrogators were not being prosecuted ${ }^{226}$ even though torture and acts of cruel and unusual punishment require punishment under international law. ${ }^{27}$ Is it possible that legal advice regarding the mens rea of interrogators undermined the reasonable application of approved interrogation standards and that the legal advice was incompatible with the definition of a criminally punishable act under international and domestic law?

Given the definition in U.S. federal law, many scholars and government and military lawyers expressed that the memo mangled the definitions of torture and culpability for torture, ${ }^{228}$ provided a "breathtakingly expansive view of presidential powers," was inconsistent with jus cogens norms, ${ }^{229}$ and endorsed criminal conduct. ${ }^{230}$

least 98 detainees died in U.S. custody, and Physicians for Human Rights tallied 105 deaths in Iraq and Afghanistan between 2002 and 2005); James W. Smith III, A Few Good Scapegoats: The Abu Ghrabi Courts-Martial and the Failure of the Military Justice System, 27 WhitTIER L. REV. 671, 675 (2006) (noting that the British also engaged in torture of detainees that resulted in deaths); Report: 108 Die in U.S. Custody, CBS News (Mar. 16, 2005), available at http://www.cbsnews.com/stories/2005/03/16/terror/main680658.shtml (last visited Nov. 19, 2013) (noting that based on information supplied by the Army, Navy and other government agencies, at least 108 detainees died in U.S. custody).

225. Bassiouni, supra note 16 , at $402-03,406$.

226. Khan, supra note 20 , at 8 (stating that despite this evidence of deaths during interrogation, "not one single CIA personnel has been prosecuted"). By comparison, in the rare case of prosecution during the Vietnam War, the military court held that "whether Lieutenant Calley was the most ignorant person in the United States Army in Vietnam or the most intelligent, he must be presumed to know that he could not kill the people involved here." U.S. v. Calley, 22 U.S.C.M.A. 534, 544 (C.M.A. 1973).

227. Bejesky, Pruning, supra note 4, at 829-36.

228. Michael L. Kramer \& Michael N. Schmitt, Lawyers on Horseback? Thoughts on Judge Advocates and Civil-Military Relations, 55 UCLA L. REv. 1407, 1418 (2008).

229. David A. Wallace, Torture v. The Basic Principles of the U.S. Military, J. INT'L CRIM. JUST. (May 2008), available at http://jicj.oxfordjournals.org/content/6/2/309.full.pdf (last visited Nov. 19, 2013); Association of the Bar of the City of New York Committee on Federal Courts, The Indefinite Detention of "Enemy Combatants": Balancing Due Process and National Security in the Context of the War on Terror, RECORD (2004), available at http://www.nycbar.org/pdf/1C_WL06!.pdf (last visited Nov. 19, 2013) (noting the "almost unlimited expansion of executive power" specifically because "the domestic war on terror" was treated as the same as " "total war' circumstances of World War II and the Civil War"); IN THE NAME OF DEMOCRACY, supra note 17, at 105 (former Nixon Counsel John Dean stating that the Bybee "Torture Memo" is "damning evidence suggesting a common plan [or conspiracy] on the part of the Administration to violate the laws of war"); Jordan J. Paust, Civil Liability of Bush, Cheney, et al. for Torture, Cruel, Inhuman, and Degrading Treatment and Forced Disappearance, 42 CASE W. RES. J. INT'L L. 359, 361 (2009) ("[M]emoranda ... facilitated the common, unifying plan devised by an inner circle to use torture."). If Dean is correct, the memo could implicate top officials as conspirators in deaths and abuse that resulted after the order's issuance date. Id.; United States v. Laster, 42 
Explaining precisely what transpired, Professor Mary Ellen O'Connell explains that the authors of the memo ignored "the negotiating history of the treaty" and "went to a completely unrelated document, a health care statute, found a provision that they liked, and from this statute they constructed a definition of torture that limited torture to actions inflicting the pain of 'organ failure or death.",231

Even John Yoo conceded that the memorandum does not represent "majority views among international law academics," 232 but a former White House lawyer believed the memo's perspective was more strained than a minority opinion and estimated that "if you line up 1,000 law professors, only six or seven would sign up to [the torture memo's viewpoint]." ${ }^{233}$ In a June 2004 press conference, Gonzales contended that there were "unnecessary, over-broad discussions in some of these memos that address abstract legal theories, or discussions subject to misinterpretation, but [those opinions were] not relied upon by decisionmakers are under review, and may be replaced, if appropriate, with more concrete guidance." ${ }^{234}$ If this is true and the torture memo was a

M.J. 538, 540 (A.F. Ct. Crim. App. 1995) (noting that under military law, circumstantial evidence can provide the basis to infer that there was an agreement to commit a crime between two parties).

230. Wallace, supra note 229 , at 313 (calling the string of memos "overly legalistic and patently erroneous attempts to redefine torture"); Peter Brooks, The Plain Meaning of Torture?, SLATE (Feb. 9, 2005), available at http://www.slate.com/articles/news_and_politics/jurisprudence/2005/02/the_plain_meaning _of_torture.html (last visited Nov. 19, 2013) (calling the opinion "the work of some bizarre literary deconstructionist"); Anthony Lewis, Making Torture Legal, N.Y. REV. BooKs (July 15, 2004), available at http://www.nybooks.com/articles/17230 (last visited Nov. 19, 2013) (stating that the memo is equivalent to "the advice of a mob lawyer to a mafia don on how to skirt the law and stay out of prison").

231. O'Connell, Responses, supra note 5, at 5136.

232. R. Jeffrey Smith, Slim Legal Grounds for Torture Memorandums, WASH. PoST, Aug. 5, 2004, at A4 (quoting John Yoo).

233. John Hagan, Gabrielle Ferrales \& Guillermina Jasso, How Law Rules: Torture, Terror, and the Normative Judgments of Iraqi Judges, 42 LAW \& Soc'Y REV. 605, 610 (2008); M. Cathleen Kaveny, Donald A. Giannella Memorial Lecture: Prophecy and Casuistry: Abortion, Torture and Moral Discourse, 51 VILL. L. REv. 499, 530 (2006) (noting that a percentage of Catholics repudiated Bush for using specious reasons to wage war against Iraq and that revelations of torture and memos justifying torture called into question Bush's commitment to human dignity).

234. Press Briefing by White House Counsel Alberto Gonzales, et al., WHITE HouSE (Sept. 25, 2004), available at http://georgewbushwhitehouse.archives.gov/news/releases/2004/06/20040622-14.html (last visited Nov. 19, 2013); Edward Alden, Top Lawyers Call Legal OK for Torture 'Preposterous', FIN. TIMES (Sept. 25, 2004), available at http://archive.truthout.org/article/top-lawyers-call-legal-oktorture-preposterous (last visited Nov. 19, 2013) (stating that Yoo referred to the opinion as "an abstract analysis of the meaning of a treaty and a statute."). 
response to a policymaker request, it makes one wonder how many of the other advisory memos were intended to be planks of initial cogitation.

Perhaps it was partially the glut of warnings of abuse ${ }^{235}$ and appalling victim accounts that puzzled Senators when Gonzales testified before the Senate in January 2005 and when he explained emphatically that the Bybee memo had been withdrawn and that he and Bush had both repudiated torture. ${ }^{236}$ Senator Kennedy retorted by remarking that "for a two-year period when it was in effect, you didn't object to it.",237 In fact, it took until June 2005 for the U.S. government to even admit that prisoners had been subjected to abuse amounting to torture in Guantánamo Bay, Iraq and Afghanistan. ${ }^{238}$.By this point, the Bush Administration had already renamed the interrogation approaches and tweaked the standards.

\section{Modifying the Bybee Memo and Using "Enhanced Interrogation"}

In December 2004, Assistant Attorney General Daniel Levin, wrote a memo that withdrew the language of the Bybee memo, written over two years earlier, that required pain equivalent to "organ failure, impairment of bodily functions, or even death." 239 The new memo stated that to meet the definition of punishable torture, physical harm must be severe in "intensity and duration or persistence" and more than "mild and transitory pain," and that "mental harm must be of some lasting duration," but the harm need not last for "months or years.",240

235. Bejesky, Abu Ghraib Convictions, supra note 19, at 19-22 (explaining that the Bush Administration had been warned about illegalities in American prison facilities long before the memo was reportedly rejected).

236. Senate Judiciary Committee Confirmation Hearing, N.Y. TIMES (Sept. 25, 2005), available at http://www.nytimes.com/2005/01/06/politics/06TEXTGONZALES.html?_r=0\&pagewanted=all\&position $=($ last visited Nov. 19, 2013) $($ Gonzales stating, after being questioned over whether he agreed with the interpretation of the standard for torture in the Bybee memo, "I do not [agree with that interpretation]. That does not represent the position of the executive branch.").

237. Id.

238. US Acknowledges Torture at Guantánamo; in Iraq, Afghanistan - UN, AFX NEwS LIMITED (Sept. 25, 2005), available at http://web.archive.org/web/20060207165836/http://www.forbes.com/work/feeds/afx/2005/0 6/24/afx21 10388.html (last visited Oct. 2, 2013) (UN Committee member stating: "They are no longer trying to duck this and have respected their obligation to inform the UN.").

239. Levin, supra note 219.

240. Id. (calling the torture memo "abhorrent both to American law and values and to international norms" and that there may be questions of whether an interrogator "specifically intended" to engage in an act of torture "in light of the President's directive 
Citing a Supreme Court case to address interrogator culpability, the revised OLC memo stated that if an interrogator "acted in good faith, and only after reasonable investigation establishing that his conduct would not inflict severe physical or mental pain or suffering, it appears unlikely that he would have the specific intent necessary of violate sections 2340-2340A."241

Professor Jack Goldsmith replaced Bybee as head of the OLC in 2003 and rescinded many of the opinions ${ }^{242}$ and called Yoo's work from 2001 to 2003 "deeply flawed: sloppily reasoned, overbroad, and incautious in asserting extraordinary constitutional authorities on behalf of the President." 243 Goldsmith was "anointed as a hero by the media" for repealing the memos, ${ }^{244}$ but Goldsmith had also been known to represent an ideological position that preferred to treat international law as discretionary norms, ${ }^{245}$ and his 2004 OLC memo added a footnote stating that "all the interrogation methods that earlier opinions had found legal were still legal."246 The footnote arguably nullified the relevance of the new memo and John Yoo apparently believed that Goldsmith's withdrawal of the opinion was merely "'for appearances' sake to divert public criticism in the immediate aftermath of the Abu Ghraib controversy. "In the real world of interrogation policy nothing had changed.",247

that the United States not engage in torture").

241. Id.

242. Saltzman, supra note 214, at 446.

243. Dan Eggen \& Peter Baker, New Book Details Cheney Lawyer's Efforts to Expand Executive Power, WASH. POST (Sept. 5, 2007), available at http://www.washingtonpost.com/wp-

dyn/content/article/2007/09/04/AR2007090402292.html (last visited Nov. 19, 2012); JACK Goldsmith, The Terror Presidency: LAW and Judgment Inside the Bush Administration 146-50 (W.W. Norton \& Company 2007); Yamamoto, supra note 66, at 318-19 (citing lists of other legal authorities).

244. Scharf, supra note 17, at 349.

245. Margaret E. McGuinness, Exploring the Limits of International Human Rights Law, 34 GA. J. INT'L \& COMP. L. 393, 421 (2006) (critiquing Posner and Goldsmith's realist ideological book and stating that " $[\mathrm{t}]$ he book cannot be viewed as separate from the authors' broader normative project - a project that seeks to minimize U.S. participation in U.S. institutions and to limit the application of the international law," and noting Goldsmith's realist ideological affinity with other advisors).

246. Scharf, supra note 17, at 349 (citing Yoo, supra note 38, at 183); GolDSMITH, supra note 243, at 155-56; Power, supra note 15, at 97-98 (stating that Goldsmith was entirely supportive of the Bush Administration, but partially cleaned the mess left by anteceding memos).

247. Scharf, supra note 17, at 349 (citing Yoo, supra note 38, at 183). 
It does appear that nothing had changed. In February 2005, shortly after Alberto Gonzales became Attorney General and about one month after Levin's memo was produced, Gonzales endorsed methods that were reportedly "the harshest interrogation techniques ever used by the Central Intelligence Agency." 248 Other than waterboarding, the new methods that authorized degrees of physical touching could probably already be presumed to be occurring and many methods were the same as or substantially similar to the techniques approved in 2002, but they were now labeled "Enhanced Interrogation Techniques." 449 Only the label was changed on methods that were already called torture. ${ }^{250}$ For example, JAG attorneys, the international community, and U.S. courts have called waterboarding torture, ${ }^{251}$ but CIA Director Porter Goss

248. Shane, Johnston \& Risen, supra note 222; R. Jeffrey Smith \& Dan Eggen, Gonzales Helped Set the Course for Detainees, WASH. Post (Jan. 5, 2005), available at http://www.washingtonpost.com/wp-dyn/articles/A48446-2005Jan4.html (last visited Nov. 19,2013 ) (noting that Gonzales had intricate involvement because he chaired meetings with top government officials that detailed "how much pain and suffering a US intelligence officer could inflict on a prisoner without violating" U.S. criminal law and that approved methods included "“waterboarding,' a tactic intended to make detainees feel as if they are drowning" and the "threat of live burial").

249. These "Enhanced Interrogation Techniques" included grabbing and slapping prisoners, shaking them to get their attention, imposing long-time standing, placing detainees in "cold cells," and using "waterboarding." Brian Ross \& Richard Esposito, CIA's Harsh Interrogation Techniques Described, ABC NEws (Nov. 18, 2005), available at http://abcnews.go.com/Blotter/Investigation/story?id=1322866 (last visited Nov. 19, 2013); See supra Parts III(F)(3)(4).

250. Resnick, supra note 10 , at 614 (explaining that "[t]he labels 'enhanced interrogation,' 'harsh' techniques, and 'coercion' have been offered up in lieu of the words torture, and the cruel, inhuman, and degrading treatment" to define detainment conditions); Bassiouni, supra note 16, at 393 (calling the memos "permissible interrogation techniques" was just "a euphemism for torture"); Manfred Nowak, Moritz Birk \& Tiphanie Crittin, The Obama Administration and Obligations Under the Convention Against Torture, 20 TRANSNAT'L L. \& CONTEMP. ProBS. 33, 34 (2011) (noting that the memos were ostensibly endeavoring to further justify the system of extraordinary rendition flights and secret CIA detention facilities).

251. Scott Horton, The JAGs Set the Record Straight, HARPER's (Nov. 4, 2007), available at http://harpers.org/archive/2007/11/hbc-90001588 (last visited Nov. 19, 2013) (noting that JAG attorneys "unanimously and unambiguously agreed that [waterboarding is] inhumane and illegal and would constitute a violation of international law, to include Common Article 3 of the 1949 Geneva Conventions."); Martin Hodgson, US Censored for Waterboarding, THE GUARDIAN (Feb. 6, 2008), available at http://www.guardian.co.uk/world/2008/feb/07/humanrights.usa (last visited Nov. 19, 2013) (UN Special Rapporteur on Torture, Manfred Nowak remarking, "I'm not willing any more to discuss these questions with the U.S. government, when they say [waterboarding] is allowed. It's not allowed."). After World War II, the U.S. prosecuted Japanese officials for using waterboarding and U.S. courts have customarily classified waterboarding as a form of torture. Power, supra note 15, at 85; Evan Wallach, Drop by Drop: Forgetting the History of Water Torture in U.S. Courts, 45 Colum. J. TranSNAT'L L. 468, $472-99$ (2007); Jordan J. 
explained that waterboarding is "an area of what I call professional interrogation techniques." ${ }^{252}$ Against the order of Congress, the CIA destroyed the interrogation tapes of detainees who were subject to waterboarding. ${ }^{253}$

Even after all of the criticism and challenges to the standards, methods approved, and culpability level for interrogation, the President continued to pronounce discretion under the Commander in Chief power ${ }^{254}$ and contended that the CIA had authority to choose interrogation methods. $^{255}$ In summer 2007, the Justice Department issued "letters," instead of "advisory memos," and noted that the Bush Administration was retaining flexibility in permitting the CIA's "harsher interrogation techniques." 256 Instead of addressing torture and

Paust, The Absolute Prohibition of Torture and Necessary and Appropriate Sanctions, 43 VAL. U. L. REV. 1535, 1553 (2009) (water-boarding "manifestly and unavoidably constitute[s] torture").

252. Douglas Jehl, Questions Left by C.I.A. Chief on Torture Use, N.Y. TimES (Mar. 18, 2005), available at http://www.nytimes.com/2009/04/20/world/20detain.html (last visited Nov. 19, 2013) (noting that the CIA subjected Khalid Shaikh Mohammed and Abu Zubaydah to waterboarding for a combined total of 266 sessions); Dan Eggen, Justice Official Defends Rough CIA Interrogations: Severe, Lasting Pain is Torture, He Says, WASH. POST, Feb. 17, 2008, at A3 (reporting that OLC advisor Steven G. Bradbury explained to a House subcommittee that "if it doesn't involve severe physical pain, and it doesn't last very long, it may not constitute severe physical suffering" and noting that waterboarding is not torture). Republican candidate Rudy Giuliani stated that whether waterboarding is legal "depends on how it's done. It depends on the circumstances. It depends on who does it." Michael Cooper, In His Words: Giuliani on Torture, N.Y. TIMES (Oct. 25, 2007), available at http://thecaucus.blogs.nytimes.com/2007/10/25/in-his-ownwords-giuliani-on-torture/ (last visited Nov. 19, 2013).

253. Scott Shane, Prosecutor to Review Official Handling of C.I.A. Tapes, N.Y. TIMES (Feb. 10, 2008), available at http://www.nytimes.com/2008/02/10/us/10tapes.html?_r $=0$ (last visited Nov. 19, 2013).

254. Charlie Savage, Bush Could Bypass New Torture Ban, Boston GloBe (Jan. 4, 2006), available

at http://www.boston.com/news/nation/articles/2006/01/04/bush_could_bypass_new_torture_b an/?page=full (last visited Nov. 19, 2013) (reporting that after Congress passed the Detainee Treatment Act (DTA) to prohibit torture of detainees, Bush included a "signing statement," asserting that he had the prerogative to bypass the law as commander in chief). The signing statement should have no legal effect because Congress defines the expanse of the Commander in Chief authority. Bejesky, War Powers, supra note 32, at 28-33, 89-93.

255. Exec. Order No. 13440 (July 20, 2007), available at http://www.fas.org/irp/offdocs/eo/eo-13440.htm (last visited Nov. 19, 2013) (reaffirming that the Geneva Convention did not apply to "al-Qaeda, the Taliban, and associated forces" and that the CIA was authorized to engage in "certain detention and interrogations" that are not torture or cruel and inhumane treatment, with the "conditions of confinement and interrogation practices" determined by the CIA).

256. Mark Mazzetti, Letters Give C.I.A. Tactics a Legal Rationale, N.Y. TIMEs (Apr. 27, 2008), available at http://www.nytimes.com/2008/04/27/washington/27intel.html (last visited Nov. 19, 2013). 
cruel and inhumane treatment, the "letter" distracted attention onto a new and lesser category of offense by noting that there would be no violation of the Geneva Convention's prohibitions of "outrages upon personal dignity" as long as interrogation procedures did not intend to humiliate, there was a need to defend the U.S., or if the act of humiliation was not "so deplorable that the reasonable observer would recognize it as something that should be universally condemned."257

In a peculiar interpretation of what transpired, Goldsmith wrote in his book that the Bush Administration experienced a failed attempt at presidential expansionism, was "strangled by law," and did not sufficiently rely on "soft power" persuasion to attain consent for its policies. ${ }^{258}$ The Bush Administration did not appear to be "strangled by law" to implement interrogation initiatives because as new human rights abuses were reported, new standards were devised, time passed, and more loopholes opened based on discretionary circumstances and actions hidden in national security secrecy.

With respect to laws that prohibit wars of aggression and the use of rhetoric to persuade, Bush readily issued unsubstantiated terror threat announcements to the American public to drive fear rhetoric ${ }^{259}$ and top Bush Administration officials made at least 935 patently false statements and hundreds of other misleading statements on 532 different occasions about weapons of mass destruction and ties to al-Qaeda to persuade Americans that Iraq was a security threat and needed to be invaded. ${ }^{260}$ Nobel Laureate Joseph Stiglitz and Harvard Professor Linda Bilmes estimated that the war in Iraq cost the American public upwards of \$3 trillion when including indirect expenditures, and Bush departed from office with the lowest recorded American Presidential approval ratings in history at $22 \%$, which was due to the Iraq war and poor economic conditions. ${ }^{261}$ Not being restrained by law and implementing persuasive tactics without consequence were substantially due to misuse of the secrecy prerogatives of the national security apparatus.

257. Id.

258. GoLDSMITH, supra note 243 , at $69,205-16$.

259. Bejesky, Rational Choice Reflection, supra note 3, at 37-48; Bejesky, CFP, supra note 110 , at $20-24$.

260. Robert Bejesky, Press Clause Aspirations and the Iraq War, 48 WillameTte L. REV. 343, 348-49 (2012).

261. Robert Bejesky, Political Penumbras of Taxes and War Powers for the 2012 Election, 14 Loy. J. PuB. INT. L. 1, 1-3 (2012). 


\section{A POLITICIZED ROLE WITH SECRECY}

\section{A. The Secrecy Pipeline}

As public revelations of human rights abuses and public excoriation periodically emerged, generally from whistleblower accounts or investigations, the Bush Administration delayed thorough investigations by unilaterally choosing to hide legal advice under national security by designating legal advice, orders for interrogation, and execution of directives as pieces of encompassing covert operation; ${ }^{262}$ diluted responsibility by timely declassifying memos to defend that previously issued interrogation directives were legal; and then modified standards and definitions so they could continue virtually the same operations. The Geneva Conventions and criminal law prohibitions against torture and interrogation were unilaterally dismissed with classified legal advice ${ }^{263}$ and successions of wrongs passed without accountability being imposed and with the Bush Administration only experiencing minimal and temporary political fallout.

It is true that the lawyers in the Attorney General's Office can have multiple roles because they must enforce the law and defend the U.S. government when there is a case or controversy, but the zealous

262. Anthony Arnove, IraQ: The Logic of Withdrawal, 24 (News Press, $1^{\text {st }}$ ed. 2006) (stating that the Justice Department memos and Presidential orders authorized obscene powers to intelligence and military agents to detain and interrogation and that memos were eventually declassified); Pearlstein, supra note 138, at 1273 (stating that "Congress was largely absent from engagement in U.S. policies of detention and interrogation from 2001 through much of 2005."); Transcript: Reps. Harman, Hoekstra on 'FNS', FoX NEwS (Dec. 16, 2007), available at http://www.foxnews.com/story/2007/12/16/transcript-reps-harman-hoekstra-on-fns/ (last visited Nov. 19, 2013) (Congresswoman Jane Harman noting: "We have a system of checks and balances and it's broken. We're in Constitutional crisis because of the arrogant view of some in this administration that they can decide what the policy is, write the legal opinions to justify that policy and be accountable to no one."). The use of Extraordinary Rendition provides a good example. Kreimer, supra note 31, at 1189-90; Louis Henkin, A Decent Respect to the Opinions of Mankind, 25 JOHN MARShall L. Rev. 215, 231 (1992) ("abducting a person from a foreign country is a gross violation of international law and ... the territorial integrity of another state"); Lila Rajiva, The CIA 's Rendition Flights to Secret Prisons: The Torture-Go-Round, COUNTERPUNCH (Dec. 5, 2005), available at http://www.counterpunch.org/rajiva12052005.html (last visited Nov. 19, 2013) (stating that there was significant evidence supporting a "long line of renditions without cause/due process of any kind" and that the Bush Administration was falsely representing that nothing illegal was occurring).

263. John J. Gibbons, Commentary on the Terror on Trial Symposium, 28 REv. Litig. 297, 300-01 (2008). 
advocate is not the proper role for legal advisors who provide consultation for policy development. Recall that the White House specifically requested advisors to provide ways to "exercise the full panoply of powers granted the president by Congress and the Constitution" and stated that he did not care if that meant "pushing the boundaries of the law." ${ }^{264}$ Advisors did push the boundaries of the law and commentators have called the legal advice despicable, professionally unethical, ${ }^{265}$ in violation of non-derogative international law, ${ }^{266}$ and even criminal. ${ }^{267}$ Condemnations followed after policies were executed due to the use of the national security apparatus.

264. Thomas, supra note 11; Neil M. Peretz, The Limits of Outsourcing: Ethnical Responsibilities of Federal Government Attorneys Advising Executive Branch Officials, 6 ConN. PuB. INT. L. J. 23, 23-24 (2006) (stating that there is the possibility that legal advisors could issue opinions to curry favor with bosses).

265. Waldron, supra note 97, at 1687 (emphasizing that it is unfortunate that "views and proposals like these should be voiced by scholars who have devoted their lives to the law, to the study of the rule of law, and to the education of future generations of lawyers is a matter of dishonor for our profession"); Saltzman, supra note 214, at 440-41 (reporting that after the change in Administration, the Justice Department's Office of Professional Responsibility and other authorities recommended that the authors of the memos should be referred to proper disciplinary authorities); Power, supra note 15, at 41 ("Law drove policy decisions throughout the war, and not always in good or morally justifiable ways.").

266. Bejesky, Utilitarian Rational Choice, supra note 3, at 386-92 (discussing how advisory memos were inconsistent with prohibitions on torture); Jesselyn Radack, Tortured Legal Ethics: The Role of the Government Advisor in the War on Terrorism, 77 COLO. L. REV. 1, 24 (2006) ("The acts endorsed by the torture memoranda violate a jus cogens norm of international law by advocating and excusing acts of torture."); Waldron, supra note 97, at 1681 (noting that the torture memoranda subvert the rule of law); Paust, supra note 5, at 861-62 ("As various memoranda, authorizations and actions noted above demonstrate, there were plans to deny protections under the Geneva Conventions... The plans to deny protections ... violate the [Geneva] Conventions, and violations of the Conventions are war crimes.").

267. Koh, supra note 69 , at 654 ("if a client asks a lawyer how to break the law and escape liability, a good lawyer should not say, 'here's how.' The lawyer's ethical duty is to say no."); Milan Markovic, Can Lawyers Be War Criminals?, 20 Geo. J. LeGAL ETHICs 347, $349,357,362-63$ (2007) ("lawyers are potentially complicit in war crimes when they 'materially contribute' to the commission of crimes like torture," including via the International Criminal Court or under the Convention Against Torture); Scott Higham, Law Experts Condemn U.S. Memos on Torture, WASH. Post (Aug. 5, 2004), available at http://www.washingtonpost.com/wp-dyn/articles/A41 189-2004Aug4.html (last visited Nov. 19, 2013) (quoting John J. Gibbons, former Chief Judge of the Third Circuit Court of Appeals) ("The position taken by the government lawyers [within the Bush Administration] in these legal memoranda amount to counseling a client as to how to get away with violating a law."). 


\section{B. Using Secrecy to Hide Illegal Orders}

One of the first of the later condemned directives was issued shortly after $9 / 11$ by Secretary of Defense Rumsfeld, who launched a "special-access program" to assassinate or capture and interrogate "high value targets."268 International law prohibits assassinations and an executive order has long banned American government officials from ordering assassinations, but Bush explained that he was not waiving the executive order, but instead killing "enemy combatants." ${ }^{269}$ The Bush Administration tasked the CIA with abducting suspected terrorists and conducting hundreds of covert flights across the world to deliver prisoners to secret detention centers and other countries with Extraordinary Rendition. ${ }^{270}$ Secret prisons prima facie violate the Geneva Conventions and International Committee of the Red Cross inspection requirements, ${ }^{271}$ but Bush did not officially acknowledge the secret detention centers until September $2006 .{ }^{272}$ International law forbids abductions and rendering individuals to countries when it is

268. Seymour M. Hersh, The Gray Zone: How a Secret Pentagon Program Came to Abu Ghraib, THE NEW YORKER (May 24, 2004), available at http://www.newyorker.com/archive/2004/05/24/040524fa_fact?currentPage=all (last visited Nov. 19, 2013); Seymour M. Hersh, Rumsfeld's Dirty War on Terror, GuARDIAN HouSE (Sept. 13, 2004), available at http://www.informationclearinghouse.info/article6898.htm (last visited Nov. 19, 2013) (describing abductions and noting that they had been occurring from 2001 to 2004). Secrecy was manifest because the only individuals privy to the operations were a few top Bush Administration officials and about two hundred Navy SEALs and Army Delta Force who were to execute operations in elite squads. Noted in MCCoy, supra note 49, at 116-17; Adeno Addis, The "War on Terror" as an Autoimmunity Crisis, 87 B.U. L. REV. 323, 339 (2007); GREG Grandin, EMPIRE's WorKSHOP 88 (Metro. Books, 2006) (stating that there were reports of the U.S. aiding paramilitary groups "accused of assassinations and torture" and that a former high-level intelligence agent explained that locals were being recruited in the same way that the Reagan Administration founded and financed "right-wing execution squads in El Salvador").

269. James Risen \& David Johnston, Threats and Responses: Hunt for al Qaeda; Bush has Widened Authority of C.I.A. to Kill Terrorists, N.Y. TIMES (Dec. 15, 2002), available at http://www.nytimes.com/2002/12/15/world/threats-responses-hunt-for-al-qaeda-bush-haswidened-authority-cia-kill.html (last visited Nov. 19, 2013); Brian Whitaker \& Oliver Burkeman, Killing Probes the Frontiers of Robotics and Legality, GuARDIAN (Nov. 6, 2002), available at http://www.guardian.co.uk/world/2002/nov/06/usa.alqaida (last visited Nov. 19, 2013) (reporting that Anna Lindh, the Swedish foreign minister, called such assassinations "a summary execution that violates human rights").

270. MCCoY, supra note 49, at 116-17; Bejesky, Sensibly Construing, supra note 135, at $1-3,6-10$.

271. Geneva Protocol Additional, supra note 27, art. 75; Symposium, Left Out in the Cold? The Chilling of Speech, Association, and the Press in Post-9/11 America, 57 AM. U. L. REv. 1203, 1203 (2008); Louis Fisher, Extraordinary Rendition: The Price of Secrecy, 57 AM. U. L. REV. 1405, 1450 (2008).

272. Khan, supra note 20 , at 6-7. 
expected that the detainee will be tortured, and Congress must approve of rendition programs. ${ }^{273}$ Orders to engage in abusive interrogations began secretly and from the beginning, it seemed that the assumption was that lawmakers and the public had no right to know. ${ }^{274}$

CIA Director Tenet reportedly went to the White House to attain approval to permit minute details of interrogation to protect agents from criminal prosecution ${ }^{275}$ and Bush purportedly exempted the CIA from military rules on interrogation after $9 / 11$ under the rationale that "certain terrorists might have information that might save American lives" and even noted that criminal law restrictions could be avoided in specific circumstances. ${ }^{276}$ The problem with the requests and assumed legitimacy of exemptions is that the President does not have the authority to grant another government agency the right to violate criminal law or human rights law, particularly if methods approved rise to the level of torture or a jus cogens violation, or the right to exempt an agency from international laws that are binding inside a war zone, ${ }^{277}$ which is also unrelated to protecting American civilians from terrorist attacks.

After operations were executed, secrecy undermined criminal justice processes in the two high-profile and rare prosecutions. In 2006, CIA contract employee David A. Passaro was convicted of assault for the death of Afghan detainee Abdul Wali in June $2003 .^{278}$ At the beginning of the trial, Passaro sought to introduce classified memos and emails and to subpoena CIA officials to prove that CIA superiors directed and approved of abusive practices, but the judge denied his

273. Bejesky, Sensibly Construing, supra note 135, at 10-12.

274. ARNOVE, supra note 262 , at 26 (testifying before a joint House and Senate intelligence committee hearing, Cofer Black, the head of the CIA's Counterterrorism Center, claimed that "operational flexibility" was needed in dealing with suspected terrorists and stated: "This is a very highly classified area, but I have to say that all you need to know: There was a before $9 / 11$, and there was an after $9 / 11$. . After $9 / 11$ the gloves come off."); CIA Interrogation Techniques: What Did Congress Know, CNN, (Dec. 13, 2007), available at http://transcripts.cnn.com/TRANSCRIPTS/0712/13/ltm.02.html (last visited on Nov. 19, 2013) (stating that sometime in 2002, four Congresspersons on the SSCI were the first to be informed that the CIA would be engaging in an operation involving harsh interrogation methods to attain information from captives).

275. Alan Clarke, Creating a Torture Culture, 32 Suffolk Transnat'L L. Rev. 1, 45 (2008).

276. Senate Judiciary Committee, supra note 236.

277. Bejesky, Pruning, supra note 4, at 829-36; See supra Part II.

278. Gregory P. Bailey, Note, United States v. Passaro: Exercising Extraterritorial Jurisdiction Over Non-Defense Department Government Contractors Committing Crimes Overseas Under the Special Maritime and Territorial Jurisdiction of the United States, 58 CATH. U. L. REV. 1143, 1157-59 (2009). 
request in a closed hearing on the basis of protecting state secrets. ${ }^{279}$ Passaro claimed that the Bush Administration was classifying everything, and that the judge did not know any better than to deny requests to documents that the Bush Administration classified, which included decisive evidence. ${ }^{280}$ Likewise, Corporal Charles Graner was convicted for his role in the Abu Ghraib atrocities, and Graner appealed on the basis that there was an order for a "suspension" of war crime laws for the American military, ${ }^{281}$ which does not seem illogical with today's knowledge of the loophole legal opinions that were issued by advisors. ${ }^{282}$

The state secrets doctrine has questionable legitimacy, ${ }^{283}$ particularly when government directives were implemented and there are questions of fact over whether those orders led to detainee deaths and severe abuse, but pertinent government documents are classified and treated as "secret" information. The state secrets privilege is a common law evidentiary privilege that allows the government to "block discovery in a lawsuit of any information that, if disclosed, would adversely affect national security," 284 but it should not routinely prevail over a criminal defendant's assertion to obtain classified materials unless the classified document's evidentiary value to the accused is "clearly negligible." 285 Nonetheless, both Passaro and Granier defended

279. Ryan P. Logan, Note, The Detainee Treatment Act of 2005: Embodying U.S. Values to Eliminate Detainee Abuse by Civilian Contractors and Bounty Hunters in Afghanistan and Iraq, 39 VAND. J. TRANSNAT'L L. 1605, 1635 (2006); Judge Denies Ex-CIA Contractor Access to Classified Documents, WRAL.com (Aug. 3, 2006), available at http://www.wral.com/news/local/story/1091970/ (last visited Nov. 19, 2013).

280. Logan, supra note 279, at 1633-34.

281. Dan Eggen \& Josh White, Administration Asserted a Terror Exception on Search and Seizure, WASH. PoST (Apr. 4, 2008), available at http://www.washingtonpost.com/wpdyn/content/article/2008/04/03/AR2008040304136.html (last visited Nov. 19, 2013).

282. Scott Horton, A Nuremberg Lesson, L.A. Times (Jan. 20, 2005), available at http://articles.latimes.com/2005/jan/20/opinion/oe-horton20 (last visited Nov. 19, 2013) (Gonzales stating that "the Geneva Convention was 'obsolete' when it came to the war on terror."). Abu Ghraib was in Iraq, but the directives that were issued for Iraq also did not effectively respect the Geneva Conventions. Bejesky, Abu Ghraib Convictions, supra note 19 , at 22-31.

283. Louis Fisher, In the Name of National Security: UnChecked Presidential Power AND THE ReYnolds CASE (2006); Amanda Frost, The State Secrets Privilege and Separation of Powers, 75 Fordham L. Rev. 1931, 1933 (2007) (contending that the state secret's doctrine weakens congressional and judicial oversight of the executive).

284. Ellsberg v. Mitchell, 709 F.2d 51, 56 (D.C. Cir. 1983); see Reynolds v. United States, 345 U.S. 1 (1953); see The Military and State Secrets Privilege: Protection for the National Security or Immunity for the Executive, 91 YALE L.J. 570 (1982).

285. United States v. Schneiderman, 106 F. Supp. 731, 736 (S.D. Cal. 1952) (citing Scher v. United States, 305 U.S. 251, 254 (1938)). 
by contending that they were acting on orders of superiors and both claims were rejected, with Passaro's claim being rejected specifically because the memos he wanted to introduce as evidence were classified and protected from disclosure under "national security." 286 By April 2008, 22 out of 24 civil cases of alleged abuse by civilian employees and contractors were dropped by the Justice Department, and they may have been dropped substantially due to the defenses advanced by legal advisors. $^{287}$ It appears that advisory memos were classified to protect the administration and diffuse attention from scandal.

\section{Using Secrecy to Hide Legal Advice}

Over two years after the invasion of Afghanistan, classified legal advisory memos periodically emerged. ${ }^{288}$ The Justice Department Office of Professional Responsibility later investigated and provided a rather astounding explanation, which was that there were very few recipients of the legal memoranda because of "the limited number of security clearances granted to review the materials," that "[t]his denial of clearances to individuals who routinely handle highly classified materials has never been explained satisfactorily," and that the denial "represented a departure from OLC's traditional practices of widely circulating drafts of important opinions for comment." "289 Professor Jack Goldsmith, the new head of the OLC after Bybee, acknowledged the secrecy and "limited readership" and stated that other departments, such as the State Department, were expected to object to the opinions. ${ }^{290}$

For example, when pressed about specific legal device, Gonzales explained that he renounced advice imparted in one of the memos and would review other opinions issued by the OLC (or "John Yoo"), but also mentioned that the document in question was not scheduled to be declassified until 2012. ${ }^{291}$ Another memo written by

286. United States v. Passaro, 577 F.3d 207, 220 (4th Cir. 2009) (noting that the trial court "admitted some of the evidence in full, admitted some in redacted form, and excluded some as irrelevant, cumulative, or corroborative," which was not an abuse of discretion).

287. Eggen \& White, supra note 281, at A04.

288. Michael Isikoff, Double Standards?, NewsweEk (May 21, 2004), available at http://www.democraticunderground.com/discuss/duboard.php?az=view_all\&address $=103 \times 5$ 2175 (last visited Nov. 19, 2013).

289. DEP'T OF JUSTICE, supra note 24, at 260.

290. GolDSMITH, supra note 243, at 167; Neil Kinkopf, Is it Better to be Loved or Feared? Some Thoughts on Lessons Learned From the Presidency of George W. Bush, 4 Duke J. CONST. LAW \& PUB. Pol'y 45, 46 (2009) (stating that "Administration officials deliberated only among themselves: not publicly and not with Congress").

291. Allen \& Schmidt, supra note 57, at A01. 
Yoo and dated March 14, 2003 was eighty-one pages and not declassified until March 31, 2008. ${ }^{292}$ In July 2011, Human Rights Watch noted that top officials should be investigated and prosecuted if evidence warrants it, but pointed out that a main impediment to gathering evidence is that much information, internal memoranda, directives, and advisory memos remained classified. ${ }^{293}$

With respect to the details of the authorized interrogation methods, Gonzales contended in written responses for his confirmation hearings for Attorney General that he could not reveal "exceptional" Top Secret interrogation standards or practices because disclosure "would fairly rapidly provide al-Qaeda with a road map concerning the interrogation that captured terrorists can expect to face and would enable al-Qaeda to improve its counter-interrogation training to match it."294 This was not a very compelling explanation because the general methods of interrogation had been known for decades and were denounced by the international community. ${ }^{295}$

Despite the fact that Bush and other top officials kept issuing orders for interrogation consistent with the legal advice, ${ }^{296}$ classifying memoranda, and facing criticism by claiming that interrogators were ordered to remain within U.S. law, Gonzales oddly explained: "I don't believe the President had access to any legal opinions from the

292. See van Aggelen, supra note 108 (referencing Memorandum from John Yoo, Deputy Assistant Att'y Gen., U.S. Dep't of Justice, to William J. Haynes II, Gen. Counsel of the Dep't of Def. (Mar. 14, 2003).

293. Human Rights Watch, supra note 12, at 2; Mark Mazzetti \& Scott Shane, Interrogation Memos Detail Harsh Tactics by the C.I.A., N.Y. Times (Apr. 16, 2009), available at http://www.nytimes.com/2009/04/17/us/politics/17detain.html?_r=0 (last visited Nov. 19, 2013) (announcing the release of four new "detailed memos describing brutal interrogation techniques"). Recent investigations assessed the professional and ethical conduct of the lawyers as licensed attorneys, but Yoo's attorneys responded that the State Bar of Pennsylvania, his state of licensure, has a four-year statute of limitations for the advice in question, which had already expired. Miguel A. Estrada of Gibson, Dunn \& Crutcher LLP, Response to the U.S. Department of Justice Office of Professional Responsibility Final Report, at 4 (July 29, 2009), available at http://graphics8.nytimes.com/packages/pdf/politics/20100220JUSTICE/20100220JUSTICEYooResponse.pdf (last visited Nov. 19, 2013).

294. Eric Lichtblau, Gonzales Says '02 Policy on Detainees Doesn't Bind CIA, N.Y. TIMES (Jan. 19, 2005), available at http://www.nytimes,com/2005/01/19/politics/19gonzales.html (last visited Nov. 19, 2013).

295. Bejesky, Utilitarian Rational Choice, supra note 3, at 405-11 (explaining that the details of the CIA's Kubark interrogation manual (1963) could have been downloaded from the Internet, the methods were in findings and holdings of the ECHR case involving British abuse of Irish detainees in Northern Ireland, and waterboarding had been known of and condemned as war crimes since World War II.); see supra Part III(F)(3)(5).

296. Bejesky, Abu Ghraib Convictions, supra note 19, at 22-30. 
Department of Justice. ${ }^{, 297}$ How could Bush and appointees possibly issue orders and publicly claim that those tasked with carrying out directives were not violating law if he was not privy to the content of the memos? ${ }^{298}$ The directives that were issued were considered illegal and unconstitutional to an overwhelming percentage of Americans, the legal profession, and the rest of the world, ${ }^{299}$ but the White House hid behind the advice of four attorneys who kept issuing opinions to each other, and top Bush Administration officials kept classifying the memos. These top officials hid behind select legal memos in the same manner that they hid behind "intelligence information" to make their claims to invade Iraq. ${ }^{300}$ The secrecy also caused chagrin for the U.S. military.

\section{Using Secrecy that Compromised Military Responsibilities}

The legal advice from Bush Administration lawyers placed the military in a precarious situation because military officials were also implementing directives and managing detention facilities, but military officials and attorneys were either substantially unaware of the legal advice that sanctioned levels of abuse or their objections were ignored. ${ }^{301}$ The Schlesinger Report, which studied interrogation and

297. Adam Liptak, Author of '02 Memo on Torture: Gentle Soul for a Harsh Topic, N.Y. TIMES (June 24, 2004), available at http://www.nytimes.com/2004/06/24/world/reachwar-legal-advice-author-02-memo-torture-gentle-soul-for-harshtopic.html?pagewanted=all\&src $=$ pm (last visited Nov. 19, 2013).

298. Steven R. Weisman \& Joel Brinkley, Rice Sees Iraq Training Progress But Offers No Schedule for Exit: Senate Democrats Confront Nominee at Hearing, N.Y. TIMES (Jan. 19 , 2005), available at http:/query.nytimes.com/gst/fullpage.html?res=9F05EEDB1338F93AA25752C0A9639C8 B63 (last visited Nov. 19, 2013) (noting that Secretary of State Condoleezza Rice explained that "the determination of whether interrogation techniques are consistent with our international obligations and American law are made by the Justice Department").

299. Bejesky, Pruning, supra note 4, at 823-29; see supra Part IV(A).

300. See generally Robert Bejesky, The SSCI Investigation of the Iraq War: Part II: Politicization of Intelligence, 40 S.U. L. REV. 243 (2013); Bejesky, Intelligence Information, supra note 176 , at $875-82$.

301. Graham, supra note 149 , at 77 (stating that "there was no extensive legal debate, even within the Pentagon, concerning these interrogation methods," and that "[m]any, if not most, attorneys within the building were completely unaware that these methods had been approved"); Victor Hansen, A Response to the Perceived Crisis in Civil-Military Relations, 50 S. TEX. L. REV. 617, 638 (2009) (a small circle of advisors shut JAGs out of the process). Rear Admiral Don Guter, a former Navy JAG officer, explained that "[i]f we-we being the uniformed lawyers - that is, the lawyers who are in the U.S. military-had been listened to and what we said put into practice, then these abuses would not have occurred." Senator Harry Reid, Minority Leader, U.S. Senate, Statement on Nomination of Alberto Gonzales (Feb. 3, 2005), available at http://democrats.senate.gov/2005/02/03/reid-statement-on- 
detention abuse, states that the Secretary of Defense should have used "the legal resources of the Services' Judge Advocates and General Counsels" and obtained "a wider range of legal opinions and a more robust debate regarding detainee policy and operations." 302

Had the Bush Administration not hid legal advice as classified national security secrets, military attorneys may have had more of a reasonable opportunity to voice objections. However, a competing position is that JAG attorneys and the military generally did not need to be consulted and were not empowered to challenge the standards. ${ }^{303}$ Professors Yoo and Sulmasy wrote an article that challenged the contention that JAG attorneys should have provided legal counsel on detention and interrogation methods because doing so would have violated constitutional restrictions that ensure that there is civilian control over the military, enter JAG attorneys into domains in which they do not normally provide advice, and involve military lawyers in legal consultation when the "war on terror" was different from previous wars. $^{304}$

Yoo and Sulmasy's contention that JAG attorneys might cause a separation of powers dilemma by "resisting civilian policy choices" is theoretically reasonable, ${ }^{305}$ but JAG attorneys are also mandated by their professional obligations to impart advice on combat and related

nomination-of-alberto-gonzales/ (last visited Nov. 13, 2013). There was some high-level military consideration because Navy General Counsel Alberto Mora expressed his concerns three times to Haynes during December 2002 and January 2003 and believed that interrogation techniques at Guantanamo Bay may be torture. SENATE ARMEd Services COMMITTEE, supra note 13, at xxi; SANDS, supra note 63, at 139-40 (noting that there were warnings). However, Haynes was one of the four prime legal advisers who issued opinions that were condemned by scholars.

302. SCHLESINGER, supra note 175 , at 36 .

303. In March 2003, a Department of Defense Working Group issued recommendations for interrogation and opined what level of abuse would constitute torture under international law. U.S. DEP'T OF DEF., supra note 197. The military was instructed to accept the legal standards set by the Attorney General's Office of Legal Counsel. Detention Policies and Military Justice: Hearing Before the S. Subcomm. on Personnel of the S. Comm. of Armed Services, 109th Cong. 15 (2005); U.S. DEP'T OF DEF., supra note 197, at 24 (noting that "in wartime, it is for the President alone to decide what methods to use to best prevail against the enemy"). Orders consistent with OLC advice were applied in Afghanistan and Iraq. FAY, supra note 206, at 24-25; MAJ. GEN. GEOFFrey MiLler, ASSESSMENT OF DOD COUNTERTERRORISM INTERROGATION AND DETENTION OPERATIONS IN IRAQ 2 (2003).

304. Glenn Sulmasy \& John Yoo, Challenges to Civilian Control of the Military: A Rational Choice Approach to the War on Terror, 54 UCLA L. REv. 1815, 1818-23, 1842-43 (2007); Hansen, supra note 301, at 639 (disagreeing with Sulmasy and Yoo and noting that the authors exhibit a lack of understanding over the U.S. Constitutional structure).

305. Sulmasy \& Yoo, supra note 304, at 1834. 
concerns to commanders on a regular basis ${ }^{306}$ and avert military personnel from violating criminal laws. ${ }^{307}$ Foremost consternation arose over whether to extend Geneva Convention Prisoner of War protections to detainees, such as for alleged members of the Taliban and al-Qaeda ${ }^{308}$ and whether crimes under the Uniform Code of Military Justice were committed, such as murder, manslaughter, maltreatment, battery, and assault. ${ }^{309}$

In the capacity of legal advisor, there is no need to be overlyrestrictive $^{310}$ and oppose the government's preference, assuming the legal advisor offers reasonable advice. ${ }^{311}$ Perhaps there is a threshold

306. Laura Dickinson, Military Lawyers, Private Contractors, and the Problem of International Law Compliance, 42 N.Y.U. J. INT'L L. \& POL. 355 (2010) (article devoted to discussions with JAG attorneys and depicting that they are consulted daily on numerous legal issues relating to combat and operations); Sulmasy \& Yoo, supra note 304, at 1835-36 (stating that there are elevated concerns for legal doctrine during combat).

307. U.S. DeP't of ARMY, Regulation 27-26, Rules of Professional ConduCt FOR LAWYERS, R. 1.13(c) (1992), available at http://www.army.mil/usapa/epubs/pdf/r27_26.pdf (last visited Nov. 13, 2013) ("If a lawyer for the Army knows that an officer . . . is engaged in action, intends to act or refuses to act in a matter related to the representation that is either a violation of a legal obligation to the Army or a violation of law which reasonably might be imputed to the Army the lawyer shall proceed as is reasonably necessary in the best interest of the Army."); Kramer \& Schmitt, supra note 228, at 1426.

308. Jennifer Elsea, Treatment of "Battlefield Detainees" in the War on Terrorism, CRS REPORT FOR CONGRESS, at summary (Jan. 13, 2005), available at http://www.law.umaryland.edu/marshall/crsreports/crsdocuments/RL3136701132005.pdf (last visited Mar. 21, 2014) (stating that foreigners and human rights organizations have been especially critical of the denial of POW status to all combatants and that "[t]he publication of executive branch memoranda document[ed] the internal debate about the status of prisoners").

309. 10 U.S.C. $\S \S 893,918,919,928$ (2010).

310. John Yoo, A Crucial Look at Torture Law, L.A. TIMES (July 6, 2004), available at http://articles.latimes.com/2004/jul/06/opinion/oe-yoo6 (last visited Nov. 13, 2013) (“A lawyer must not read the law to be more restrictive than it is just to satisfy his own moral goals, to prevent diplomatic backlash or to advance the cause of international human rights law."). With respect to reciprocal obligations among states, such as to fulfill human rights standards that are binding on all governments, the Vienna Convention on the Law of Treaties provides that a treaty is to be interpreted "in good faith in accordance with the ordinary meaning to be given to the terms of the treaty in their context and in the light of its object and purpose." Vienna Convention on the Law of Treaties, Jan. 27, 1980, 1155 U.N.T.S. 331, art. 31(1). It does not say "treaties should be interpreted in light of every possible loophole, excuse, exception, and rationalization that can be conjured to avoid the object and purpose of the treaty." The Convention further states that the ordinary meaning of a treaty should be followed unless the meaning is "ambiguous or obscure" or "leads to a result which is manifestly absurd or unreasonable." Id. art. 32. It does not say that "a government should adopt manifestly absurd and unreasonable interpretations of human rights treaties to make the ordinary meaning of the treaty ambiguous or obscure." Id.

311. Barron \& Lederman, supra note 31, at 985-87, 998, 1006-07, 1015-17, 1031, $1037-38,1042,1044-45,1055,1059-60,1067-68,1075,1078,1083,1091$ (noting that the 
up to which advice should be assumed to be objective, but when opinions exceed this threshold of reasonableness with loopholes and technicalities that dismiss more orthodox interpretations of the law so to promote preferences of the government client, it seems highly probable that the advice could contort the view of the best interest of the ultimate client- the American public.

\section{CONCLUSIONS ON PATH DEPENDENCE}

This article maintains that human rights abuses might have been virtually inevitable as a path dependent outcome based on the Bush Administration's assumption of ubiquitous peril, open invitation to justify its policy preferences when it requested legal memos, and control over the national security apparatus. Several appointed legal advisers, who were prone to appease, ${ }^{312}$ produced advice with loopholes ${ }^{313}$ that contended the President has an all-puissant Commander in Chief authority that permits ignoring binding treaties and customary international law, that necessity and self-defense formed exigency to nullify laws that would otherwise restrict interrogations, that Afghanistan was a "failed state" without a lawful government, that distinctively classifying combatants and torture meant that detainees could be interrogated, and that the Taliban was more like a "militant, terrorist group" than a formal military. Effectively, the Bush Administration "construct[ed] a judicially-endorsed practice of permissible torture" $" 314$ and hid the advice that contended how directives would be legal. Ironically enough, the approach of hiding information

in the past, the Attorney General's office did impart diversity in opinions and did not always aggrandized executive war power).

312. Legal memos were written by OLC lawyers with "clear Republican credentials and affiliations," and those who reviewed the memoranda were "all Republican-appointed or at least Republican-affiliated officials." David Fontana, Government in Opposition, 119 YAle L.J. 548, 606 (2009); David Luban, Legal EThics AND Human Dignity 198 (2007) (calling the memos advocacy briefs rather than objective opinions).

313. David Weissbrodt \& Amy Bergquist, Extraordinary Rendition and the Humanitarian Law of War and Occupation, 47 VA. J. INT'L L. 295, 355 (2007) (opining that legal advisors intentionally produced "forward-leaning" memos to "see how far the CIA and the military could go without breaking the law, and how far the law could be stretched to move the line farther forward still"); Vanessa Blum, Culture of Yes: Signing Off on a Strategy, LEGAL TIMES, June 14, 2004, at 1 ("Guided by a determination to prevent another terrorist attack on U.S. soil, strong loyalty to the president, and in some cases an ideological disdain for international law, government attorneys sought ways to justify White House policies in the war on terror, much as a corporate lawyer might exploit loopholes in the tax code.").

314. David Luban, Liberalism, Torture, and the 'Ticking Bomb,' in THE TORTURE Debate In AMERICA 71 (Karen J. Greenberg, ed. 2006). 
in the national security apparatus, promoting a public agenda, and then using the national security apparatus as a scapegoat, was frightfully similar to the Bush Administration's false claims that led to the war in Iraq. ${ }^{315}$

The Bush Administration endowed American agents with a legal right to engage in the widespread use of interrogation methods that resulted in torture, kidnapping, unlawful detentions, and even deaths; ${ }^{316}$ knew of the abuse $;^{317}$ promoted legal advisors ${ }^{318}$ when they could have

315. Bejesky, Intelligence Information, supra note 176 , at $875-82$. In one specific piece of key information, the CIA Deputy Director of Intelligence requested analysts to write a "murky" paper to "lean far forward and do a speculative piece" and if you were to "stretch to the maximum the evidence you had, what could you come up with?" SELECT COMm. ON INTELligence, U.S. SENATE, RePORT ON THE U.S. INTELLIGENCE COMMUNiTy'S Prewar InTElligence AsSESSMENTS ON IRAQ, S. ReP. No. 108-301, at 306-07 (2004) (committee staff interview with CIA Deputy Director of Intelligence). The paper's scope note affirmed that it was "purposely aggressive in seeking to draw connections" and written for White House "senior policymaker interest in a comprehensive assessment of Iraqi links to al-Qa'ida." Id. at 305-07. Congressman Peter Hoekstra places blame on the intelligence hierarchy: "I think you've got a systemic problem here. I think the [intelligence] community is incompetent. It is arrogant... [I]t's become political." Transcript: Reps. Harman, Hoekstra on 'FNS', Fox NEwS (Dec. 16, 2007), available at http://www.foxnews.com/story/0,2933,317011,00.html (last visited Nov. 15, 2013). The Bush Administration regarded the information, much of it rumors, as serious in making threat claims to the American public. Robert Bejesky, The SSCI Investigation of the Iraq War: Part I: A Split Decision, 40 S.U. L. REv. 1, 37-38 (2012); Bejesky, Intelligence Information, supra note 176, at 859-63; Bejesky, CFP, supra note 110, at 22-29. The war may have cost American taxpayers upwards of $\$ 3$ trillion. See generally, JOSEPH E. Stiglitz \& Linda J. Bilmes, The Three Trillion Dollar War: The True Cost of The IRAQ CONFLICT (W. W. Norton \& Company ed., 2008).

316. ARNOVE, supra note 262, at 18-24; MCCOY, supra note 49, at 116; Bejesky, Pruning, supra note 4, at 823-36 (citing scholars contending that it is rather probable that the Bush Administration committed crimes).

317. Leila Nadya Sadat, International Legal Issues Surrounding the Mistreatment of Iraqi Detainees by American Forces, ASIL INSIGHTS (May 2004), available at http://www.tjsl.edu/slomansonb/AbuGhraib.pdf (last visited Nov. 15, 2013) (noting that abuses were generally known by top officials who could have prevented the abuses).

318. MCCOY, supra note 49, at 160 ("[The] Bush administration's torture advocates strut across television screens and down the corridors of power," operate above the law, and the chief architects and policy-makers of the memos that protect the torturers from criminal prosecution have almost all been promoted by Bush.); Diane Marie Amann, Application of the Constitution to Guantanamo Bay: Abu Ghraib, 153 U. PA. L. ReV. 2085, 2086 (2005) ("A few soldiers were prosecuted for detainee abuse, but generals implicated in government reports were not, and high-ranking civilians won promotion."). Bush appointed, and the Republican-controlled Congress confirmed Gonzales as attorney general after asking a few questions about interrogation memos. Senate Judiciary Committee, supra note 236. Bybee was also rewarded for "torturing the law" by being appointed a federal judge. Alvarez, supra note 47 , at 197 n. 83. 
been conspirators in war crimes; $;{ }^{319}$ and even responded to detainee attempts to attain legal redress as "lawfare" and international "judicial processes" that are "strategies of the weak" that undermine "[o]ur strength as a nation state." 320 Meanwhile, Yoo and Bybee acknowledged that interrogators would be relying on their advice, ${ }^{321}$ but it is highly unlikely that a prosecutor would indict when there is a Justice Department opinion that authorizes the practices, ${ }^{322}$ which can politicize the justice system. ${ }^{323}$

319. In THE NAME OF DEMOCRACY, supra note 17, at 133-35 (citing Marjorie Cohn, The Gonzales Indictment, MARJORIE COHN (Jan. 10, 2005), available at http://www.marjoriecohn.com/2005/01/gonzales-indictment.html (last visited Nov. 15, 2013)); David M. Brahms et al., An Open Letter to the Senate Judiciary Committee, Global SECURITY, available at http://www.globalsecurity.org/military/library/report/2005/senatejudiciary-committee-letter_03jan2005.htm (last visited Nov. 15, 2013) (a group of military officials expressing their concern about Gonzales's nomination because of his influence on supporting human rights violating interrogation and detention methods); van Aggelen, supra note 108 , at 22 .

320. U.S. Dep'T of Def., The National Defense Strategy of the United States of AMERICA $\quad 6 \quad$ (2005), available at http://www.defenselink.mil/news/Apr2005/d20050408strategy.pdf (last visited Nov. 15, 2013). The term "lawfare" was offered as a means of describing reliance on legal means to confront national security issues instead of by military force, and that the U.S. has traditionally relied on defensive lawfare. Orde F. Kittrie, Lawfare and U.S. National Security, 43 CASE W. ReS. J. INT'L L. 393, 394, 399, 401 (2010); DAVID KENNEDY, OF WAR AND LAW 116 (2006) ("Law now offers an institutional and doctrinal space for transforming the boundaries of war into strategic assets, as well as a vernacular for legitimating and denouncing what happens in war."). The fear is that an enemy could use the U.S.'s strong legal system against us. Fred K. Ford, Keeping Boumediene off the Battlefield: Examining Potential Implications of the Boumediene v. Bush Decision to the Conduct of the United States Military Operations, 30 PACE L. REV. 396, 401 (2010). Abused detainees could allegedly wage "lawfare" against the United States. Michael J. Frank, U.S. Military Courts and the War in Iraq, 39 VAND. J. TRANSNAT'L L. 645, 651 (2006) (noting that "[u]nfortunately, the United States has not fully taken advantage of and enjoyed the fruits that can be reaped from the prosecution of war criminals, particularly with respect to terrorists operating in the Iraqi theatre of operations" which "is due in part to the effects of the lawfare being waged against the United States with respect to the prisoners at Guantanamo Bay, Cuba").

321. The Torture Papers: The Road to Abu Ghraib 172 (Karen J. Greenberg \& Joshua L. Dratel ed., 2005) (referencing Memorandum from Jay S. Bybee, Assistant Attorney Gen, to Alberto R. Gonzales, Counsel to President (Aug. 1, 2002)).

322. Clarke, supra note 275, at 46; William E. Lee, Deep Background: Journalists, Sources, and the Perils of Leaking, 57 AM. U. L. REV. 1453, 1455-56 (2008) (noting that it was "extraordinary" that Gonzales claimed "that the government has the legal authority to prosecute journalists for publishing classified information," such as those related to torture and other scandals).

323. In another example, in late 2006, individuals at the Department of Justice forced out several prosecutors in an effort to "manipulate prosecutorial decisions in an effort to entrench their political allies;" but "[t]he White House, of course, denied any involvement." Eric Lane, Frederick A.O. Schwarz, Jr. \& Emily Berman, Too Big a Canon in the 
In April 2008, after legal memos were successively issued for six years, the Justice Department finally decided to commence an investigation into whether its officials were improperly advising Bush and top White House officials on issues related to international law, wartime authority, and laws governing torture. ${ }^{324}$ One month later, fifty-six members of Congress sent a letter to Attorney General Michael Mukasey, Bush's new appointee, to choose a special counsel to investigate whether top Bush Administration officials committed crimes by authorizing harsh interrogation techniques. ${ }^{325}$ It is difficult to cogitate what is left to investigate after years of assiduous work by the ACLU, numerous human rights groups, courageous dissenting officials, a dozen military investigations, and the Bush Administration's own admissions. ${ }^{326}$ Even former President Jimmy Carter expressed whether he believed that the Bush Administration issued policies that tortured prisoners in violation of international treaties, and he stated: "I don't think it. I know it." 327 With reference to the Bush Administration's contention that the "Geneva Convention do not apply to those people in Abu Ghraib prison and Guantanamo," Carter further explicated that the assertion seems to assume that "we can torture prisoners and deprive them of an accusation of a crime to which they are accused ... [Y] ou can make your own definition of human rights and say we don't violate them, and you can make your own definition of torture and say we don't violate them." 328

President's Arsenal: Another Look at United States v. Nixon, 17 GeO. MaSON L. REv. 737, 770 (2010). Congressional investigations revealed that White House officials did play an active role in the firings, and there was "politicization of the American criminal justice system." Id. at $770-71$.

324. Lara Jakes Jordan, Justice Department Investigating 2003 Torture Memo, Associated PRESS (Apr. 17, 2008), available at http://www.chron.com/news/nationworld/article/Justice-Department-investigating-2003-torture-memo-1647622.php (last visited Nov. 15, 2013).

325. John Conyers, JR., Reining in the Imperial Presidency: Lessons and Recommendations Relating to the Presidency of George W. Bush 368 n.531 (2009) (citing Letter from Jan Schakowsky, Rep., U.S. House of Rep., et al., to Michael Mukasey, United States' Attorney General (June 6, 2008).

326. Bejesky, Abu Ghraib Convictions, supra note 19, at 19-22, 64-75.

327. Carter Says US Tortures Prisoners, CNN (Oct. 10, 2007), available at http://www.cnn.com/2007/POLITICS/10/10/carter.torture/ (last visited Nov. 15, 2013).

328. Id. 